United States Department of Agriculture Burear of Entomolog and Plant Quarantine

Agricultural Research Administration

$\triangle$ DIGEST OF INFORMATION ON CHLORDANE

By

R. C. Roark

Division of Insecticide Investigations 
Page No.

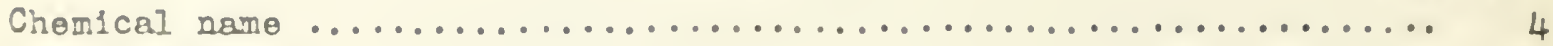

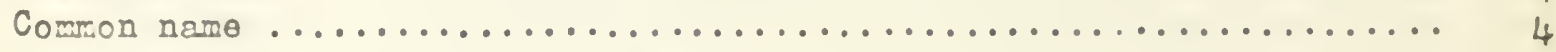

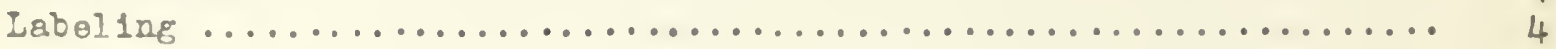

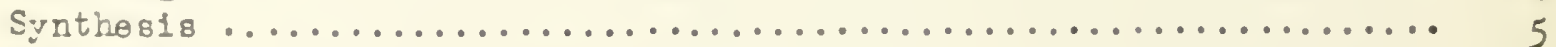

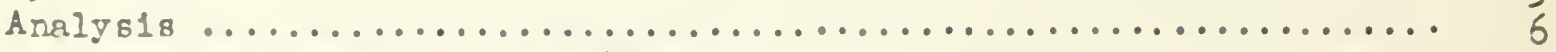

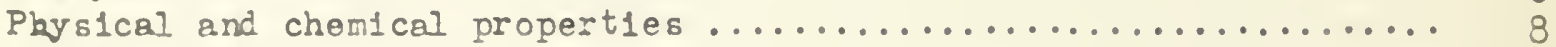

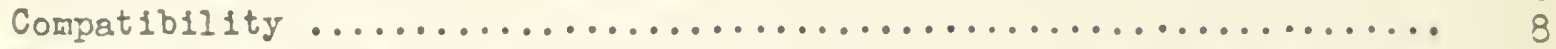

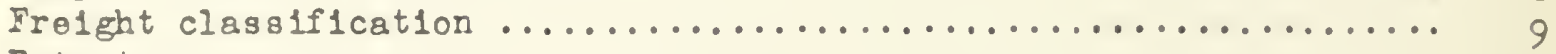

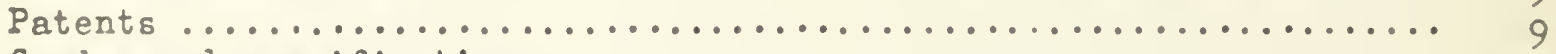

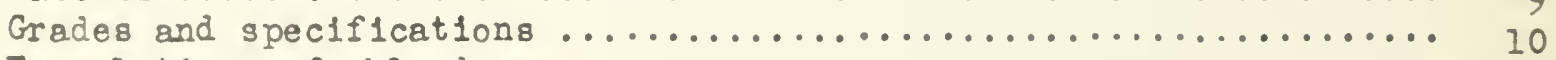

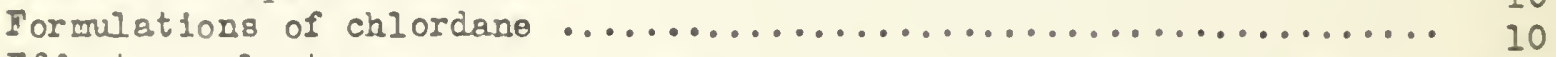

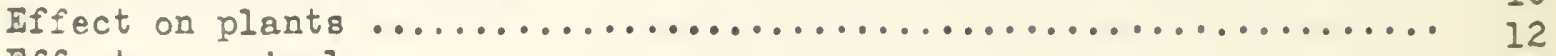

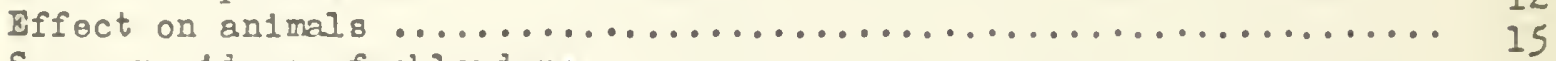

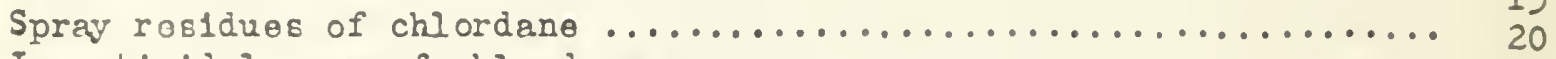

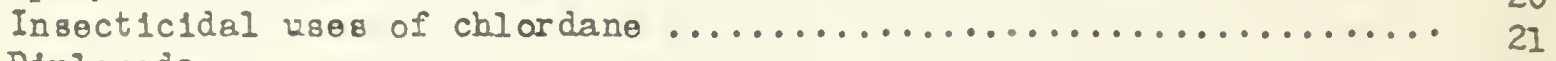

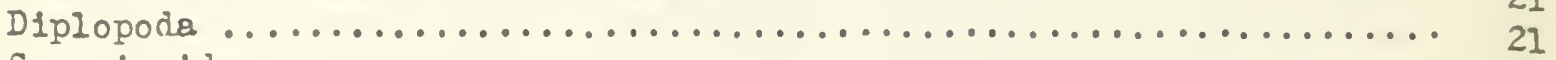

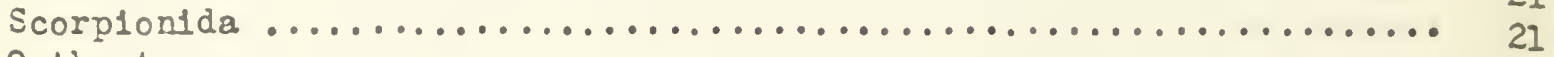

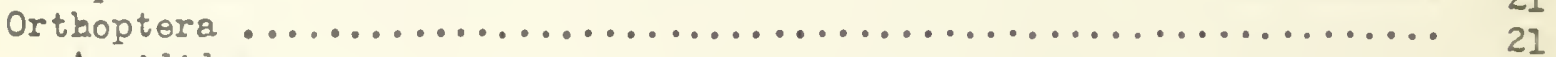

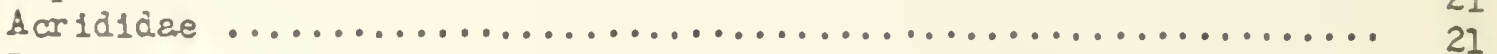

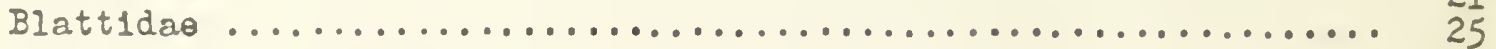

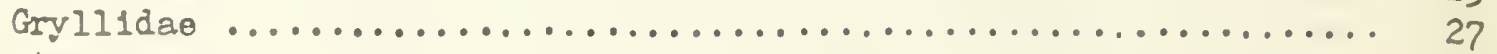

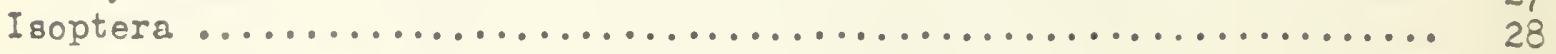

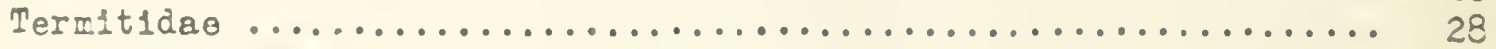

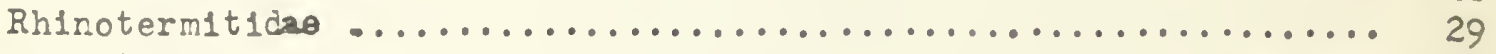

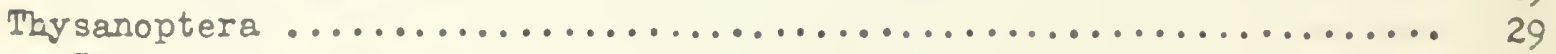

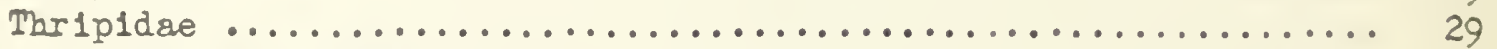

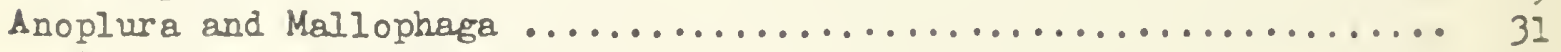

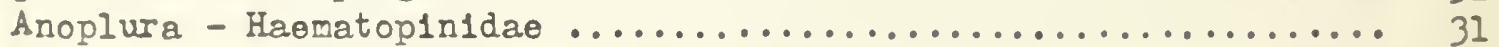

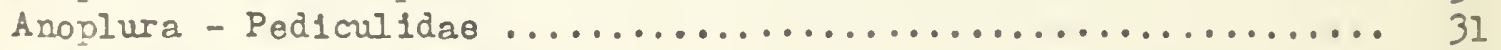

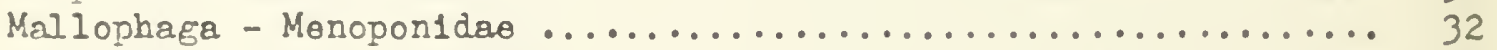

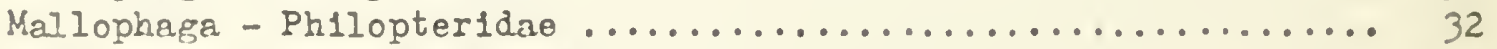

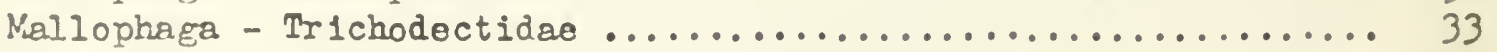

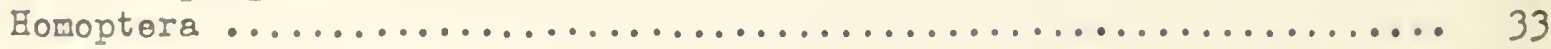

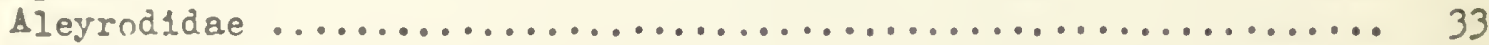

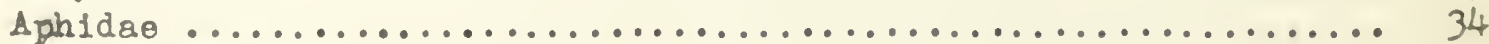

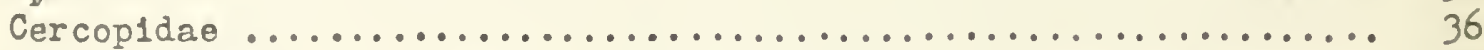

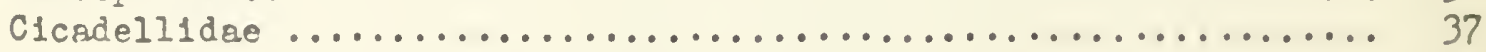

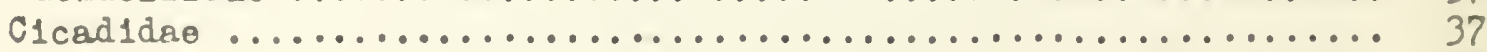

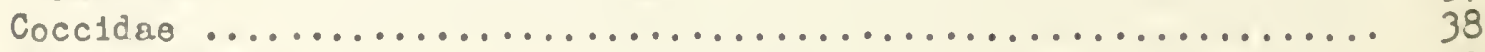

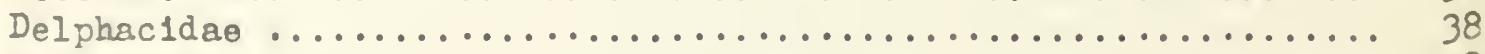

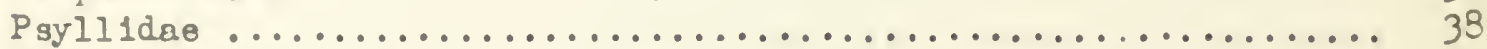

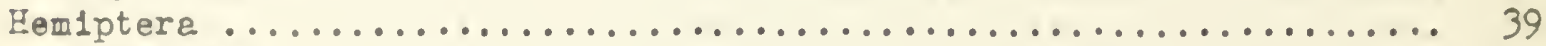

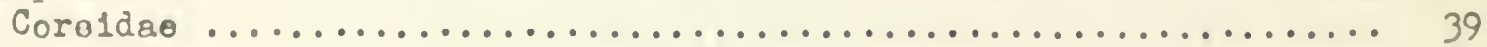

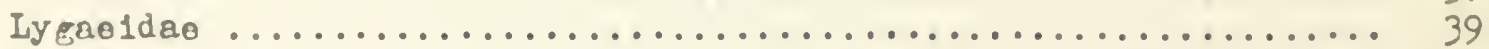

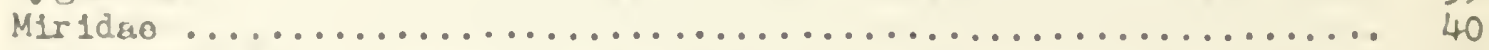

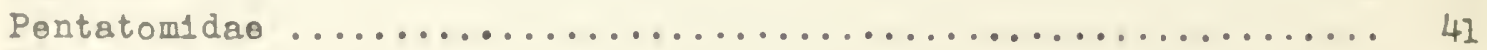

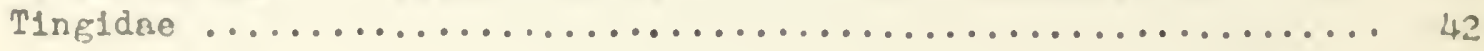




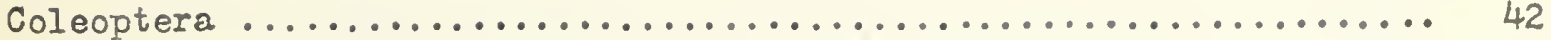

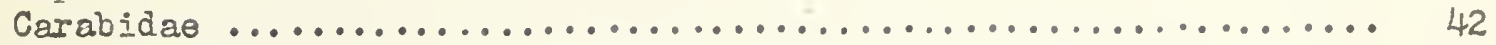

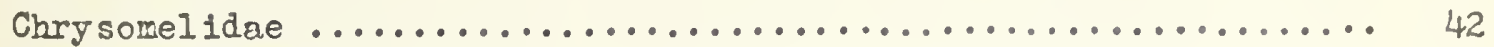

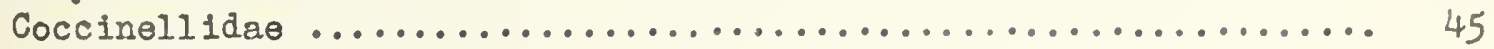

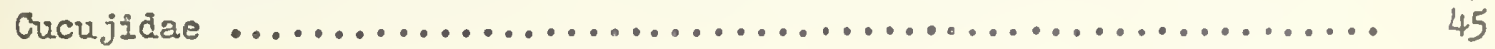

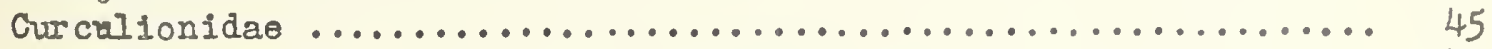

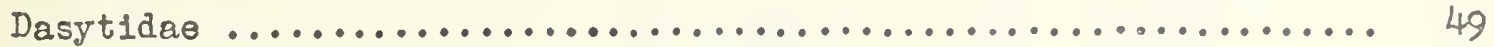

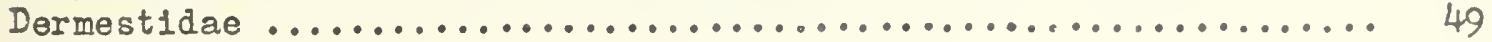

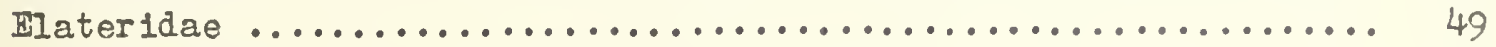

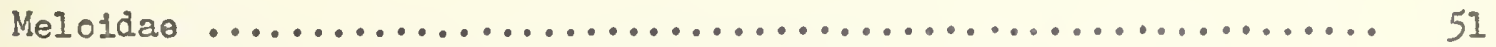

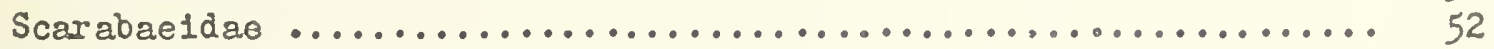

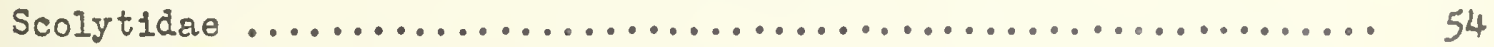

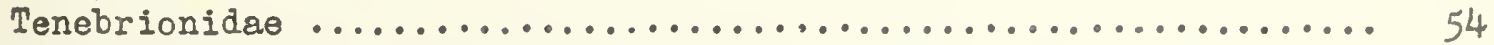

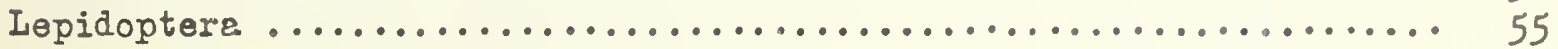

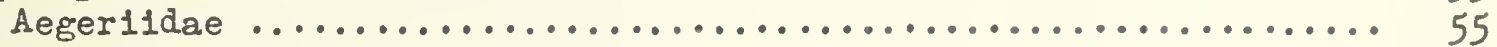

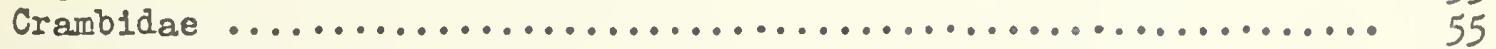

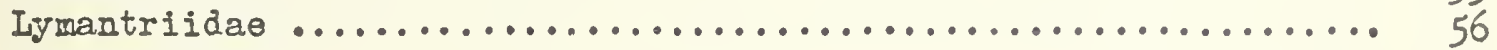

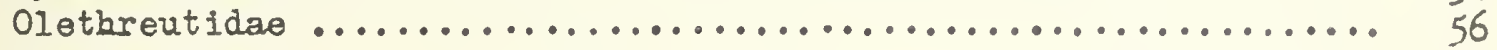

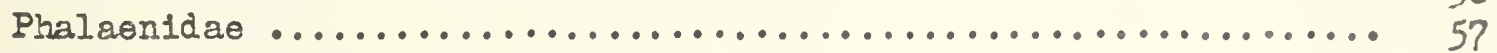

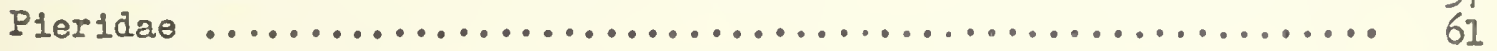

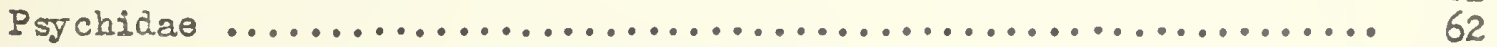

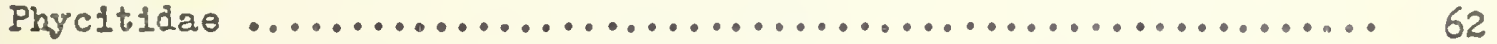

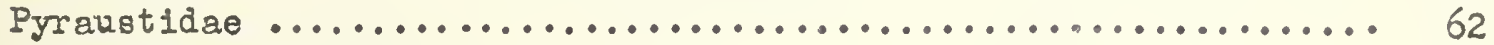

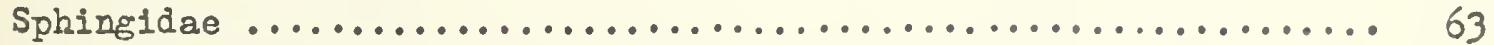

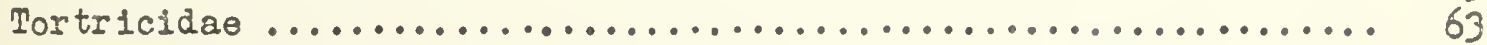

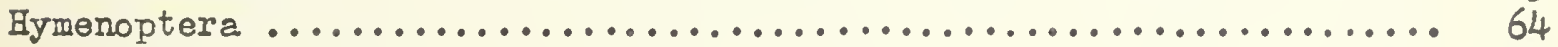

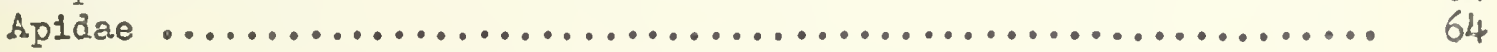

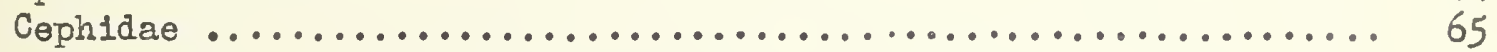

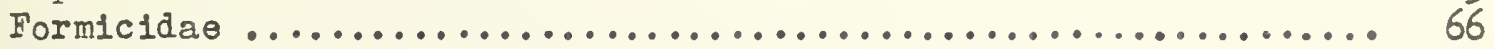

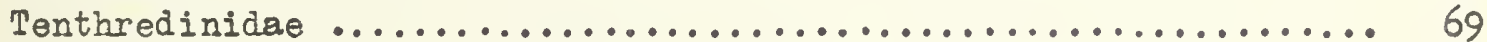

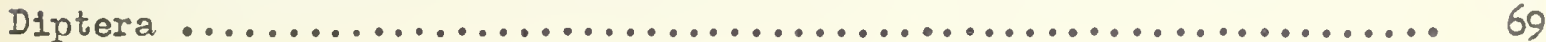

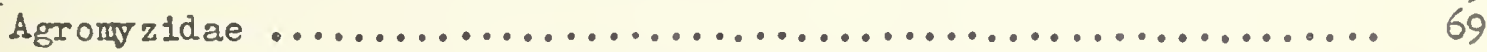

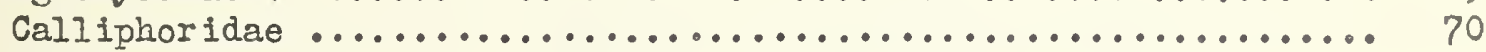

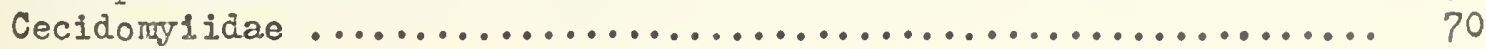

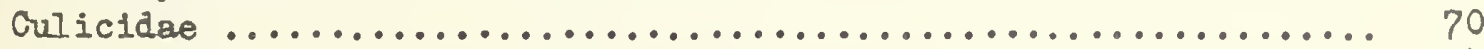

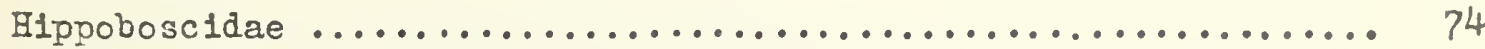

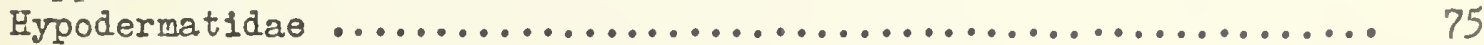

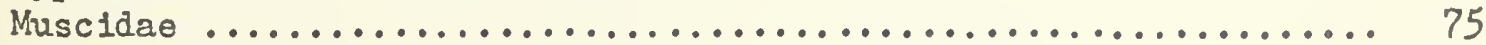

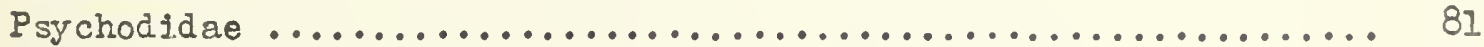

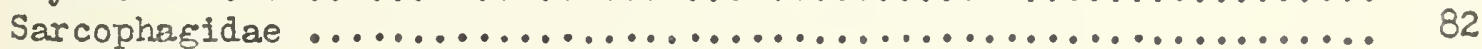

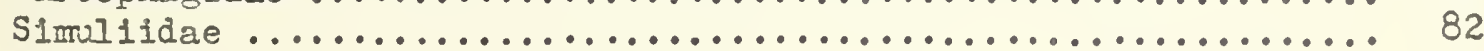

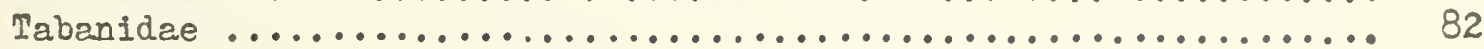

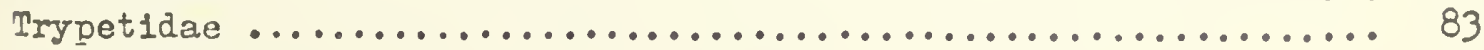

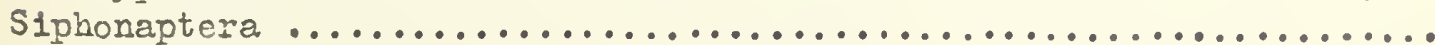

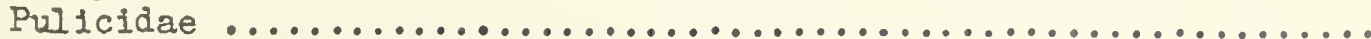

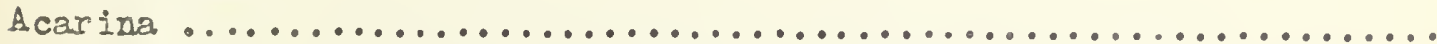

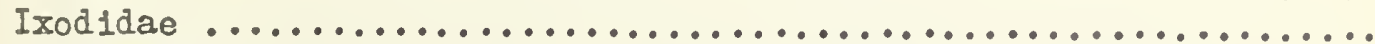

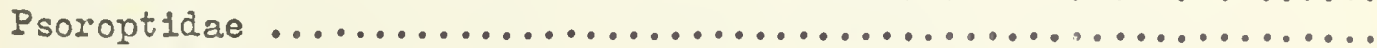

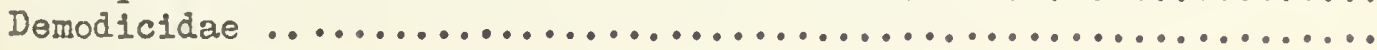

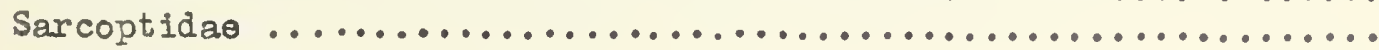

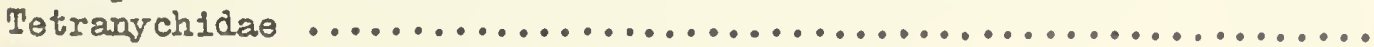

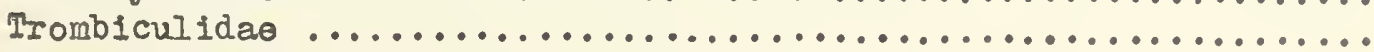

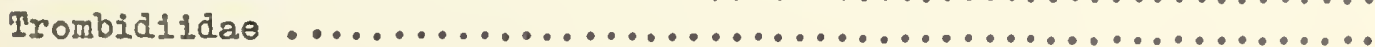

Itterature cited 
The 11rst announcoment of the now insect1cide now known as chlordano appeared in the December 194518 sive of the Journal of Econonic Entomolog. In an erticlo by Koarns et al. (245) ont1tlod "A Nov Culorinsted Eydrocarbon Insecticlde" attention was called to a poduct having the explrical formule $\mathrm{C}_{1} \mathrm{OH}_{6} \mathrm{Ol}_{8}$ which had been found to be more tox'c than DDI and to compere 18vorably in toxiclty to the pure ganma 1somer of bonzone bexachlorlde to several specles of 1nsects. The compound, called 1068, ves stated to bo possibly a mixture of 1 somers.

\section{CBRMICAL NAME}

In the 1947 subject index of Cherical Abstracts chlordane 1 a called $1,2,4,5,6,7,8,8$-octachlor $0-2,3,3 a, 4,7,7$ a-hexabydro-4, 7-aetharoindene. In certaln publications the name 1,2,4,5,6,7,8,8-octacbloro-4, 7-metbano$3 a, 4,7,7 a-t e t r a h y d r o 1 n d a n e$ has been usod. [indan 1s 2,3-cithydroindene]. Britigh patent No. 518,432 refors to tho compound as octachlorodicyclopentadiened i hydride.

\section{COMMON INAICE}

The selection of the nare "chlordano" for this chemical was announced on February 25, 1947, followl ne conferences of represertatives of the Bureau of Entomology and Plant Quarantine, tho Production and Marketing Administration, the Food and Drug Administration, and tho compan1es producing this insecticide. The name "technical chlordane" was proposed for the "comercially produced chemical containing 60 to 75 percent of chlordane, together with 25 to 40 parcent of relatod coupounds, occurrine in the normal mamuacturing processes, which are toxic to 1nsects." The names "chlordane" and "technical chlordane" were recorded 1n the Patent Office as of February $27,1947$.

Murpiny (241) pointed out that the terminal "ane" in chlordano is misdescript1ve as it 18 properly reserved for saturated hrdrocarbons and parent heterocyclic compounds. Chomlcal Abstracts and tho other journals of the American Chemical Soclety refer to this compound 28 "chlordan", bat the United States Department of Agriculture and industry call it "chlordane".

\section{IABELING}

For the purpose of laboling Insecticldes under the now Foderal Insect1c1de, Fungiclde, and Rodenticide Act, the Production and MarletIng Adminlstration of the United States Department of Agriculture bas approved the use of tho ahortened namo - octachloro-4,7-mothanotetrahydrolndano. 
It has further ruled that "Technical chlordane is the comercial product containing 60 percent to 75 percent of chlordane togetier with 25 percent to 40 percent of ther related compounds, nor mally resulting from the manufacturing processes, and toxic to certain insects. All of its ingredients are, therefore, considered active under the Insecticide Act."

\section{STNTHESIS}

The syntizesis of chlordane is described in patents granted Hyman (232, 233). It is made by combining hexachlorocyclopentadiene and cyclopentadiene to form a Dielsalder addition product of the formula $\mathrm{C}_{10} \mathrm{H}_{6} \mathrm{Cl}_{6}$, to which chlorine is added to form $\mathrm{G}_{10} \mathrm{H}_{6} \mathrm{Cl} 8$.

The reaction is as followg:
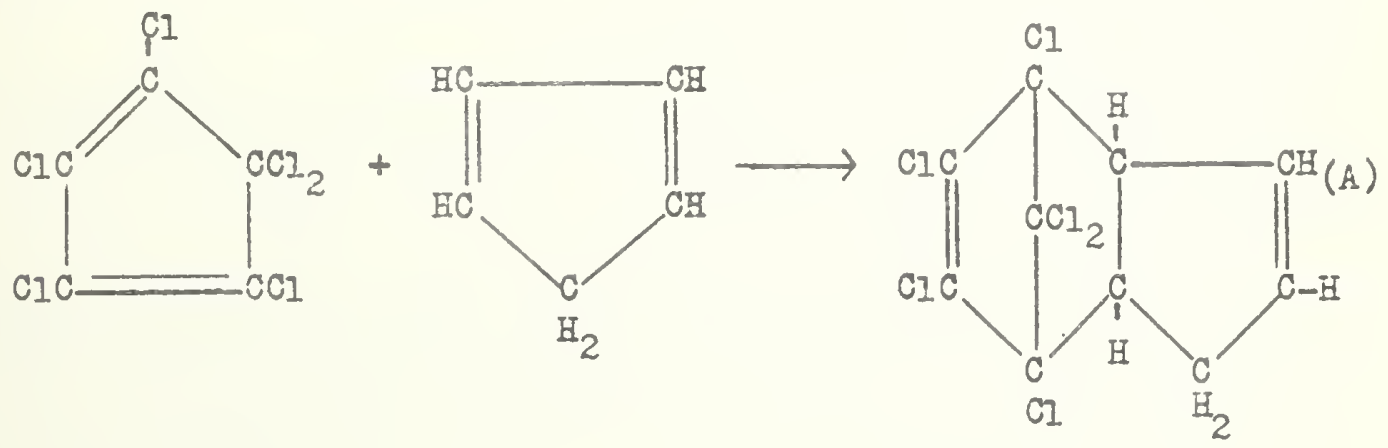

The adduct is dissolved in carbon tetrachloride and treated with chlorine gas with the resultant addition of two atoms of chlorine to the double bond (A) to form chlorane:

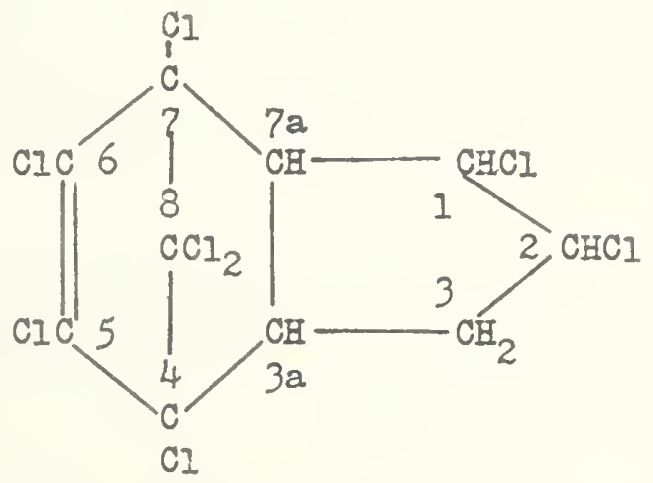

It is of interest to know that Riemschneider and Kuhnl (389) in Germany claim to have independently discovered the insecticidal properties of chloràne. They were led to prepare it from its structural analogy to cantharidin which they state is a contact insecticide. The structure of cantharidin 1s: 


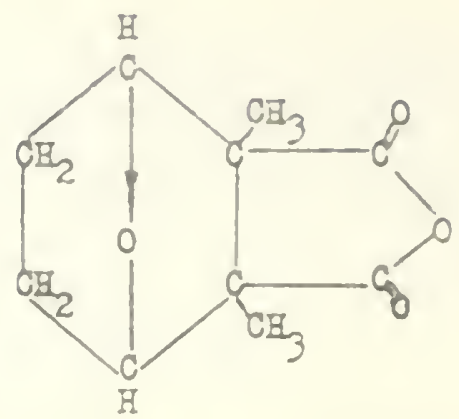

One of the insecticides developed by Blemschnelder and Tuhal, called M-4I0, Is stated to hare the same stractural farmula as that assignod to chlardane. Ho detalls are givon regarding its synthosis or act1on on insects but $1 t$ is clalmed to be no more toxic than DDT to nice.

\section{ANALYSIS}

Ther are no specific chemical and physical mothod for deternining cblordano.

Ard (22) has describod a qual1tat17e test for chlordane in 1nsect1c1de spras 0118. The method consists in mixing $1 \mathrm{ml}$. of tho sarplo in a test trbe with $2 \mathrm{ml}$. of a Cellosolve-pyridine $(40: 10)$ solut1on and $1 \mathrm{~m}$. of an approximately I IN solution of potessium hydroxide in 95 percent ethyl alcohol. When boatod in a boll1ng water beth with occaslonal og1tation for 5 minutes, the appearance of a red color indicates the presence of chlordane. A I-ml. sample of $0.2 \%$ chlordano in a deodorized kerosene base gives a wine-red color of considerable strength, and 1 percent gives an intense dark red color. Very veak colors sbould be regarded as possibly due to other substances. A conflrmatory test for chlordane is the appearance of an odor resembl1ng that of a crude methrlapphthaleno whod tho sample is dohalogenated with sod1um in boll1ng 1sopropyl alcohol as is done in the determination of total chlorino. Toxaphone is the only other insecticide that yleld a similar odor when sujjected to this test.

Some chemista using Ard's mothod have polnted out that the red color developed is due to by-products in the technical grade of chlordene and that pure chlordane does not give th1s color. The method vould appear to be applicable, howerer, if the anount of color-producing materials vere a constant in the commercial product.

Alossandrin1 (10) modifled Ard's metiod by subst1tut1ng etrylono glycol for Collosolve (the monoethyl ether of ethylene glycol). The coloration prodaced 18 loss intenso than in tho or 1 final method. The presenco of DDT does not interfere with the coloration.

Analyses of chlordano formations by th1s method and by the determination of total and labile chlarino have boon publishod by Alessandrint and Amormino (11). 
Another colorimetric method for the identification and determination of chlordane specifies that $1 \mathrm{ml}$. of a 0.1 - 1.0 percent solution of chlordane in ethanol bo mixed with 1 ml. N potassium hydroxide in ethanol and $1 \mathrm{ml}$. of a reagent prepared by dissolving 0.1 gram of p-aminophenol in $100 \mathrm{ml}$. of 80 percent ethanol. When heated to $100^{\circ} \mathrm{C}$. for 5 to 10 minutes, the appearance of a blue color indicates the presence of $1 \mathrm{mg}$. or more of chlordano. None of tho other common insecticides interferes.Palumbo (355).

In the laboratories of the Division of Insecticide Invest1gations, Bureau of Bntowology and Plant Quarantine, the total chlorine in chlordano is determined by decomposing tho sample with sodium in refluxtng anhydrous isopropyl alcohol and titrating the sodiun chloride formed with $\mathrm{N} / 10$ silver nitrate solution, using an electrometric titrimeter. Chlordane is calculated by maltiplying the total organic chlorine content by $1.44, a$ factor based on the fact that pure chlordane contains 69.22 percent of chlorine.

Romano (398) has pointed out that temperature, concentration of chlordane in solvent, and ratio of potassium hydroride to solvent influence the dehydrohalogenation of chlordane and that a carefully standardized method is necessary in order to obtain reprocucible results. Romano refluxes a solution of a 0.5 gram of chlordane in $20 \mathrm{ml}$. of petroleum ether with $20 \mathrm{ml}$. of $\mathrm{N}$ alcoholic potassium hydroxide at $80^{\circ} \mathrm{C}$. for 30 minutes and determines the chloride by Volhard's method; $1 \mathrm{ml}$. $0.1 \mathrm{H}$ silver nitrate $=47.6 \mathrm{mg}$. chlordane. This factor used by Romano is an arbitrary one. The loss of one chlorine atom from the molecule of chlordane, $\mathrm{C}_{10} \mathrm{H}_{6} \mathrm{Cl}_{8}$, calis for the value $1 \mathrm{ml}$. $0.1 \mathrm{~N}$ silver nitrate = $40.8 \mathrm{mg}$. chlordane.

Davidow (28) In 1950 described a spectrophotometric method for the quantitative estimation of technlcal chlordane which is also applicable to the estimation of alpha-chlordane, beta-chlordane, hoptachlor, and trichloro 237 (all present in technical chlordane) when only one is present. The procedure is to develop a colored reaction product by heating chlordane in n-hexane with diethanolamine-potassium hydroxide reagent in a bolling water bath for 30 minutes and note the absorbency at 521 millimicrons in a Beckman spectrophotometer.

Technical chlordane interferes in the method for the determination of heptachlor in which equal volumes of the suspect solution and a 0.5 molar solution of ethanolamine and of potassium hydroxide in butyl Cellosolve are mixed and heated in a boiling water bath for 15 minutes, the development of a pink to deep violet indicating the presence of heptachlor.--Velsicol Corp. (479).

Chlordane does not interfere in the colorimetric estimation of aldrin in which the aldrin is reacted with phenylazide to form a dihydrotriazole derivative which yields an intense red color when reacted with diazotized dinitroaniline in alcoholic hydrochloric acid.-Danish and Iidor (22). 


\section{PEYSICAI AMD CHEAICAL PROPERTIES}

Chlordane is a viscous, amber colored, nearly odorless liquid, boiling at $175^{\circ} \mathrm{C}$. at $2 \mathrm{~mm}$. pressure. It is insoluble in water and soluble in organic solvents such as aliphat1c, aromatic, and chlorinated hydrocarbons, as well as in ketones, esters, and ethers. It is completely miscible in all proportions with deodorized kerosene, a solvent widely used for insecticidal products.- Kearns et al. (245); Sun (446); West (496). Its specific graritg range is $1 . \overline{60}-1.535$ at $60^{\circ} \mathrm{F} . / 60^{\circ} \mathrm{F}$. equivalent to a welght per gallon of approximately 13.3-13.6 pounds. The refractive index is 1.56-1.57 at $25^{\circ} \mathrm{C}$.--Bussart and Schar (59).

It has been reported that $\nabla$ an Dyk 264 (li-octyl-b1cyclo[2.2.1]-5heptene-2,3-d1earboximide), a synergist for pyrethrins, w1ll dissolve 50 percent of its weight of chlordano.-Anon. (3).

Chlordane dehydrobalogenates in the presence of alkalino reagents with concomitant loss of insecticidal activity. Far this reason, it should not be formulated with alkaline solvents, carriers, or emalsifiers.

\section{COMPATIBILITY}

Frear (155) has published a table showing the compatibility of the common spray materials. Chlordane is represented as follovi:

\begin{tabular}{l} 
Chlordane mixed with: \\
\hline Lead arsenate \\
Calcium arsenate \\
Paris green \\
Cryolite \\
Rotentone \\
Pyrethrum \\
Nicotine \\
DDT \\
BHC \\
Toxaphene \\
ThPP \\
Parathion \\
Sumer o1ls \\
Dormnt o1lo \\
Din1tro compounds \\
Lime sulfur \\
Wettable sulfur \\
Ilme \\
Fixod coppers \\
Bordoaux \\
Dithiocarbarates
\end{tabular}

Compatibility

Fully compatible

Compatibility questionable

Fuliy compatible

Cryolite

Rotentone

Pyrethrum

Nicotine

DDT

$\mathrm{BHC}$

Toxaphene

Summer o1ls

Dormat o118

Dinitro compounds

Lime sulfur

Wettable sulfur

IIme

Fixod copper

Dithiocarbaratos

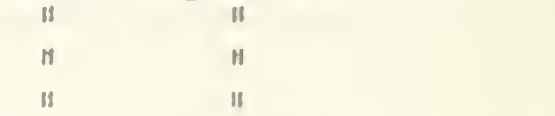

Compat1b111ty questionable Fully compatible

$\begin{array}{ll}\text { " } & \text { " } \\ \text { " } & \text { " } \\ \text { " } & \text { " } \\ \text { " } & \text { " }\end{array}$

Compat1bility questionable Fully compat1ble

Compatibility questionable

Fuly compatible

Compatiblilty questionable

Furily comortiblo

Chartg showing the compatibility of chlordano with other insect1cides were publiohed anonymourly $(1,5)$ in the February 1948 and 1949 1ssues of the American Fruit Growor. Chlordano 1 s representod as doubt- 
ful with basic lead arsenate, calcium arsenate, 40 percent nicotine, Bordeaux, glyoralidines, lime sulfur, zlnc sulfate plus lime, and Iimo; and compatible with all other insecticides and fungicides.

A mixture of chlardane 50-percent wettable powder w1th 4-8-8 fert1lizer at the rate of 2 pounds to 1000 maintained insect1cidal activity for at least 30 days.-- Kelsheimer (252). Chlordane in certain fertilizer mixtures remalned active for 192 days.-Compton (22).

Additional observations on the compatibility of chlordane with epray materials have been recorded by Marshall (316); and Griffiths and Bing (192).

The American Fruit Grower (Anon. 4, 6) has published charts showing the weather factors in spraying and dusting fruits with insecticides. Chlordane is Iisted as safe to apply to both pome and stone frults under 5 weather conditions: temperature above $85^{\circ}$; temperature 850 to $65^{\circ}$; temperature $65^{\circ}$ to $40^{\circ}$; light rain; high humidity with slow drying.

\section{FREIGHT CLASSIFICATION}

Beginning June 1, 1948 chlordane was shipped under a new item "Polychlor Agricultural Insecticides and Fungicides" in tho consolidated freight classification.

Polychlor is a name selected by the Classification Committer for a group of compounds, including DDT, benzene hexachloride, toxaphene, and chlordane which contain three or more chlorine atoms. This name is used only for shipping purposes, not for labeling. It was selected to aroid confusion among carriers as well as shippers over the long chemical names of this group of products, whose importance is increasing, and to aroid numerous requests for exceptions for individual products. AII itemg in this group now will enjoy the same freight classification in their territory. Shippers should note that this new item does not cover the technical chomicals which should still be described as "chemicals, noibn"; Iikewise, it does not cover liquid preparations, or dry formulations in excess of 50 percent of the chlorinated chemical. Such formulations will continue to be described as "insecticides or fungicides, noibn". Anon. (2).

\section{PATENTS} follow:

Patents on chlordane have been granted Julius Eyman (231-233) as

Belgium - Patent No. 464,617 granted April 16, 1946.

Fngland - Patent No. 618,432 granted February 22, 1949.

Mexico - Patent No. 45,398 granted March 19, 1947.

United States - Patent No. 2,519,190 granted August 15, 1950. 
The process disclosed in those patents 18 discussed under the boed1 Ig "Synthes1s" on page 5.

The adduct $\mathrm{C}_{10} \mathrm{H}_{6} \mathrm{Cl}_{6}$ formed by combining hexachl ar ocyclopentadieno and cyclopentadiene in the flrst atep of making chlordane has some 1nsect1cidal properties. Th1s compound, called chlorcono, has been patented for use as an 1nsecticide by tho Vels1col Corporation (475427) and der18at1ves of 1t, for example, 1-kydroxy cblordone, 1,2dihydroxy chlordene, and I-acyloxy chlordeno have been patented by Herzfeld et al. (213-215) assl gnors to the Velsicol Corporation.

\section{GRADES A.D SPECIFICAMIONS}

There 18 only ono manufacturer of chlordane, the Velsicol Corporat1on, 330 East Grand Arenue, Ch1cago 11, Ill1no1s, which calls 1ts product "Vels1col 1068". Jul1us Hyman \& Company, Denver, Colorado, for verly made chlordane which was aold under the trade rame "Octa-Ilor". On May 29, 1950 the United States Supreme Court refused to review the case of Jul 1ur Hyman, thus maklng effect1ve \& decree affirmed by tho Supremo Court of Illinois which enjolng Julius Byman \& Compang from making and selling chlordane.

The technical chlordano (AG grade) manufactured by the Velsicol Corporation (478) complies with the following specifications:

\section{Property}

Spec1f1c gravity at $60^{\circ}$ F./60 $\mathrm{F}$. Weight per gallon ( $1 \mathrm{bs.)}$

Color (Gurdner-Fell1ge-1933)

V18cosity (cent1stokes at $130^{\circ}$ F.)

V1scosity (SSU at $130^{\circ} \mathrm{F}$. )

Total chlorine content (\%)

Insolubles in deodorlzed keroseno at $20 \% \mathrm{~V} / \mathrm{V}$

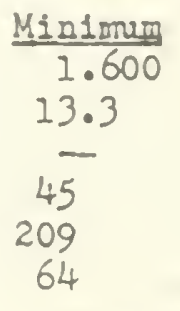

$-$ $\frac{\text { Nex1mum }}{1.635}$
13.6
14
70
324
66
None

The clarifled grade is I1ghter in color than the AG grade, othern'ise, 1ts properties are tho same.

\section{FORMULATICIS OF CELORDANE}

The manufacturer of chlordane, the Velsicol Corporation, has 1ssued several publications giving detalled directions for the preparation of chlordane formulations and these publications should be conaulted by those intending to make a chlordane insecticide.

Chlorlane is commonly employed in the form of solutions, emulsions, dusts, and wettable powdors. Ilquefled gas aerosols of chlordane have been tosted and found to yleld promising resulta. 
Solutions of chlordane are easily prepared as it is readily soluble in the common organic solvents. It is miscible in all proportions with kerosene.

Emulsions containing chlordane can be formulated with or without a solvent (Mail, 311, 312). This is because chlordane is a liquid. The addition of small amounts of oil-soluble emulsifiers to oil solutions of chlordane makes emulsion concentrates which may be added to any desired amount of water. Also chlordane may be emalsified directly in water by the addition of a soluble emulsifier; however, in this case higher percentages of emulsifier must be used in order to maintain the same cream separation rate as that shown by aqueous emulsions made from oll-containing concentrates.

Twenty-two emulsifiers suitable for emulsifying a kerosene solution of chlordane in water are listed by Lidor et al. (298). An emulsifiable concentrate that produces a moderately stable emulsion is made by dissolving 1 pound of chlordane and 5 ounces of Atlox $1045 \mathrm{~A}$ (polyoxyethylene sorbitol oleate-laurate) in sufficient kerosene to make 1 quart. When added to water to make a 2-percent wt./wt. emulsion of chlordane, the resulting emulsion will show approximately two percent cream layer after standing 24 bours.

Chlordane dusts are prepared by first formulating a 50-percent by welght chlordane dust concentrate and then diluting this to the desired concentration. In preparing the dust concentrate, an absorbent type carrier such as diatomaceous earth should be used, and the impregnation process is carried out in a ribbon type blender. A weighed quantity of the absorbent carrier 18 placed in the blender, and an equal weight of the insect toxicant (heated to approximately $150^{\circ} \mathrm{F}$. ) is sprayed by means of air pressure through an orifice directly on the agitated carrier. The spraying arifice should be designed so that a finely atomized mist will be emitted which will cover a comparatively large surface of the carrier, and it should be placed approximately 12-14 inches above the surface of the carrier. If the orifice is at a greater distance fror the carrier, the emitted droplets which cool on emission will become too viscous for efficient blending. In addition, if the effective spraying area is too narrow, the droplets will coalesce, and they will not blend satisfactorily with the carrier. The 50-percent dust concentrate is then run through a hammer or attrition mill for additional blending. A non-absorbent type of diluent or filler such as pyrophyliite is used to cut back the dust concentrate to the desired strength. The dusts finding the most universal application are those containing 5 percent and 10 percent by weight of chlordane. Chemicals having an alkaline reaction should not be used with chlordane because such materlals can cause dehydrohalogenation of the insect toxicant.

Wettable powder - The manufacturing process for this product is the same as that used in preparing the 50-percent by weight dust concentrate.

Aerosols - In experimental studies a liquefied gas aerosol formula $(G-55 \overline{6)}$ containing 4 percent chlordane, 5 percent DDT, 5 percent piperonyl 
butoxide, 20 percent Freon-12, 65 percent methjlene chlor1de, and enough carbon dioxide to derelop 150 pounds per square inch pressure proved one of the bost when sprayed on al unirum and masonite panels and tested for residual torlc1ty against confused flour beetles, Ater1car roach adults and nymphs, and grasshoppers.--Fulton et af. (160).

No aerosol formulas contalning chlordane have been approved by the U. S. Department of Agriculture.

Proprietary insecticides that contain chlordine - Tho Arizona Agr cultural Exper1ment Stat1on (23) in 194811 sted 1004 products reglstered by 101 registrants in that state. Analyses are given of 6 chlordane formulat 10ns.

Frear et al. (156) in 1949 published a list of active ireredients in trade-marked pest control mater1als which 1ncludes about 40 products that contain chlordano.

\section{EWTECT ON PIAIITS}

When added to the soil - When chlordane was added to Chester clas loam, Sassafras sandy loam, Bvesboro fine sand and muck in the reenhouse, 1t depressed plant growth at relatively low levels without causing any obrlous symptoms. Soll type and character, especially the quantity of organic material or colloidal clay present, are important factors in determining the toxicity of organic insecticides. Chlordane infures root systems more than DDT does and is more toxic to seedling plants than benzene hexachloride. Chlordane at the rate of 25 pounds per acre severely affected the germination of seeds.-Cullinan $(23,24)$.

When chlordane was added to the so1l, it appeared to be toxic to all vegetable crops tested.--Foster (151).

Chlordane was mized with Sassafras sandy loam by atonizine an acetone solution onto the 8011 particles while mixing at rates up to 400 pounds per acre (based upon 6 2/3-1nch profile or 2,000,000 pounds of 8011). The treated soll was distributed in 8-inch pots and each pot was planted to three l-year-old Blakemore strawberry plants. Chlordane did not have any deleterlous effect on the growth of the plants.-Goldsworthy (181).

Snap beans from plots treated with 297 pounds of chlordane 50-percent wettable powder per acre had a disarreeable odor when steamed in cotton-plufged flasks. About four months after treatment of the so11, cowpeas were planted after the beans and olra were remored. The vifor of the plants was much botter than in untreated soll and these differences were not the result of root-knot wh1ch wes qu1te screre cr pract1cally all the plot8.--Ell1s and Clayton (133).

At Corvall18, Oregon, in 1947, a 5-percent chlorcane-talc dust at the rate of 27.5 pounds of toxicant per acre applied to the soll with a for- 
t1l1zer spreader produced slight stunting and chlorosis of 11 ma beans.(333).

Chlordane was less toxic than benzene bexachloride (10-12 percent of the ganma isomer) to nitriffing bacteria and funfi when adced to greenhouse soll at 100 and 500 pounds per acre.-Sultin and kenzel (426).

In tests at Bradenton, Fla., 50 pounds of chioriane per acre did not affect the germination of cabbage, lettuce, tomato, eggplant, and pepper. Chlordane 50-percent wettable powder nixed with 4-8-8 fertilizer at the rate of 2 to 1000 proved sefe to use for a perlod of at least 30 days. Tomatoes grown in soll treated with fert1lizer plus chlordane germinated normally. However, application of chlorcane on tobacco seedbeds completely destroyed the germination.--zelsieimer (252).

In tests at Belle Glade, Fla., chlorcane either as a 5-percent dust or as a 40-percent emulsion was mixed with an 0-12-16 celery fertilizer and raked into the soll in amounts equiralent to from 2.4 to 15 pounds of toxicant per acre. Cabbage, penper, tomato, and bean plantec as seeds grow well in all plots; and none of the soil treatments gave any andesirable taste which could be deteoted is the raw caobage.-- Eagslip (21).

In Florida four pounds of chlorkane per acre (in the form of a 50 percent wettable powder) increased the gerzination of sugarcane cuttings. Observations were rade 19, 33, ard 63 days after planting.-Bourne (2).

In Washington a reduction in stano of cucumber seedings 14 days after planting kas highly significant for treatment of soll with chlordane at the rate of 34.8 pounds per acre. This amount of chlorcane also caused a lower stand of bush beans and turnios. No significant differences were found for any rezetables (bush bean, pole beans, beets, carrots, cauliflower, cucumbers, onicns, scuasi, and swiss chard) tested in treatments of 5 pounds chlordane per acre. Chlordane seemec to recuce the quality of the fresh poas, pole beans, and bush beans, but was questionable for carrots and cucumbers.--St1tt ano transon (441).

In Connecticut tests with potatoes grown in soil treated with chlordane at rates of $1,2,4$, and 8 pounds per acre were inconclusire, but any resulting flavor from chloriane was mich I ss objectiorable tian the flavor of benzene hexachloride. - Feenwood and I1ce (196).

Wren applied directlz to plants - In New Jersey established turf of various grasses and clover was sprayed with chlordane at the rate of 25 pounds per acre (50 pounds of 50 percent wettable powder per 1000 gallons of water), 2.5 tines the rate used for control of Japanese beetle larvae. At intervals after treatnent the grass was cut and weigined. Tae chlordane had no effect on the color, general apoearance, or Erowth of the following grasses: redtop, Colonial bentgrass, Astorla bentgrass, Berma grass, orchard grass, meadow fescue, Chewings fescue, perennial ryegrass, Canada bluegrass, Kentucio iluegrass, and rough stalk bluegrass. 
In addition to these grasses, winte clover grew normally. In field tests at five localities there was no indication that the application of chlordane at the rate of 10 pounds per acre had any adverse effect on tine various grasses and clover. - Fleming (139).

In tests in Florlda in 1947 and 1948, 5-porcent chlordane dust and 50-percent chlordane wettable powder at 2 pounds per 100 gallons of water reduced the ylolds of cucuro1ts; in one case the dust reduced the yleld of cucumbers below that of the check plot.-zelshelmer (255).

\section{Chlordane should not be used on cucurb1ts.-Schread (405).}

In experiments at Gonera, Now Yori, a dust containing 5-percent of chlordane produced character1stic symptoms of follage injury on Bluo Hubbard, Table Queen, and Butternut squash, ropresenting the plant spocies Cucurbita mar1ma. C. popo, and $C_{\text {s }}$ moschata. The injury was later outgrown and did not appear to affect the yleld.--Carruth and Howe (66).

In Flor 1da chlordane gave good control of insect pests of cucumber and squash without reducing ylelds in several tests, but in the fall of 1947, a wet season, it severely reduced the yield.-Zelsheimer (254).

In tests on curcubits in Oregon 5-percent chlordane dust, under molst conditions, caused slight burn on 2 varletles and chlorosis on 11 varieties.-Crowell and Morrison (20).

Peaches sprayed with nothing except chlordane developed follege injury in June similar to what has been called Bacterlum pruni.Mar shall (215).

Chlordano spray gave little if any protection agalnst peach scab in Hest Vtrginia, but did not infure the fruit or follage.--Gould and Tajlor (182).

Chlordane 50-percent wettable powder at 2 pounds per 100 gallons of water was sprayed on peaches in North Carolina in 1948. Frult from the chlordane plot was by far the best in two tests, but in another test it was eren signiflcantly worse than frult which had recelved four applicat1ons of benzene hexachloride.-Smith et al. (420).

Chlordane emulsion, 0.5 pound toxicant per 100 gallons, caused moderate injury to Kalanchoo glooullfera cocclnea (referable botanically to Kalanchoe blossfeldiana).-Lumsden and Smith (303).

In North Dakota in 1948, a 5-percent chlordane dust at 35 pounds per acre gave the same yleld ( 144 bushels per acre) of potatoes as did a 5-percent DDT dust. Tho untreated plot ylelded 126 bushels per acre.Munro et al. (340).

In North Dakota in 1947, a 5-percent chlordane dust gare a potato yleld of 260 bughols per acre compared to 239.9 bushels per acre for the 
untreated plot. There were 5 applications of dust at the rate of 20 pounds per acre application. - Post et al. (320).

In tests on Red Warba potatoes in Winnipeg a spray of chlordane wettable powder ylelded 317.2 bushels of potatoes per acre as compared to 83.7 in the check. A chlordane emalsion spray was somewhat less effective. None of the insecticides tested (toxaphene, chlordane, and DDT) impaired the flavor of potatoes tested as boiled potatoes and none of them injured the potato follage.-Mitchener (330).

In New Jersey fleld tests potato plots sprayed with 50-percent chlordane at the rate of 2 pounds to 100 gallons of water, gave a lower yield than plots sprayed with the same dosage of 15-percent parathion or 25-percent benzene hexachloride.--Campbell (64).

Additional observations of the effect of chlordane on plants have been recorded as follows: No effect on the flavor of apples (Weinman 486); no phytotoxicity to the applo tree (Frozal 157); no injury to asters (Jefferson and Pence 232, 240); 1mparted a flavor to dried beans (BIstich and Schwardt 394): chlordane dust caused slight injury to the new growth of cantaloupes and cucumbers (Brooks and Anderson 48); chlordane emulsion applied to corn ears imparted an odor noticeable at harvest (Blanchard and Chamberlin 25); four dustings with 5-percent chlardano Injured the corn (Tissot and Kultert 456); potatoes grown in chlordane treated soll showed no off-elavor (Kuash 278): chlordane wettable powder spray severely burned the follage of the Concord grape (Cox 84); and the follage of prunes and also retarded growth of the tree and development of fruit ( $\operatorname{Cox}$ 85); did not infure red clover (Marshall et al. 314); chlordane emulsion caused some injury to sweet potato follage in the greenhouse (Harrison 206); at prescribed dosage levels chlordane did not injure grass but at extremely high levels (up to 150 pounds per acre) clover and bent grasses were retarded temporarily (Schread 409).

\section{EFFECT ON ANIMAIS}

\section{Ear thworm}

Chlordane 50-percent wettable powder at $1 / 4$ pound per 100 gallons of water reduced the earthworm population of the fairway of a Florida golf course, but the control was not considered satisfactory.-Hayslip (2ll).

\section{Sna11}

A 5-percent chlordane dust proved unsuccessful against Otala lactea, the milk snail, in the San Francisco Bay area in 1947.--Armitage (25).

\section{Black widow spider}

For black widow or other spider control, a light dusting of the area near where the wobs are found is sufficient. The chlordane-1mpregnated 
dust sottles on the web and the spider'a flrst contect proves fatel.-G11bert (124).

\section{F1sh}

Chlordane 18 less toxic to f1ghes than $18 \mathrm{DDI}$ but more toxic than benzene hexachlor1du. Applicat1ons of 1 pound to an acre to outcocr ponds k1lled 87 percent of the blue g1ll suni1sh. W1th applicat1ons of 0.5 pound to an acre most of tho bluegllls as well as other specles survived, and with those of 0.25 pound to an acre pract1cally all fiaces survired. A 12-percent chlordano solution (wt./vol.) in fuel o1l was used in all applications.--Iinduska and Surber (292).

Chlardane of 0.125 p.p.r. k1lled 100 percent and 0.05 p.p.n. k1lled 50 percent of goldfish in 4 days. The correspondine sisureo for DDT vere 0.25 and 0.125 p.p.m.-Ginoburg $(125)$.

Chlordane 18 less toxic to flohes than toxaphene. At Leetown, West Virgin 1a, recent tosts at $0.04 \mathrm{p} . \mathrm{p} . \mathrm{m}$. In st1ll water failed to k1ll several spec1es of warm water fishes, including bluagills, goldfish, and several minnows. Toxaphene kllled all the flah tested at that strength. Chlordane at 1 pound par acre (1n th1s case 0.16 p.p.t.) k1lled 87 percent of the blueg1lls tested. In streams and troughs in Alaske, cblordane proved to be more toxic to trout than DDT and similar to toxapiene in emalsion form in 15-minute treatments. As a suspension it was not toxic to trout in any strength tested below 15 p.p.x., and in fuel o 11 solutions up to 6 p.p.m. no damage was noted. It is concluded that chlordane appears to be damaglng to som fish at 1 pound per acre.Cope (이).

At a routine dosage of 0.1 pound per acre, chlordane is toxic to fish and w1ll significantly reduce the population of ponds. At dosages of 0.05 pound per acre, DDT appears to be somowhat more toxic than chlordane. Chlordane appears to have no slgniflcant effect on the flsh population at a dosage of 0.025 pound per acre. These tests were made on 32 species of f1sh in ponds.-Trazwell (452).

\section{Bird 8}

Chlordane appeared to be $1 / 4$ to $1 / 2$ as toxic as toxaphone to game birds.-Post $(369)$.

\section{Mammal 8}

(a) Rats and Mice - In tests made at the Un1versity of IIIIno1s, chlardane and DDT appeared to be of the same order of toxicity to vblte rats, when admistered as acute and repeated intragastric doseges and when inuncted percutaneously as an oll solution, emulsion ccncentrate and dilutions of the emulalon concentrate. Rats recelving either chlordane or DDT present a wide range of individual suscept1bility, which makes it difficult to establish an absolute minixum or median lethal dose. Anorex1a, logs of welght, hyperexc1tability, and troror a were symptoms produced by both comounds. Tonic and clonic contractions were sifertly 
more severe for those treated with chlordane. Tho time lapse between administration of an acute lethal dose and death is longer for chlordane than for DDT treated rats. There is some indication that chlordane may be slightly more toric to female rats than to males. This was not observed to be true for DDT-treated rats. Chlordane appears to produce in rats less liver damage, but sreater pulmonary damage than DDT.-Ingle (235).

Pharmacologists of the Food and Drug Administration found that the acute oral toxicity of chlordane to rats was $\mathrm{LD}-50500 \mathrm{mg} / \mathrm{kg} \cdot$, indicating that it is $1 / 2$ as toxic as DDT. Chlordane is quite toxic when fed to rats at a concentration of $250 \mathrm{p} . \mathrm{p} . \mathrm{m}$. for 12 weeks. Rats have been seriously injured at this level and fail to survive on higher concentrations. Chlordane is a liver poison and also causes inanition in chronically poisoned animals.--Iehman (287, 290).

Chlordane is absorbed by the animal but its fate and whether or not the chenical is excreted in the urine is unknown. -Woodward et al. (509).

No harm resulted to rats, mice, or guinea pigs when they were subjected for 45 minutes on each of 38 days to air bearing aerosols containing chlordane with methylene dichloride or dimethyl phthalate as solvents, the average initial concentration of chlordane being approximately $1.9 \mathrm{mg}$. per liter. When aerosols with either kerosene, methylene dichloride, or dimethyl phthalate as a solvent were introduced into the chamber at intervals of 10 minutes over an hour in an initial concentration of $10 \mathrm{mg}$. of chlordane per liter, and this procedure kas repeated tiree times on each of four successive days, many of the animals exhibited typical signs of poisoning by chlordane.--Heyroth and Witherup (2l]).

Stohlman et al. (442, 443) reported that the ID-50 of chlordane when fed to rats is $250 \mathrm{mg} / \mathrm{kg}$. compared with $150 \mathrm{mg} \cdot / \mathrm{kg}$. for DDT. Rabbits receiving chlordane excrete organically bound chlorine in the urine. The ID-50 of chlordane when administered intraveneously to rabbits is about $20 \mathrm{mg} \cdot / \mathrm{kg}$. and this is increased to about $60 \mathrm{mg} \cdot / \mathrm{kg}$. through the antidotal action of the barbiturates.

Frings and O'Tousa (158) reported that chlordane is very similar to DDT in its toxic action in mice. The first system affected in the nervous system, and nervous symptoms predominate in acute toxicity. In chronic intorication, however, the liver seems to be most affected. The vapor of chlordane was toxic and wettable powder preparations proved surprisingly toxic.

(b) Dogs - Dogs starved for 24 hours were fed a 50-percent chlordane wettable powder in capsules with oll. It was concluded that chlordane, like benzene hexachloride, is a relatively safe insecticide to use upon dogs. Dogs vary in their susceptibility to chlordane. A dose of $200 \mathrm{mg} \cdot /$ $\mathrm{kg}$. produced convulsions in one dog, while a $700 \mathrm{mg} \cdot / \mathrm{kg}$. dose had little effect on another dog.--Batte and Turk (29). 
(c) Shoop. Cattlo, Goats, Horses, and P1Es - Chlordano appeared from two to four times more toxic than DDT to sheep in acute toxic1ty. Sheep grazed on pastures sprayed with technical chlordane at rates up to 4 pounds per acre showed no apparent 111 effects.- H1nman and Cowan (218).

At Bozeman, Montana, the maximum safe, sinele dose of chlordane for sheop appeared to be considerably less than $0.5 \mathrm{~g}$. per $\mathrm{kg} \cdot$, and for cattle no toxic effect was produced by $0.05 \mathrm{~g}$. per kg. The effects of daily dosages of chlordane administered in capsules for 60 days were: a capsule of 4.5 rams of a mixture of chlordane and zylene (3.5 grans chloraine) was extremely toxic and half this dosage provod about as toxic. A dose of 1 gram of chlordane-xylene mixture ( 0.77 grams chlordano) was continued to the end of the experiment producing only mild symptoms. Sheep dosed with capsules containing 2 grams of xylene alone gare no reaction, indicating that the chlordane was the torlc agent. Six sheep frazed for 21 days imediately following spraying of 1 pound and 4 pounds chlardane per acre showed no indication of toxic effect. -Welch ( 491$)$.

Wettable powders containing less then 1 percent of chlordano had no 111 effects on cattle, sheep, goats, hogs, and horses.-Laake (280).

In toxicological experiments with chlordane at Kerrville, Texas, dipplng goats or sheep with chlordane wettable powder or emulsion did not cause symptoms of poisoning until after six to el git dippings in 1.5-percent chlordane at 4-day intervals. Marked symptoms of poisoning developed in all animals after the last dipping and fatal results ensued. Cattle likewise falled to show toxic symotoms until after four sprayings at intervals of 2 weeks with 2 percent chlordane wettable powder suspension when severe symptoms occurred followed by death. The dip and spray liquids were six and elght times the recomended strength, respectively, and the frequency of application was much greater than in actur field practices. Acute poisoning is characterized by sudden onset, with bleating, groaning, grinding the teeth, blindness, violent strusgling, and blulsh discoloring of the skin before death. In subacute end chronic poisoning the onset is gradual with partial to complete blindness and loconotor ataxia, circling, staggering, avolding imaginery objects, and periodic convulsions. Post mortem findings consist of petechiae and larger hemorrhages under the serose of the large and small intestines and the epicardium, fatty changes of the liver, and congestion of the brain.Badeleff (281), Bushland et al. (58), U. S. Bur. Animal Ind. (464), U. S. Bur. Ent. and Plant Quar. (468).

(d) Man - Undiluted "Velsicol 1068" caused mild irritation of human skin, under the conditions represented by conventional 48-hour patch tests upon 58 subjects. When diluted in mineral 011 and exroyed in 48hour patch testg in a 1 percent (by volumo) solution, "Velsicol 1068" caused no irritant effect.-Goldman (180).

Chlordane applied to the skin causes moderate irritation; the quantity considered danferous upon skin application in solution is for single exposure $1880 \mathrm{mg} / \mathrm{kg}$. and for multiple exposure $40 \mathrm{mg} / \mathrm{kg}$. The The quantities dangerous to man are: for single exposure 113 grams and 
for multiple exposure 2.4 grams per day. The hazards of aerosol formulam tlons of chlordano can ovly be surused. - Iehman (288).

On the West coast only one case of dermatitid among pest control operator using chlordane hes boan revorted and the patient in the patch test showed sensitivity to both netroleur solventg and undilutod chlordano. It is conclinded that chlordane is frobably no more hazarous tinan many other standard producta used in the industry - macobs (238).

The council on Food.8 and Nutrition of the American Medical Association (12) in a recent statement callea attention to the danger to public health created by the wide use of synthetf.c insecticiaes and urged that controls be placed on the sele of products of unknown or incompletely known toxicits. The effects of inhalation and skin absorption of these genthotica must bo deternined as well. as their chronic toxicity to man.

Toxicological irformation on chlordane has been sumarized as follows: Iocal effects: - Chlordane is moderately irritating to the skin. This property is lost on dilution, as fin insecticide formations, and the warning sign of danger is lost. Whe insecticide is absorbod. through the skin, and it has been estimated that daily exposure to about 2.4 gams in solution may be dangerous to man. Symptoms: - The early signs are those of irritability of the central nervous syatem. This leads eventually into convulsions, which are followed by a period of dopression with or without a finel convulsion seluure. Fatal dose: - From the acute standpoint chlordane appears to be only about ono-inalf as poisonous as DDT, but the side effects are such that in the final analysis the toxicity is about 5 times that of DDT. Therefore, the fatal dose lies somewhere between 6 and 60 grams. Fital period: - The onset of symptoms is within 45 minutes after ingestion. Deaths occur occasionally within 24 hours, are frequent between the 48 th and 96 th hour, and if survival extends to the 6th day, recovery is the rule. Pathology: - Inanition is a predominant observation in chronic poisoning, indicating a considerable disturbance in normal physiology. Of the vital organs, the IIver bears the brunt of the poisoning, and the usual degenerative changes produced by chlorinatod hydrocarbons are a constant finding. Treatment: The usual measures should be adopted for removing the poison from the stomach and intestinal tract. Any additional treatment must be symptomatic as no specific antidotes are known.-Lehman (220).

A comparison of the acute oral coses shows that the compounds arrange themselves in the following order from the most toxic to the least toxic: tetraothyl pyrophosphate, parathion, hexaethyl tetraphosphate, toxaphene, gamma isomer of benzene hexachloride, DDT, chlordane, TDE, methoxychlor. Chronic feeding data indicate that parathion is the most toxic, the sequence being parathion, beta isomer of benzene hexachloride, chlordane, DDT, gamma íomer of benzene hexachloride, alpha isomer of benzene hexachloride, toxaphene, IDE, delta isomer of benzene hexachloride, methoxychlor.-Lehman (289).

Additional reports on the toxicology of chlordane have been pub11shed by Lehman (291-295). Chlordane presents the greatest all-around hazards of the commonly used chlorinated insecticides and therefore has 
no place as a contaninant of foods and its household use should be strictly limited. Long-term feeding studies indicate that at every level of feeding chlardane is significantly more poisonous than comparable levels of DDT. From the over-all aspects chlordane is at least 4 times 88 taric as DDT.

\section{SPRAY RESIDUES OF CRLORDANE}

In Coloredo, Gates (122) in 1948, found chlordane residues on alfalfa after the application of one pound of the toxicant as an eirulsion per acre as follows: cut 8 hours after treatment 17.9 p.p.m., 5 days 13 p.p.m., 10 days 4.5 p.p.n., and 15 days after treatment 3.4 p.p.m. A test on houseflies with an extract of the hay cut the first day indicated a chlordane residue one-half that calculated from the total chlorine content.

When chlordane was applied to apple and peach foliage at the rate of 1 pound (an emulsion concentrate) per 100 gallons of water, the initial deposit was 90.2 p.p.w. on apple follage and 139.5 p.p.m. on peach foliage. After 21 days these values fell to 8.3 p.p.m. and none, respectively. Residue determination on alfalfa, sweet clover, red clover, and soy beans indicated that I1ndane and parathion residues are the least persistent followed by aldrin, chlordane, dieldrin, tozaphene, and DDT in that order. The way nature of chlordane residue makes 1t resistant to remoral by rain. Chlordane residues were determined by the total chlorine method using the factor Cl $\times 1.57$ = chlordano.--Decker et al. (101).

Chlordane in milk - A spray containing 0.5 percent of chlordane as a wettable powder was sprayed on milk cows four times between May 15 and August 29. Milk from these cows sampled from May 22 to October 27 showed a maximu arganic chlorine content of 0.8 p.p.m. and an arerage of 0.2 p.p.m. It was concluded that these amounts are so small that they are not regarded as definitely indicating tho presence of chlordane in the milk.-Carter et al. (6z).

The danger of chlordane in milk to the public health was recognized by tho United States Production and Marketing Administration ( 424 ) which on Mas 12, 1949 sent a notice to manufacturers, registrants, and distributors of insecticides containing chlordane varning against the use of chlordane on calry animal 8 , or on forage or other feeds for dalry aninals or animals being finished for slaughter, or for use as insect1cides in dairy barns.

The American Medical Aseociation (16, 17) has exprossed concern over the contanination of the American diet with new materials of unionown toxicity such as chlordane and has urged that voluntary control by tho producers and distributors of the pesticides be instituted lmediately. 
The Iiterature records the results of tests of insecticides containing chlordane on the following lsinds of insects and other arthropods:

$\begin{array}{lcccc}\text { Class and Order } & \text { Families } & \text { Genera } & \text { Soecles } \\ \text { Orthoptera } & 3 & 14 & 21 \\ \text { Isoptera } & 2 & 2 & 2 \\ \text { Mhisanoptera } & 1 & 5 & 5 \\ \text { Anoplura } & 2 & 3 & 5 \\ \text { Mallophaga } & 3 & 6 & 8 \\ \text { Homoptera } & 8 & 19 & 22 \\ \text { Hemiptera } & 5 & 16 & 19 \\ \text { Coleoptera } & 12 & 42 & 45 \\ \text { Lepidoptera } & 11 & 31 & 37 \\ \text { Hymonoptera } & 4 & 12 & 17 \\ \text { Diptera } & 12 & 20 & 39 \\ \text { Siphonaptera } & 1 & 1 & - \\ \text { Acarina } & 7 & 12 & 16 \\ & & 71 & 183 & 236 \\ \text { Total } & & & \end{array}$

\title{
DIPLOPODA
}

\section{Millipedos}

Chlordane, I pound per acre, had little effect on millipedes in grain fields.--Severin (414).

\author{
SCORPIONIDA
}

\section{Scorpions}

In Arizona a 2-percent solution of chlordane in oil killed scorplons in from 12 hours to 3 days. Chlordane killed more quickly than DDT, but did not last as long. The best all around mixture for scorpion eradicam tion at present seems to be 2 percent chlordane, 10 percent DDT, and 0.2 percent pyrethrins in an oil spray-base.-Stahnke (432).

\section{ORTHOPTIRA}

\section{Acrididae}

Grasshoppers are readily killed by the application of chlordane and it is used on a large scale for their control. There apoears to be little difference among species in their susceptibility to chlordane and because 
of this the results of tests with one speciss are about the same as those with another. Sererin (415) reported chlordane to be effective arainst 35 species of erasshoppers.

Belative toxiclties of chlordane and other insecticldes to erasghonpers - In tico labaratory Koarns ot al. (245) made stomach polson tests with chlordano, DDI, and gazma-BEC on the Edult gresshopper Melanoplus differential is (Thos.). Emsisions of zylene solutions of the active conpounds were fed to the grasshoppors in measured drops. Twenty-four bour

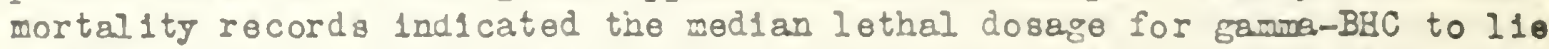
between 5 and 10 mlcrograns, for chlordane jetween 12.5 and 25 microprems, and for DDT to be Feater than 50 mierograms per gram of body welght.

Rhoades and Brett (283) made laboratory tests on three economic species of grasshoppers, Melanoplus bivittatus (Say), M. different18l1s (Thos.), and M. mexicanus mexicanus (SausB.), to determine the1r suscept1bil1ty to certaln synthet1c insectlcide dusts ander difierent constant temperatures. A 10-percent chlordane dust was slower acting than 2-porcent parathion and 5-psrcent gama-BHC dusts, requiring from 43 to 72 hours to reach peak mortalitg. High temperature 1ncreased 1ts effectironess to a lesser extent. Chlordane was less effectire than the other materials except DDT in its action as a contact toxin. There was little difference in the relative susceptibility of the three kinds of grasshoppers to the different insecticldes.

In laboratory tests against Zonocerus elegans (Thunb.) by Petty (363) In South Afrlca a 2-percent parathion dust proved superior to a 5-percent chlordare dust. In general, 10-percent BHC causes a quicker rate of mortality than 5-percent chlordane, al though the final mortality obtained with the two insecticides is similar. A 5-percent BHC concentration appears to be too weak for effective control and 10-percent DDT is relatively ineffective. There is some indication that young hoppers are more susceptible to the poisons than the older ones or adult inoects. The results suggest that a 5-percent chlordane dust should be effective at the rate of 20 pounds per acre.

LaPage st el. (292) in Brazil, using Sch1stocerca cancellats (Sarv.) as the test 1nsect, found that a 5-percent chlordane dust was more toric than dusts contalning 10 percent of dinitro comounds or 20 percent of toxaphene but was loss toxic than dusto contalning 0.25 percent parathlon, or 1 percent of gamma-BHC.

Kearns et 21. (246) made laboratory tests on the grasshopper (y. different1al 18), housefly, Amerlcan and German roaches, milkweed bus, codling moth larvae, black carpet beetle, webbing clothes moti, plum curcul10, chinch bug, and two-spotted mite with several insecticides. The relat1ve toricity of theso matorialo was: dieldrin) aldrin = heptachlor = gamas benzene bexachloride $>$ chlordane $>$ torapheno $>$ DDT. The residual offectiveness of the materials was: dieldrin>DDI>aldrin> heptachlor = chlordane> gama benzene hexachloride. 
Weinman and Decker (489) in Illinois conducted one-quaster acre plot tests against 3 spocios of gresshoppors, Melanoplus differentialis, M. femur mbrus (Des.), and. M. mexicanus. One pound of chlordane was about as effectivo as 2 pounds of toxapheno and wes more rapld in actinn. Toxaphene showed a somewhat longer residual action than chlordano at relatively high dosages. The ID-50 valuss for chlordane against M. differentialis adults when tested for contact effect were 16.3 in 1.947 and 9.8 in 1948; when tested for stomach-poison effect, the values were 21.8 and 12. In these tests parathion and the gama isomer of BHC proved more toxic and toxaokene and DDT less toxic than chlordane. There was some evidence of slight synergism in mixtures of DDT and chlordano. whe greater the ratio of DDT to chlordane, the greater the syner gisu.

Gaines and Dean (160) in Texas determined the relative toxicity of certain insecticines to first to third instar nyinh (M. differentialis) when applied as contact spray and dusts to be as follows:

Treatment
Toxaphene
Chlordane
Parathion
Benzene hexachloride
Iindase

The naterials applied as sprays nade from wettable powders were as effective as when applied as sorey emulsions made from miscible oil concentrates. However, the dosages required to k1ll adults were considerably higher than those required to kill the first and second instax nymphs. In the field tests chlordane and toxaphene were approximately equal in toxicity to young grasshoppers when applied as spray emuls1ons. Dieldrin was more toxic to grasshopper nymphs than benzene hexachloride, chlordane, aldrin, or toxaphene.

Chlordane was first tested against grasshoppers in the field in the sunner of 1946. A dust containing 5 percent of chiordane applied at the rate of 25 pounds per acre killed more than 90 percent of the grasshoppers in a Missour 1 apple orchard and prevented re-infestation for 30 days.-Wingo et al. (501).

Nunerous field tests of chlordane against grasshoppers have been conducted in Argentina (Parker, 356). Canaca (Putnan, 229). South Africa, Australia, Salvador (Zuniga et al., 515), and many of the states. The following report by Parker ( 352$)$, of the U. S. Bureau of Entomology and Plant Quarantine, of field tests made in Arizona, Caldfornia, and Montanit in 1947 presents results typical of those found by other workers.

When applied in sprays or dusts, chlordane and toxaphene caused high mortalities within 24 hours and continued to kill over a period of 1 to 4 weeks. Each of these materials was as effective in oil solutions as in emulsion and when applied from the ground as from airplanes. Chlordane at I pound per acre in such formulations reduced grasshopper populations 
90 to 99 percent in 3 days or less. A susponsion at tinis dosaze gare 90 percent kill, and dusts arerajed 99 percent kill when appiled by alrplane and 64 percent by ground equipment. In field tests ${ }^{\circ}$ th baits 0.5 pound of chlordane, 1 pound of toraphene, 1 pound of parathion, or 0.1 poind of the gamma isomer of BHC per 100 pounds of carrier gave 10 to 15 percent higher kills than 6 pounds of sodium fluosilicata.

Chlardane, applied as an emulsion at the rate of 1 and 1.5 pounds per acre to roadsido and field vegotation in Kanses, caused an arerage reduction of 84 percent in erasshopper population at the end of 72 hours and 100 percent at the end of 7 days. - Dutcher et $\mathrm{al}$. (ól).

In tests made at Fort Collins, Colorado, in 1946, chlardane gave nearly 100 percent control in 8 days or less when applied as a 5-percent dust at 20 pounds per acre, or as a spraj, 2 pounds per 100 sallons, at 50 gallons per acre. For use as a spray 1 pound of chlordane was dissolved in 1 quart of xylene with $50 \mathrm{cc}$. Of Triton $X-100$ and this then axded to 50 gallons of water.-Weihing and Hoerner (485).

Aerosol formulation G-556 containing 4 percent chlordane, 5 percent DDT, 20 percent Freon-12, 5 percent plperonl butoxide, and 6́ percent methylene chloride killed 50 percent of grasshoppers, confused flour beetles, and American cockroaches when they were exposed to thay old residues of it applied at $75 \mathrm{mg} / \mathrm{sq}$. ft. of DDT. The kill was increased to about 80 percent wen the residue was tripled.--irciride et al. (305).

Reports of tests of chlordane against the follcring species of grasshoppers have been published:

Aeolopus turnicull1 bruner1 Caud., the thistle grasshopyer Butcher et al. (60).

Camnula pellucida (Scudd), the clear-winged grasshopper Armitage (25), Hinman and Cowan (218), Parl:er (352), W11scn (407). Chortoicetes terminifera (ilk.) Allman and iright (15).

Hesperotettix speciosus (Scudd.)

Butcher et 르. (家).

Brachistola ma,na (Gir.), the luuber Erasshopper Severin $(415)$.

Melanonlus birittatus (Say), the two-striped Exasshopor Brett anc Rhoaces $(45,47)$, Butcher et al. (60), I1st and Hoerner (201), Munro et al. (332), Phoades end Erett (388), Severin $(\overline{413})$.

M. Lifferentialis (Thos), the aifforential Erasshopper Arritare (25), Erett and Rhordes (45), Eutcher et a?. (60), Gaines (10́j), Gaines and Dean (166), Graham (190), Finnan and Cowan (21E), Kearns et al. (246), I ist and hoerner (301), Parker (352), Fhoades and Brett (388), Serelin (413), Shotwoll (419), Veirman and Decker (488, 409$)$, Veinsan et al. (490), Wilson (1.07).

14. femur-ruirum (Deg.), the red-) cegec Gasshopper

Armitare (25), Butcher et al. (00), Crahar (190), ت̈innan and

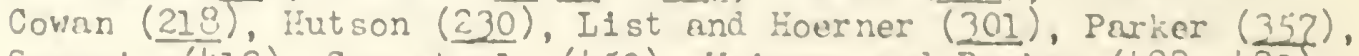
Sever1n (413), Sun et 21. (450), We1man and Tecker (488, 489), Weinman et a]. ( $1+20)$. 
M. marginatua Scudd.

Armitage (25), Parker (357), Hil son (1192).

4. mexicanus devastator Scudd., the devastating Erasshopper

Hinman and Cowan (218).

M. mexicanus mexicanus (Sauss.), the lesser migratory grasshopper Arnitage (25). Brett and Rhoades (45), Butcher et al. (60). Brown (49), Brown and Burtig (21), H1nman and Cowan (218), Munro et al. (332), Parker (352), Rhoades and Brett (388), Soverin (413).

Schistocerca arericana (Drury), the American grasshopper Giffiths and King (127), Grifiths et (198), BIng and Griffiths (262), Thompson and Griffiths (454).

Zonocerus elesans (Thunb.) Petty (363).

Chlordane has been recommended for the control of grasshoppera by the state entomologists of Califarnia (25), Geargia (382), Iliinois (234), Indiana $(275-378)$, Missouri $(328,329)$, Oklahoma (272), South Dakota (416), and Wisconsin $(503,505)$. Young grasshoppers may be controlled by $1 / 2$ pound of chlordane per acre but the full grown ones require 1 pound per acre. Fmulsions have given the best results, water-wettabla powders have been next, and dusts have been least elficfent. The dusts wash off more easily than the other two. If sprays have time to dry, they will not wash readily. The treatments will remain affective fors about 10 days.

The U. S. Bureau of Entomology and Plant Quarantine in Febmary 1950 recomended chlordane for. grasshopper control; 0.5 to 1 pound per acre when applied as a spray and 0.75 to 1.5 pounds per acre when applled as a dust. In the bran-sawdust poison bait mixture 0.5 pound of chlordane may be used in place of 6 pounds of sodium fluosilicate.--Wakel.and and Parker (258, 480, 481).

\section{Blattidae}

Blattella germanica (I), the German cockroach

Purifled chlordane dissolved in a mixture of 4 volumes of reagent grade benzene and I volume odorless kerosene and tested for direct contact toxicity on 4 th and 5 th instar nymphs caused 100 percent mortality at 20 micrograns per square centimeter. The median lethal deposit (ID-50) was 1.7 micrograms per square centimeter.--Brown, Wenner, and Park (53).

When applied directly to adult female roaches chlordane gave 87 per w cent mortality when a 5.0-percent dust was used with a deposit of 3.0 micrograms per square centimeter. In container dusting a deposit of 0.5 micrograms per square centimeter of a 0.5-percent chlordane dust ws th a deposit of 0.75 micrograms per souare centimeter gave a mortality of 90.0 percent. DDT and sodium fluoride were less toxic and gama-BHC was more toxic than chlordane.-Wilswander and Davidson (352). 
When tested in the form of deposits, chlorcane paralyzed roaches more quickly than DDT and toxaphene, but less quickly than gama-BEC.hamman (202).

Residue tests were made by placins the insects on crystalline ceposits of the compounds on I1Iter paper, deposited Irom standard acetone solutions. Chlordane and gama benzene hexachloride were about equal in toxicity and each was more than 1,000 times as toxic as DDT. A chlordane residue of 1.3 micrograms per square centimeter killed 70 percent of the roaches in 120 hours.-lietcalf ( 223 ).

Adult German and American cockroaches were placed for two hours on pieces of cotton twill cloth that had been impregnated with acetone solution of the test material at the rate of $200 \mathrm{mg}$. per square foot. Gama benzene horachlaride was the best of the materials during the first week and was outstanding on 5-hour knockdown, but it had lost most of its toxicity by the 28th day. Chlordane was effective when fresh and was somewhat more lasting than the other materials, although it was not highly effective after 28 days. DDT and toxaphene did not give high kills from 2-hour exposures even when fresbly applied. The American cockroach appeared to be somewhat more resistant than the German cockroach to gamme benzene hexachloride and chlordane, but showed less resistance to DDT. Chlordane and gemma benzene hexachloride sprayed at the rate of $100 \mathrm{mg}$. per souare foot on the walls of kitchens infested with cockroaches (chiefly Blattella germanica with P. americana) eliminated a high proportion of the roaches, and the rooms did not become reinfested with this species during the subsequent observation period of 8 weeks. Solutions of chlordane and a mixture of chlordane and DDT, when dispersed by means of a thermal fog generator, effectlvely controlled carlooaches, but a similar treatment with DDT alone was much less successful. -Gahan et al. (162).

Chlordane should be applied at about $500 \mathrm{mg}$. per square foot. The apparent greater effectiveness of chlordane over DDT may be cue to the persistent sticky nature of the material coupled with a slight funigating property.--Kruse (269).

In laboratory tests chlordano at 2-percent strength in oil solution was more effective than a 10-percent DDT powder.-Gould (183, 184, 189).

Five gallons of a 2-percent chlordanc emulsion applied with a BesEil aerosol generator to a building geve practically 100 percent control, and only a few roaches had reappeared 4 months later.--Somsen and Munro (430).

\section{Periplaneta americana (I.), the American cockroach}

The relative toxicity of chlordane and DDT to the American roach was determined by applying precisely measured dosages to the thoracic tercites. Dosage mortality curves plotted from data obtained in these tests showed chlordane to be approximately three timos as toxic as DDI to this insect. Tho ID-50 for chlordane was found to bo approximately 14 microgrems per 
gram of body weifht as compared to 38 inicrograms per gram of body weight for DDr, when measured 120 hours after treatment. The corresponding values for LD-95 were approximately 25 mlerograms per gram of body weight for chlordane and 70 micrograms for DDT per gram of body weight.--Kearns et $21 .(245)$.

When chlordane was added to a urea-formaldehyde surface coatine (50percent on the dry wolght), It was more effective than DDT but less effective than gamma benzene hexachloride as measured both by tha time to cause 50 percent knockdown and the time to produce 100 percent knockdown.--BI ock (36).

See also unoer Blattella germanica.-Cahar et al. (162).

The value of chlordane in controlling coclroaches has been deroustrated by pest-control operators and others. In general, practical test 3 heve shown better resulis than those in the laooratory.-- 2 nipling (265).

Chlordane has come into wide use arainst cockroaches. Its Iunigating action plays a part in its effectiveness against cockroaches in hidirg places.--Bi shopp (32).

The da.1ry of Oregon State Collegie remained free of cockroaches for 6 months after the application of a kerosene-chlordane spece spray...m Fowler (152).

inen tested in a dust chamber where a very sicall quantity of the test material was applied to a surface, a 5-percent chlordano dust kilied all roaches in 3 days.-Lemon (296).

ChIordane was recomrended as one of the better insecticides for the control of roaches by the U. S. Bureau of Entomology and Plant Querantine (472) in August 1949. Proper application of an insecticide is probably more important than the selection of the one to be used. Elthor powderod or liquid formulations will give satisfactory results.

\section{Gryll1dao}

Gryllotalpa hexadactyla Perty, the American mole cricket

Crlordane was applied to turf as a 5-percent dust at the rate of one pound of actural chlordane to the area and vatered in. There was an. average of nine dead mole crickets on each plot of 100 square feet. The effectiveness of chlordane against mole crickets persists for as long as six weoks to two months after application. Death results from ingestion, contact, and fumigation.-Kelsheiner (250, 25I).

Acheta assimilis F., the field cricket

A 5-percent chlordane dust applied at the rate of 1 pound of toxicant per acre reduced the population about 30 percent within 24 hours. \& 
chlordane-bran bait applied at the same rate reduced the population 50 percent.--lfurro et 2I. (339).

Lemob1us fasc1atus Dog., crickets

Crickets were Dore susceptible to chlordane than to DDT. A 0.05 percent chlordane dust k1lled 88.4 percent of crickets (nywphs and adults) in 2 dajs whlle a 1-percent techn1cal grade DDT dust gave only $84 . ?$ percent mortality.--Sun et el. (450).

Scapter1scus abbreviatus Scudd, the short winged mole-cricket

Wheat bran bait containing 1-percent of chlordane killed 100 percent of these crickets in 10 days. A 50-percent chlordane wettable powder at 4 pounds per 100 gallons of water per 1000 square feet of surface was al so effective.-Hayslip (211, 2l2).

Scapteriscus aclotus R. \& E., tho sourthern nole cricket

S. Vicinus Scudd., the Puerto Rican molo cricket, chango

Chlordane k1lls much faster than does IDT. For seedbeds it is advised to use 50-percent chlordane emulsion at the rate of $1 / 4$ pint to 100 gallons of water, applying this solution by means of a sprinkling can to 1,000 square feet of seedbed area. One application should be sufficient to give protection for at least two to three weeks. Two pounds of 50 . percent chlordane wettable powder mixed with 50 pounds of wheat bran makes an efficlent polson bait. Application is made in the late afternoon or evening. The killing power seems to be increased by ralns or artificiel waterine.-Kelshelmer (250-252).

As little as $1 / 4$ pound of chlordane as a 50-percent wettable powder In 100 gellons of water por 1000 square feet k1lled 95 percent of soutinern mole crickets in 8 day 8 . A 5-percent chlordane dust at 60 pounds per acre k1lled 95 percent in 10 days. The dust was mixed w1th commerclal fertilizer and applied to the upper 2 inches of soll.Ilayslip (21], 2l2).

\section{Unidentified crickets}

The Un1versity of W1sconsin (503) recomends chlordane far cricket control in the same dosage as used for grasshopper control.

\section{ISOPTEPA}

Tarmitide

Trinervitormes hav1land fuller

Whon appliod as 2.5-percent koroseno sprgys to various surfaces tho inftial toxlcities of DDT, BHC, and chlordane are of the same order but 
DDI is wrich noro persistent. SHC and chlordano become ineffective after 1 to 2 muths, but the foxpc effecti of DDT is appreclable after 10 months. None of the thrse was very effectivo upon exameled surfaces. BHC caused a quick knockdown but if insscts were then removed fron treated surfaces, final mortality was often very low, lecovery after knockdown from DDT or chlordans rias rare...-Petty (36́5).

\section{Rhinotormitiden}

Reticul fternes flavioeg (Kollar), the eastern subterranean termita

Chlordane mixed with sandy soil, 1 to 20,000 , remained toxtc for 3 years.--Hetrick (2I6).

\section{Unidentified termites}

So1l treated with a 0.25 -percant emilsion of chlordane remained toxic to termites 13 months after application in a test at Urbana. IlIinols..-Shelford (412).

A second test, made one year after the first test, showed that the soil had lost no toxicity. Furtherrore, thare was no difference oetweon samples from a 3 inch and an 8 inch depth.-.shelford ( 428 ).

\section{THY SANOPMIRA}

\section{Thropid20}

\section{FrankI Inje]1a fusca (H1nds), the tobacco thrips}

In omall plot tosts at Baton Rouge and Bossier City, Loulsiana in 1948, three epplications of 10-percent chlordano dust at tho rate of 10 pounds per ecre at weekly intervals, beginning with the appearance of tho first true leaf, gave satisfactory control. Although this treatment resulted in significant increases during the seedling stage in height and leaf surface of the treated plants as compared to the untreated checks, the differences were not reflected in yleld between treated and untreated plants.--Newsom et al. (348).

Heliothrips haemorrinoialalis (Bouche'), the greenhouse thrips

In laboratory tests with adult female thrios chlordane was legs toxic than DET, gamma-BHC, THPP, and parathion; about as toxic as toxapheme; and more toxic than IDE and methoxychlor. A concentration of 0.0035 percunt gave a fifty percent kill.-metcalf (322), Metcalf et al. (225).

Scirtothrips citri (Moult.), the citrus thrips 
Tean1othrin: stgilez (Mor.), tho Elar1olus thrips

For thrips on gladjolus chlcrdaise dust 18 wore eifective than DDT dust but not as effoctivo as tho sprey. During Marci and April when DDI spray are not effective chlcrdano spregs give nore satiafactory control especially where a serero infertation has dereloped.-Magle (309).

An emalsion of 0.5 pound of chlordane per 100 gallons of water appliod 6 timos at weokly lntervals at the rate of 130 gallons per acre gave 94 percent clean flowers up to two weeks after the last eppl1cat1on.-Sm1th (423); Smith and Boswell (424).

A 5-percent chlordane dust and a 50-percont chlor cane wettable powder at 2 pounds per 100 gellong of water were very effective in killing thrips within the leaf folds and flover buds.-miggie and Belshe1rer (310).

Good control of thrips on Gladiolus was obtained from the use of 5 percent chlordano dust.--Jenising (24l).

Thrips tabec1 Ind., the orion thripg

Wen teated on potted onfon plants in the Eseenhouse, a dust mixture contalning 2 percent chlordane gare excellent control of the onion thrips.Sun et al. (450).

In trials in Indlana in 1946, 2- and 5-percent chlordane dusts and a 5-95 DDI-suifle nixture gave the freatest reduction in the thrips populat1on.-Gould (186).

A pyrophyllite dust contalulag 5 percent of chlordare, applied at the rate of 10.5 pound per acre, caused a 98 percent reduction in the nurber of thrips 24 hours after treatment and a 71 percent reduct $10 n 5$ days after treatment. Those tests vere made on seedling cotton at Bayview, Texas in the spring of 1947 on 0.1 acre plots.-Fife et el. (132).

In $194 ?$ in Hew Jersey, a 3-percent chlordane dust gare an outstanding reduction in thrips population and a fairly good increased yleld of onions.-Pepper (262).

Cblordano emulg1on spray, 1 pound per 100 gallons of water, sare promising results in 1947 in tests at Twin Falls, Idaho, causing a reduct1on of 77 percent in tho population.-Dougless and Shirck (212).

Chl crdane, applied as a dust at weokly intervals, gave rery good control of thrips on onlons, reducing tho number to an arerage of less than 9 per plant, whareas the untreated plants averaged 31 thrips per plant throughout the season. The plants in all treated plots were larger and greener than those in the chock plots.-Floyd and Sw1th (146). 
ANOPLURA AND MAIIOPBAGA

Chlordane has been tested against sereral species of sucking and biting Iice and found to be highly effective.-Bushland (52); Bishopp and Knipling (34).

Testo with identified species have been reported as follows:

$$
\text { Anoplura - Haematopinidao }
$$

Haematopinus adventicius Neum., the hog louse

In one test with a few animals chlordane wettable powder spray at 0.2 percent concentration gave apparent complete control of hog lice.U. S. Bur. Ent. and Plant Quar. (468).

Sprays containing 0.2 percent of DDT, TDE, or chlordane completely elimininated lice on hogs in tests made in Massachusetts in 1946. No irritation or harmful effects from the insecticides were observed. The chlordane acted most rapidly and the lice began to drop in a few minutes.Sweetman (45I).

Heomatopinus eurygternug (Nitz.), the short-nosed cattle louse

Iinognathus Vituli (L.), the long-nosed cattle louse

A 0.5 percent chlordane suspension destroyed all short-nosed and long-nosed lice on hearily infested cattle in less than 8 hours, was nonirritating, and a single application was nontoxic to newborn calves.J. S. Bur. Animal Ind. $(465)$.

Tests on cattle against sucking lice of the species Haematopinus eurysternus and on goats against biting lice, Bovicola spp., indicate that the motile forms are killed with lower concentrations of chlordane than are required for DDT. - Knipling (264).

Ilnognathus setosus (OIf.), the dog sucking louse

No Ilce were found on dogs 24 hours after they had been dipped in a 0.42-percent technical chlordane emulsion.-Turk and Batte $(\underline{460})$.

$$
\text { Anoplura - Pediculidae }
$$

Pediculus humanus corporis Deg., the body louse

Chlordane was found to be outstanding against the body louse, but lesa persistent than DDT or toxaphene.-Bishopp (32).

When impregnated in cloth or when employed in powder form, chlordano proved much more effective than DDT. It also acted faster than DDT, paralyzing lice in 3 hours as compared with 6 hours for DDI. When compared 
with DDT on tho bas1s of persistence, 1-percent and 5-percent powders of tho two materials were about equal - perhaps chlordano was sl1 tly more effective. In washing tests, garments impregnated with DDT were more resistant to loss of effectirezess than were those treated with chlordane.Knipling (264).

When applied to cloth and evaluated by the beaker test nethod, technical chlordane was effective at a concentration of 0.0005 percent. Iice exposed on cloths 1mpregnated with 1 percent of insect1cide vere paralyzed w1thin 3 hours by chlordane. Chlordane was about as longlasting as DDT. Sleeves of cotton underwear cloth 1mpregnated with 2 percent of the insecticides were compared for resistance to laundering. Toxaphene, which was the most effective treatment, remained lethal to 11 ce after four 15-minute bollings in a 1-percent soap solution. DDT lasted almost as long and was superior to chlordane.-.ddy and Bushland (126).

A single dose of chlordane was administerec orally to raboits at a dosage of $300 \mathrm{mg} \cdot / \mathrm{kg}$. When undiluted chlordane in a gelatin capsule was fed to the animal, the mortallty of $11 \mathrm{ce}$ feeding on the rabbit was 16 percent after 4 days. When administered as a 10 percent solution in corn oll ( $5 \mathrm{mg} \cdot / \mathrm{k}_{\text {. }}$ ) through a stomach tube, the mortality of lice was 60 percent after 2 days, but the rabbit died after 4 days. One rabbit recelving $300 \mathrm{mg}$. chlordane per kg. in corn oll died within 2 hours; another recelving $25 \mathrm{mg} \cdot / \mathrm{kg}$. died within 3 bours.-Knipling et a․ (266)

\section{Mallophaga - Menopon1dar}

Eomenacanthus stramineus $($ Nitz.), the chicken body louse

Menopon gallinae (I.), the shaft louse

$$
\text { Mallophaga - Philoptoridao }
$$

Gonlocotes hologaster Nitz., the fluff louse

Dusts containing 2 or 5 percent of chlordane,applied at rates from 2 to 10 pounds per 100 square feet of so11, gave excellent results and were somewhat superior to the 3-percent DDT dust. The b1rds remalred free of lice for 4 to 5 weeks.-Crelghton et al. (82).

One application of 5-percent chlordane dust to the birds was less efficlent than sodium fluoride, but gave satisfactory control up to 70 days after treatment. Pens treated with 2-percent and 5-percent chlordano spriniled over the litter at the rate of 2 pounds per 100 square feet were st1ll free from 11 ce 70 days after treatment.--Edgar (130); Ed gar et al. (131).

In laboratory tests in Kentucky excellent control of body, shaft, and fluff 11 ce was obtalned with one application of 5-percent chlordane powder on the blrd.--Ky. Agr. Expt. Sta. (258). 
Cucletogaster heterograghus (Hitz.), the chicken head louse

Itpeurus caponis (L.), the wing louse

Same as for Momenacanthus stramineng.-Bdfar (130); rdgar et al. (131).

$$
\text { Mallophaga - Trichodectidao }
$$

Boricola capree (Gurlt), the red goat louse, the goat biting louse

B. crassipes (Rud.), the yellow louse on goats

Chlordane and DDT are about equal in efficiency against the red and yellow goat lice. In a limited number of tests a 0.2 -percent concentration of chlordane in dip form with either wettable powder or emulsion gave complete control which was malntained for at least 4 months.- U. S. Bur. Int. and Plant Quar. (468).

B. equi (I.), the horse biting louse

Chlordane emalsion was better than chlordane wettable powder, which - was better than DDT wettable powder. The LD-50 of chlordane in emalsion form was 0.043 percent. The spray s were applied to Shetland ponies by means of an electric hand sprayer.--Batte and Gaines (요).

Boricola spp.

See under Haematopinus eurysternus.-Znipling (264).

EOMOPTERA

Aleyrodidac

Aleurocanthus woglumi Ashby, the citrus blackfly

The addition of 0.9 ounce of chlordane per gallon of light-medium emulsion oll which was applied as a 1.67-percent water emulsion did not enhance the toxicity of the oil to 1st, 2nd, and 3rd-1nstar larvae or to pupae.-Plummer and Shaw (268).

Chlordane in Velsicol AR-60 or kerosene exhibited low toxicity... Woglum et al. (506).

Trialeurodes vaporariorum (Westu.), the greenhouse whitefly

When applied as dusts containing 1 percent of the toxicant, chlordane was less toxic ( 52.6 percent mortality) than gamma-BEC (97.8) or aorosol grade DDT (85.6) to adults.-.Sun et al. (450). 


\section{Undent1flod specles}

$\Delta$ 5-percent chlordane dust applied for the control of the serpentine leaf miner on asters controlled whitefly, but was inferior to a EHC dust ( 0.75 percent gama cortent) for this purpose.-Jefferson and Pence (232).

\section{Aphidao}

Anuraohis persicae-rlger (Smith), the black peach aphid

In Orecon a 2-percent chlordane dust killed only 18.5 percent of these aphids on peach trees.--Jnnes and Rosenstiel (244).

Aph1s gossypi1 Glor., the cotton aphid, the relon aphid

In laboratory and cage tests at Waco, Texas in 1946, chloráano gave promising results against cotton aphids.--Harned (205).

At 10- and 20-percent concentrations chlordane dust was effective against cotton aphids, but not quite so effective as correspondins concentrations of toraphene, or BEC (gama 1somer 5.75 percent).--Ivy and Ewing (232).

At Florence, South Caroline in 1947, 10- and 20-percent chlordane dusts gave good control of cotton aphid, but a mixture of 10-percent chlordane and 5-percent DDT permitted a build-up of aphids in one test.--Eondy (4I).

A 5-percent chlordane dust d1d not affect the aphid population.Arant $(\underline{20})$.

At a dilution of 1 to 300 of an emulsion concentrate containing 20 grams of insecticice per $100 \mathrm{ml}$., chlordane was elightly less toxic than technical Grade DDI to the melon aphid of various ages.--Sun et al. (450). In additional tests these vorkers ( 449 ) used the melon aphid as a test insect to evaluate different chlordane formulations.

Chlordane 25-percent emulsion at 1:400 was unsatisfactors in controlling aphids (chiofly this species) on celery in Florida in 1948. No injury to celery plants was observed.-- Hyl1e (514).

Aphis fabae Scop., the bean aphid

Mixtures of nicotine and chlordane dusts tend to produce mortalities slightly cxceeding those to be expected from similar joint action, but the differences may not be great enolifh to prove synergist1c action. At the 50-percent mortality level nicotine is 1.49 times as toxic as chlordane; at the 90-nercent level nicotine is 1.43 times as toxic as chlordane.--Sun (445). 
In the form of a l-percent dust chlordane was more effective than aerosol grade DDT against the bean aphid in greehouse experiments in which aphids of various ages were included in the mortality counts.-Sun et 리. $(450)$.

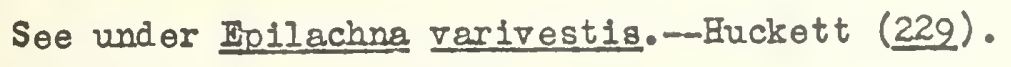

Aphis spiraecola Patch, the spirea aphid

See under Macrosiphum pisi.-Kearns et al. (245).

Macrosiphum pisi (Klb.), the pea aphid

In laboratory tests 10-percent chlordane was more toxic than 1-percent nicotine, and 2-percent chlordane was less toxic than 1-percent gamma-BHC.--Bishopp (32).

In parallet tests with chlordane and DDT, applied as aqueous dispersions to the spirea aphid and to the pea aphid, chlordane proved several times more toxic to these insects than DDT. The pea aphid is the less susceptible of the two species to both compounds.--Kearns et 2l. (245).

In laboratory tests 2-percent chlordane dust gave higher mortalities than aerosol grade DDT and toxaphene of the same concentration on adults of the pee aphid. In greenhouse and field experiments where aphids of various ages were included in the mortality counts, however, the results show that chlordane was less effective than technical grade DDT against the pea aphid. - Sun et al. (450).

A 5-percent chlordane high pressure aerosol gave 72 percent control of pea aphid in Virginia; DDT gave 94 percent control.--Anderson and Hofmaster (12).

Macrosiphum solanifoli1 (Ashm.), the potato aphid

Tests made in Wisconoin in 1946 with tribasic copper sulfate plus insecticide showed chlordane both as a dust and as a spray to rank below HETP, DDT, nicotine, and BHC.--Wis. Univ. (504).

Same as for ㅆ. pisi.-Sun et al. (450).

Myzus persicae (Sulz.), the green peach aphid

For the control of the green peach aphid on shade grown tobacco in F'lorida in 1947, chlordane at first gave an excellent kill, but later applications (perhaps of a different compounding) did not prove effective.-Wilson et al. (492).

In greenhouse experiments a l-percent chlordane dust was more effective than a 1-percent technical grade DDT dust.--Sun et al. (450). 
In Florida chlordane 40-percent emulsion at 1:400 skowed promise, but was less offective than $B \mathrm{HC}$, parathion, and DDT omulsion in combat1 ing these aphids on cabbages.--Eayslip (211).

Phyllaph1s fagl (I.), tho woolly beech aph1d

A 50-percent chlordane wettable powder at 1 and 2 pounds per 100 gallons of water proved ineffective.--terr (260).

Phopalosiphums pseudobrassices (Davis), the turnip aphid

A 5-percent chlorcane-pyrophyllite dust in laboratory tests k1llod only 1.5 percent of these aphids on kale leaves after 24 hours.--3rooks and Anderson (48).

Same as for M. persicae.--Haysip (211).

Bhopalosiphum rufomaculatum (W1lson), the Ereen chrysanthemum aphid

In tests to determine the fumigant action of chlordane on apterous females, alr currents hed a marked effect on the toxicity. A 60-percent solution was tested at dilutions of 0.125 and 0.5 pound actual chlardane per 100 gallons. In still air 0.5 pound per 100 gallons causec a zortality of 87.9 percent to aphlds exposed to the vapor; in an air current of 3.7 miles per hour the mortal1ty was 35 percent.--Dustan et al. (121).

S1pha flava (Forbes), the yellow sugarcane aph1d

In Louistana in 1947 and $1948 \mathrm{chlordane}$ gave nearly perfect control.--Dugas et al. (117, 112).

\section{Cer $\operatorname{cop} 1 \mathrm{a} \theta$}

Philaonus loucophthalmus (I.), the neadow spittlebug

Five- and 2-percent chlordane dusts at the rate of 20 pounds per acre gave almost complete control of spittlebug nymph on strawberries and sweet clover in W1sconsin in 1947 and were zore effectire than a 5percent DDI dust. On alfalfa a 5-percent chlordane dust was the most effective of all materlals tested, includine hexaethyl tetraphosphate, tetraethyl pyrophosphate, DDT, and BHC.--Chamberlin et al. (69).

In M1chigan in 1947 mamoth clover dusted with 2-percent cinordane plus 3-percent DDT at the rate of 30 pounds per acre had 28 percent of the stems infestod 7 days after treatment as compared to 42 porcent infestation for 5-percent DDT and no 1nfestation in plants treated with 0.36 -vercent gemma-BHC dust.--Pederson and Sherman (361).

Chlordane emulsion and wettable poider at 1 pound of toxdcant per acre in 1948 killed about $2 / 3$ of the nymphs, proving less effective than it did in the 1947 tests.--Chmberlin and dedier (68). 
A 3-percent chlordane dust gave 93 percent control of meadow spittlebug on strawberries.-Wis. Univ. (503).

Chlordane controlled spittlebugs but was inferior to methoxychlor.-Wilson (500).

\section{Cicadellidae}

Circulffer tenellus (Baker), the beet leafhopper

In Utah chlordane dust, spray, and emulsion, applied four times at weekly intervals, beginning with date of planting and during the period of leafhopper morement, did not control the curly top disease of tomatoes because the leafhoppers fed upon the tomatoes, thus transmitting the disease before recelving a lethal dose.--Dorst and Peay (111).

Fupoasca fabae (Harr.), the potato leafhopper

In Indiana in 1946 chlordane proved inferior to DDT.--Gould (188).

When compared as dusts 3-percent chlordane was inferior (50.6 percent mortality in 3 days) to 0.5 -jercent DDT (94.7 percent mortality).-Sun et al. (450).

Chlordane, when applied alone, seemed to have an attracting effect on the leafhoppers. One week after treatment the potato leafhopper population increased on chlordane treated plots 2.4 times the untreated and by the end of 4 weeks, increased 3.1 times. The plants in the chlordane plots yellowed and were stunted in sharp contrast to the untreated plots which were also seriously injured by the leafhoppers, but didn't sustain such high numbers. Chlordane, 1 pound per acre decreased alfalfa seed yield 25 percent, but the combination of 1 pound DDT plus $1 / 2$ pound chlordane (the best treatment tried) increased the jield 102 percent..Wilson (500).

\section{Unidentified species}

Some leafhoppers were killed by chlordane ( $3 / 4$ or 1 pound per acre) applied for the control of Erasshoppers.-Severin (4I4).

\section{Cicadidae}

Magicicada septendecim (I.), the periodical cicada

Chlordane spray, 6.4 gall ons of 50-percent emulsion or 8 pounds of 50-percent wettable powder per 100 gallons of water, was ineffective even when the cicadas were caught in the spray fog and well covered.-Cutright (26). 
In field tests in Virginla in 1948 the application of chlariane spray ( 3.75 pounds per 100 gallons of water) to apple trees and to the undergrowth and soll beneath the trees did not retard the emereence of cicadar. In laboratory tests cicadas in cages were sprayed directly with this same chlordane spray. After 24 hours 39 percent of the cicadar were still normal.--ioodside (510).

\section{Coccidae}

Coccus pseudomagnoliarum (Kuw.), the citricola scale

Chlordane was not promising in tests in southern California.-Ewart (134).

Parlatoria oleae (Colvee), the olive scale

A spray of 1 quart chlordane in 100 gallons of water plus 3 pounds of 15-percent parathion applied in November reduced the percentage of scalo-infested olives from 96 to 67 in 11 months.-Stafford (436).

Pgoudoccoccus marit1mus (Errh.), the grape malgios

Chlordane spray (2 pounds of 50-percent wettable pouder per 100 gallons of water) caused 49.8 and 43.6 percent mortality one weeks after applications on May 19 and June 2.--Heiswander (343).

\section{Delphacidae}

Peregrinus maidis (Asbm.), the corn lantern fly

A 5-percent chlordane-pyrophyllite dust, applied 3 times to a total of 28 1/4 pounds per acre, gave a control of 62 percont of the flies.-Brooks and Anderson (48).

\section{Psyll1dac}

Psylla pys 1cola Foerst., the pear psylla

Chlordane emulsion concentrate (50-percent), 16 ounces to 100 gallons of water, was comparatively ineffective in a single test. $O D$ pear trees in New York the number of nymphs per spur two days after appl1cation of this spray was 14.3 as compared to 28.2 on untreated trees and none on trees treated with tetracthyl prrophosphate, 4 ounces plus 2 ounces of spreader per 100 gallons of water.--lamilton (이).

Chlordane spray ( 1 and 1.5 pounds por 100 gallons of water) had an Initial efflciency of 61.5 and 69.3 percent, whereas the bost matertal tested, Darathion, at $11 / 4$ ounces per 100 gallons had an eficiency of 99.5 percent.-- Carlson and Nowcomer $(\underline{65})$. 


\section{HERMIPTERA}

Coreidae

Anasa tristis (Deg.), the squash bug

In a laboratory test a 5-percent chlordane dust caused 100-percent knockdown and 85.7-percent mortality of the bugs in 48 hours. A 2.5percent chlordane dust was almost as effective, causing 95-percent knockdown and 75-percent mortality in the same time. In a field-cage test 5percent chlordane caused 80.5-percent mortality.-Walton (483).

DDT was relatively ineffective as compared with chlordane when applied to the adult squash bug in the form of aqueous sprays as well as dusts.-Zearns et al. (245).

Leptocoris trivittatus (Say), the boxelder bug

A 2-percent emulsion spray of chlordane killed 97 percent of the insects within 48 hours and showed residual action.--ikunro and Post (339).

Leptoglossus gonagra (F.), the citron plant bug

In Florida this bug was controlled by 30 to 40 pounds of a 5-percent chlordane dust per acre or 0.6 pound of 50-percent wettable chlordane per 100 gallons of water.--Thompson and Griffiths (454).

\section{Livgaeidae}

Blissus leucopterus (Say), the chinch bug

In tests made in Connecticut chlordane gave the best control, followed by DDT-sabadilla mixture and DDT alone. Chlordane, applied to an infested lawn as a 5 percent dust at the rate of 5 pounds to each 1,000 square feet, destroyed both adult and immature bugs in 24 hours and its residual action persisted for two to three months or Ionger.-Schread (406, 408$)$.

See also under "Unidentified ants".--Kelsheimer (252).

Nysius ericae (Schill.), the false chinch bug

In small-scale tests 5 percent chlordane dust gave 100 percent kill in 48 hours. - Smith (425).

Oncopeltus fasciatus (Dall.), the large milkweed bug

Adults in battery jars were exposed to chlordane vapor. At the end of one day the mortality was 66.6 percent and at the end of two days it was 100 percent.-Dustan et al. (121).

See under Blattella germanica.--Drown, Wenner, and Park (53). 
Mridao

Adelophocor1s Ineolatus (Gooze), the alfalfa plant bug A. rapldus (Say), the rap1d plant buf

Chlordane wettable powder and emulsion at 1 pound of toxicant per acre gave very good control of these insects in alfalfa in Wisconsin. In tests of sprajing equipment very good control of forage insects was obtained at 30 to 40 pound pressures and 15 to 30 gallons per acre. The method of application appears to be secondary to dosage per acre of tie toxicant. - Medier and Cinamberlin (20).

Dicyphus minimus Unl, the suckfly

A 5-percent chlordane talc dust was effective against sickfly on tomato in the lover R10 Grande Valley in 1949. Nine days after dustine the number of suckflies in 20 net sweeps was reduced from 501.? on untreated plants to $?$ on plants treated with the chlordane dust.- 4 ene (94).

\section{Lygus el1sus Van Duzee}

In tests made on alfalfa plots in Arizona in 1947 and 1948 one pound of chlordane was almost as effective as 1.25 pounds of DDT. The average Lygus reductions were 91 percent with chlordane and 92 percent with DDT. Dusts, emulsions, and suspensions of chlordane were equally effective.-Russell (401).

\section{Lygus hesperus Knlght}

A 5-percent chlordane dust was less effective than a 0.5 percent parathion dust.--Smith (425).

Same as for Iygus el1sus.--Rus sell (401).

Eygug eblineatus (Say), the tarnished plant bug

Chlordane showed some promise against tarnished plant oug.-Bishopp (32): Gould (186).

In cage tests at Tallulah, Ioulsiena a 20-percent chlordane dust killed 60 percent of these burs in one test and 66 percent in another test. The highest chlordane mortalities were caused by a dust containing 10 percent chlordane plus 2.5 percent parathion (98 percent k1ll) and by a mirture of 10 percent chlordane plus 5 percent DDT ( 34 percent kill).-Scales and Smith (1403).

In laboratory tests a dust containing l percent chlordane killed 35.8 percent of tho adults in 2 days, whereas a dust containine 3 percent acronol rade DDT killed only 54 percent. - Sun et al. (450).

Cilordane did not give as good resurts as DDT and BHC, although a combination of this material with DDT showed promise.--Pederson (360). 
In fields lightly infested with tarnished plant bugs chlordane, I pound per 100 gallons per acre, increased the yield of ladino clover seed 14 percent and DDT spray, I pound per acre, increased the yield 22 percent.-Hedler and Chamberlin (220, 321).

In tests in Indiana in 1948 chlordane completely controlled the insects (tarnished plant bug and stink bug) causing catfacing of peaches. Sod areas around the orchard were sprayed and it was found to kill remarkably well for a period of two weeks or longer.--Marshall (315, 316 ).

Same as for Lygus elisus.-Russell (401)

\section{Iysus spp.}

Chlordane showed some promise against Lygus bugs on alfalfa and sugar beets.--Bishopp (32).

Amblytylus nastus (Kirgchbaum)

Miris dolabratus (I.), the meadow plant bug

A 5-percent chlordane killed 96 percent of the former and 88 percent of the latter on Kentucity bluegrass.-Ky. Agr. Expt. Sta. (258).

Psallus seriatus (Reut.), the cotton fleahopper

In laboratory and cage tests at Haco, Texas during 1946 5-percent chlordane was very toxic to cotton fleahopper adults and nymphs, but a 1 -percent dust was much less effective than the same concentration of DDT or toxaphene. Neither of these concentrations was as effective as a dust formulation of benzene hexachloride containing 0.575 percent of the garma isomer.-Ivy and Ewing (237).

In Texas during 1947 a 5-percent chlordane dust, applied once at the rate of 12 pounds per acre, was effective ( 83.4 percent control)... Gaines and Dean (164).

\section{Pentatomidae}

\section{Euschistus servus (Say)}

Same as for Nezara Viridula.-Rihord (391).

Fuschistus spp.

In tests to control the catfacing of peaches in Virginia in 1948 chlardane spray, containing 2.5 pounds of 40-percent wettable powder per 100 gallons of water, gave some control, but was inferior to DDT and sabadilla.-Woodside (512).

Murgantia histrionica (Hahn), the harlequin bug 
of a 10-percent chlordane dust was 5.1 pounds per acre. Chlordane and tozaohene were more toxic than DDT or sabadilla as 10-percent dusts. In cage tests a 10-percent chlordane dust caused 34.5 percent mortal1 ty 5 cays after application.--Gaines and Dear. (165).

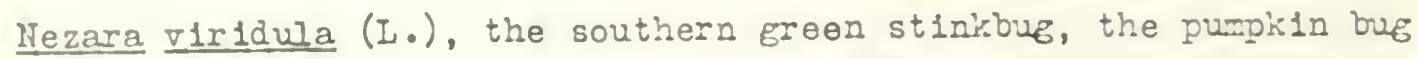

In laboratory and cage tests at Vaco, Texas chlordane gave proulsing results. A 20-percent chlordane dust was less effective than toxaphene againet adults and nymphs. - Ivy and Ewing (237).

Five percent chlordane dust was effect1ve.-Zelsheiner (248, 252).

A dust contalning 10 percent toxaphene - 5 percent chlordane - 35 percent pyrophyllite was highly effective in controlling these stinkbugs on spring planted cowpeas on the Teras Gulf coast.- Riherd (29l).

Unidentified pentatomidae

Chlordano gave no control of catfacing in Illinols peach orchards is 1947 when applied five or more times beglnning with the shuck split 3 tage. It was used at the rate of 1 pint of 61 percent concentrated emalsion per 100 gallons of water.-Chandler (22).

\section{Tingldae}

Corythucha crdoniae (F1tch), the hawthorn lace bue

Chlordane spray made by diluting a mixture of 1 part of chloriane, 1 part Triton X-100, and 2 parts xilene with water to a content of 0.12 percent chlordane was effective in controlling this lace bug on Pyracantha shrubs. A DDT spray of the same strength was slightly more effective.-Wart on (483).

\section{COLEOPTERA}

Carabidae

\section{Agonoderus comma (F.)}

A 5-percent chlordane dust, applied lightly to the so1l surface, kllied 100 percent of these beetles in the soll after 120 hours. Corn seed treated with chlordane dust at the rate of 2 to 3 ounces per bushel was completely protected against beetle attack.--Johnson (243).

\section{Unidontifled specles}

Samo as for Hypera post1ca.-Sevorin (414). 
Diabrotica undecimpunctata howardi Barber, the southern corn rootworm, the spotted cucumber beetle

In laboratory tests on the spotted cucumber beetle 5-percent chlordane dust caused 100 percent knockdown in $I$ hour and 100 percent mortality in 7.5 hours. In field plot tests on sugar pumpkins infested with both species 5 -percent chlordane dust gave 94.8 percent control.--Walton (483).

In laboratory tests a dust containing 0.5 percent of chlordane killed 100 percent of adult spotted cucumber beetles in 4 days. In greenhouse tests a 3 percent chlordane dust killed 75 percent of the beetles in 2 days and 97.7 percent in 4 days.--Sun et al. (450).

In Indiana in 1946 chlordane gave a fair kill of spotted cucumber beetles.--Gould (186).

In tests made in Wisconsin in 1946 HETP, BHC, and chlordane showed effectiveness ranging between that of 10-percent sabadilla and 1.25 percent DDT.-Wis. Univ. (504).

A spray containing $0 . I$ percent of chlordane made by diluting a concentrated emulsion was about as effective as a 4-percent DDT emulsion spray and somewhat less effective than a 0.1 percent benzene hexachloride emulsion spray in preventing injury to peanut pods at Beltsville, Maryland in 1947.--Dobiins and Fronk (108).

Chlordane at 4 pounds per acre was the best insecticide tried, reducing the percentage of plants danaged from 33 in the check to 2.5.-Kulash (272).

Three applications to peanut foliage of emulsions containing chlordane, at the rate of approximately 0.38 pound of the active ingredient per acre-application, gave significant control at Beltsville, Maryland, where the infestation was less severe than in southeastern Virginia. Seven applications of certain formulations were made to the follage on small plots of peanuts at Holland, Virginia during the period June 19 to August 23 in order to obtain maximum control. The following formulations gave significant control: 5 and 10 percent chlordane dusts, and 0.5 and 1 percent of chlordane in emulsion form.- Tronk and Dobbins (159).

Chlordane, 5 pounds per acre, was mixed with 4-22-4 fertilizer. Twenty-four days after planting 6 percent of the plants in the chlordane plots were destroyed by the rootworm. Plants in the chlordane plot were much larger and greener from the time of emergence until the plants were waist high. The average yield of corn from this treatment was chlordane, 77 bushels per acre; fertilizer alone, 58 bushels per acre; and check, 49 bushels per acre.--Floyd and Smith (147, 149).

Epitrix cucumeris (Harr.), the potato flea beetle

In field tests chlordane emulsion ( $20 \mathrm{~g}$. in $100 \mathrm{ml}$.) diluted 1 to 500 gave a control of 90.2 percent in 3 days.--Sun et al. (450). 
A 50-percent chlordane wettable powder (1/4 pound tor1cant per 100 gallons of water) was less effective than a micronized DDI wettable powder ( $1 / 3$ pound toxicant per 100 Eallons of water) in reducing flea beetlo damage on potatoes. Chlordane produced slenlficantly better jlelds than $D D T$ in a field trial..-Turner and Woodruff (462, 463).

\section{Evitrix hirtipennis (Melsh.), the tobacco flea beetle}

A spray containing 1 pound of cblordane as a 50-percent wettable powier and 3 pounds of Fernate in 100 gallons of water gave 36 percent uninjured plants in tobacco plant bods as compared to 17 percent in the check and 99 percent in the bed treated w1th DDI spray. The chlordane did not infure the plants. On newly set tobacco this chlordane spray gare 65 percent reduction of the flea beetle population as compared to 98 percent reduction effected by a DDT spray. All materlals were applied in the plant bed a few hours before the plants were pulled for transplanting.Dominicir $(110)$.

Leptinetarsa decemlineata (Say), the Colorado potato beetle

Chlordane at 2 pints per 100 gallons of water $(0.24$ percent) k1lled 91.7 percent of the larvae 1 day after treatment. Chlordane-DDT emulsion ( 25 percent by weight of each) at 2 pints per 100 gallon of water $(0.03125$ percent of each) killed 92.1 percent of the larvae 1 day after treatment. The results obtained with chlordano were not significantly different from the kills obtained with DDT alono.-Kulash (2?0).

In laboratary tests a 1-percent chlordano dust k1lled 78.3 percent of the adults and 14.7 percent of last 1nstar larvae in 4 days. In greenhouse tests a 1-percent chlordane dust k1lled 91.7 percent of the adults and 100 percent of last instar larvae in 2 days. In field tests a 1-percent chlordane dust killed 88.4 percent of the adults and 100 percent of 3rd and 4 th instat larrae in 2 days.--sun et al. (450).

In laboratory tests chlordane proved only 10 to 15 percent as effective as the gamma 1somer of benzene hexachlorlde when tested on larvae. The 1nsecticldes were applied as dusts and sprajs and the mortal1ty determined after 4 days.--Reucourt (284); Raucourt and V1el (385).

Aqueous sprays of chlordane and DDT applied to potato follage and later infested with third and fourth instar larvae of the Colorado potato beetle showed chlordane to be more tox1c than DDT to this insect.--Kearns et $\underline{\text { II. }}$. $(245)$.

Chlordane proved better than calclum arsenate and almost as good as DDT in Ontar 10 in 1948. These three 1nsecticldes were more effective whon used alone than when mixed with funglcides.-Doyle and Duncan (133).

Phyllotrets strielate (F.), the striped flea boetle

In greenhouse tests \& 1 -percent chlordano dust k1lled 100 percent of adult beetles in $1 \mathrm{day}$. In field tests a l-porcent chlordane dust k1lled 97.3 percont in 3 days and a dust containing 1-percent chlordane plus 0.25 percent rotenone k1lled 100 porcent.--Sun est aㅣ. (450). 
Epllachna Varivestis Muls., the Mexican bean beetle

Dusts containing 2 or 3 percent of chlordane applied to lima beans permitted slight follage injury by the Mexican bean beetle. Sprays containing 1 or 2 pounds of 50-percent wettable chlordane per 100 gallons of water gave similar results.--Huckett (2ㅇ).

A 5-percent chlordane-pyrophyll1te dust at 32 pounds per acre (3 appl1cations) gave 42 percent control of the larvae in tests made at Norfolk, Virginia in 1947.-Brannon (43).

Dust mixtures containing various concentrations and proportions of chlordane and rotenone were tested on larvae of the Mexican bean beetle. According to the loose definition of synergism, the addition of chlordane to rotenone produced a synergistic action.-Sun (445).

In laboratory tests a 5-percent chlordane dust killed only 5 percent of the adults in 4 days and a 2-percent chlordane killed 84 percent of third instar larvae in the same time. In greenhouse tests 2-percent chlordane dust killed 95 percent of third instar larvae in 4 days. In field tests a 3-percent chlordane dust killed 51.1 percent of third and fourth instar larvae after 3 days.--Sun et al. (450).

\section{Unidentified lady bird beetles}

Same as for Eroera post1ca.--Severin (414).

Chlordane was the least destructive of the chlorinated materials to four species of lady beetles.--Newsom et al. (349).

\section{Cucujidae}

Oryzaephilus surinamensis (I.), the saw-toothed grain beetle (332).

A 5-percent cilordane talc dust acted slowly on the adults.-Moretti

\section{Curculionidae}

Anthonomus grandis Boh., the boll weevil

Many tests of chlardane for boll weevil control have been reported: in Alabama by Arant (20); in Louisiana by Gaines and Scales (120), Newsom et al. (347, 350), and Scales and Smith (403); in North Carolina by Kulash (277, 272, 275), and the North Carolina Agricultural Experiment Station (353); in Oklahoma by St1les and Fenton (439), and Brett and Rhoades (46); in South Carolina by Bondy (41), Ife et al. (138), Rainwater (383), and Walker et al. (482); and in Texas by Iry and Ewing (232), and Gaines and 
Dean (164, 167, 163). In several states dusts containing 10 percent chlordane gave boll weevil control eoual to that given by calclum arsenate, prevented bulld-up of ajhids, and killed some weerlls developing in fallea squares. In otiner cases very erratic results have been obtalned. Conflicting results were obtained regarding the practical benefits of lilling weevils in squares and bolls.--U. S. Bur. Ent. and Plant Quar. (466, 46?).

In South Carolina a dust contalning 10 percent of chlordare and 5 percent of DDT, applied at the average rate of 10 pounds per acre - application has been recommended by the state agricultural experiment station for the control of the boll weeril and other insects on cotton.-S. C. Agr. Expt. Sta. (432).

Reports from county agents in South Carolina on the value of chlordane, BHC-chlordane, and toxaphene-chlordane for cotton insect control have been sumrar1zed by Sparks (432).

Anthonomus simatus Say, the strawberry weevil

A 5-percent chlordane dust reduced injury 85.5 percent.--Ohrist and Drigers (27).

A 5-percent chlordane dust gave excellent control of this weevil on strawoerries in Kentucky and doubled the yield.-ny. Agr. Expt. Stz. (258); Ritcher (325).

In New Brunswick, Canada, chlordane proved less efiective than DDT.Haxivel1 (319).

Brachrintnus lifusticl (L.), the alfalfa snout beetle

In several field trlals chlordano appeared promising for alfalfa snout beetle control and proved superior to the standard poanut shell ba1t.Gyr1sco et al. (200).

Brachrihinus ovatus (L.), the strawerry root weevil

A 5-percent chlordane dust, applied at the rate of 10 pounds toxicant per acre to a block of $12-15$ yeal old homloci trees, k1lled all weevils within 3 weeks..-Sciveread (411).

Ceutoriyncus assimilis (Payk.), the cabbage seedpod weeril

In Washington a chlordane dust was inferlor to a 0.5 -percent benzane hexachl oride dust.-- 1 ide (132).

Chalcodermus aepous Boh., the cowpea curcul10

In Texas two applications of a 5-percent chlordane dust reduced the percentape of infested pods on Blacls Eye peas from 15.3 (untreated) to 4.0 , and three applications reduced the infestation to 2.0 percent.- liene (402). 
A 5-percent chlordane at 25 to 30 pounds per acre, apolied 3 times permitted 2 percent of Black Eye pea pods to be infested as compared to 15.6 percent in the check. -Wene (493).

Conotrachelus nenuphar (Host.), the plum curculio

Chlordane in the form of wettable powder, emulsion, and dust has been tested for the control of the plun curculio in Georgia by Snapp (428, 429), and Savago and Cowart (402); in Illinois by Powell et al. (322, 323), Chandler (20-75), and Weinman (482); in Indiana by Marshall (315-312), and Purdue Univ. (376, 378); in Kentucky by Ritcher and Armstrong (397, 257); in New Jersey by Driggers and Darley (114); in New York by Dean (100), and Dewey and Van Geluwe (102); in Pennsylvania by Cox (85); and in Virginia by Bobb (28), Bobb and Grayson (40), and Hough (226).

In general these tests have yielded promising results when 1 pound of chlordane per 100 gallons of water was applied. Chlordane appears superior to lead arsenate, but inferior to benzene hexachloride. Damage to peach foliage and fruit in Virginia by the application of a 40-percent chlordane wettable powder has been reported by Hough (226), but other workers report no injury.

In Ohio in 1949 cage tests involving a study of the speed of knockdown, lethal action, and residual toxicity of 13 or canic insecticides to plum curculio were conducted. Treated peach foliage was exposed to adult curculios at aging intervals of 0,5 , and 10 days under insectary conditions and at 10 days under orchard conditions. The insecticides may be arranged in order of their decreasing speed of knockdown as follows: parathion, ethyl o-nitrophenyl thionobenzene phosphonate, ethyl p-nitrophenyl thionobenzenephosnhonate, tetraethyl oyrophosphate, aldrin, heptachlor, chlordane, dieldrin, toraphene, 2-nitro-1, 1 , bis(p-chlorophenyl) benzene, technical benzene hexachloride, refined benzene hexachloride, and DDT.--Rings (393).

\section{Cylas formicarius elegantulus (Sum.), the sweetpotato weevil}

In the form of bait ( 40 parts ground sweetpotato to 1 part insecticide) chlordane formulations (48-percent emulsion, 50-percent powder and undiluted) gave 7 day mortalities of 88,90 , and 76 percent. Applied as a dust 2-percent chlordane caused 97 percent and 25 percent chlorcane caused 100 percent mortality but also caused some foliage injury when applied to plants in the greenhouse.-Harrison (206).

Tests made in Louisiana in 1948 showed that calcium arsenate applied weekly reduced the infestation of potatoes by the sweetpotato weevil to 1.6 percent; chlordane applied in the soil at planting time at the rate of 5 pounds per acre reduced the infestation to 1 percent; and chlordane in the soil followed by the calcium arsenate treatments at weekly intervals reduced the infestation to 0.2 percent. The potatoes in untreated plots averaged approximately 10 percent infestation. Chlordane did not adversely affect the flavor of the sweet potatoes.--Floyd and Smith (145).

Hypera postica (Gyll), the alfalfa weevil

Adult alfalfa weevils were killed by chlordane ( $3 / 4$ or 1 pound per acre) applied for the control of grasshoppers.--Severin (414). 
Chlordane spray (an an emulsion concentrate) at the rate of 2 pounds of toxicant per acre caused 45 percent mortal1ty in 24 hours, 59 percent in 48 hours and 100 porcent in 14 days. In the plot treated witk chloriane no retardation in the new Erowth or vigor was noted.--liastines and Pepper (208).

Protostronhus sp., ground weevils

Laboratory tests showed that 5-percent chlordane dust at the rate of $0.11 \mathrm{mg} \cdot / \mathrm{sq}$. cm. ( 10 pounds per acre) caused 1 o percent wortal1ty in 72 hours.-Petty (26́3).

Pserdocneorhinus bifasclatus Roelofs, a Japanese veevil

Preliminary tests indlcated that chlorcane was likely to prove more effective than BHC, DDT, or arsenate of lead in controlling this weevil feeding on privet.-Alien (13).

\section{Sitona scissifrons Say.}

In North Dakota in 1947 2-percent chlordane dust proved inferior to 5percent DDT aust in controlling this veevil on peas.--Post et al. (32).

Sitonhilus Eranarius (L.), the granary weevil

In laboratory tests in which the insecticide was dissolved in oil and this solution allowed to spread on filter paper and age 24 hours before placing the keevils on it, chlordane proved less toxlc than DDT. The relative potencies of chlordane with respect to DDT at 95, 50, and 25 percent kill are $0.19,0.50$, and $0.74 .--s t r i n g e r ~(444)$.

The aalults of this weeril proved sultable as test insects for the bioassay of the content of chlordane in oreparations of this toricant. The method consists of exposing the weevils to deposits of the preperrtion and of the pure insecticide that it contains and comparing the median letral denosits.-kíijgsman and Berger (268).

See under Musca domestica.-- Srovn et all. (52).

Trichobaris mucorea (Lec.), the tobacco stalk borer

A 5-percent chlordane dust was more effective than a 10-percent DDT dust in preventing ege laving 3 weeks after the last application. A chlordane spray ( 2 pounds of 50-percent wettable powder per 100 eallons o: vater) was less effective than BHC, but more effective than DDI and torapliene in preventing efE laying. Chlordane was slower than EHC in killing the beetles caged v1th freshly sprayed foliage.-lioodside (511).

Tyloderma fromiae (R1ley), the strawberry crcwa borer

Five percent chlordane dust killed 100 percent of the adults in laboratory tests and gave excellent results in ficld trials.--fitcher (396). 


\section{Dasytidae}

Astylus atromaculatus BI., the Astylus beetle

In laboratory tests 5-percent chlordane dust killed all beetles in 72 hours when applied at the rate of $0.11 \mathrm{mg} / \mathrm{sq}$. $\mathrm{cm}$. (10 pounds per acre)... Fetty $(263)$.

\section{Dermestidae}

Attagenus picous (Oliv.), the black carpet beetle

Woolen cloths irmpegnated with six chlorinated hydrocarbon insecticides at concentrations ranging from 0.5 to 3 percent by weight of cloth were exposed to larvae of the black carpet beetle for 28 days. The following mortalities were obtained: chlordane 75 to 100 percent; benzene hexachloride ( 6 percent gamma) 0 to 100 percent; toxaphene 25 to 52 percent; DDT 15 to 47 percent; TDE 3 to 14 percent; and methoxychlor 1 to 6 percent. According to the visual damage and frass weight noted during these tests, the greatest protection to woolen cloth wes obtained with DDT, TDE, chlordane, methoxychlor, toxaphene, and benzene hexachloride in the order named. Washing and dry cleaning seriously affected the toxicity and the protective value of all the treated clotls, with the exception of those treated with DDT, which resisted one washing at all concentrations.--Iaudani an Marzke (285).

\section{Elateridae}

Aeolus spp., wireworms

The results from one experiment made in Louisiana in 1947 indicate that most of the wireworm injury to fall-planted cane may be prevented by apolying 400 pounds of dust containing I percent of chlordane per acre in the furrow with the seed cane at the time it is planted.--Bynum et al. (63).

Agriotes mancus (Say), the wheat wireworms

Chlordane gave good control at 2 to 4 pounds per acre where wireworm infestations were light but under heavy infestations 4 to 8 pounds were required.--Rawlins ett al. (386).

Seed corn was treated with chlordane at the rates of 4 and 8 ounces of 50-percent dust per bushel. This treatment did not affect the germination, but proved ineffective against wireworms in both laboratory and field tests. Both field plots were severely injured.--DogEer and Lilly (102).

Conoderus vespertinus (F.), the tobacco wireworm

Chlordane was mixed with screened soil, broadcast on the plots, and disked into the soil 3 weeks before the tobacco plants were set out. Where chlordane at 2.5 pounds per acre was used, 55.7 percent fewer plants were injured than in the untreated plots; at 3.5 pounds per acre 70.5 percent fewer plants were injured. BHC was more effective.-Ky. Agr. Expt. Sta. $(\underline{258)}$. 
Whore damage from this insect is expected, add chlordane to transvlanting water at the rate of $1 / 2$ pound of 50-percent wettable chlordane powcer to each 50 gallons of water. Use liberal amounts of water as as to wet the soil all the way to the top of the ridge around plants.- -irettles anc. Lewis (244); Rulash (2206).

\section{Conoderzs spp.}

Sane as for Aeolus spp.--Bynum et al. (63).

\section{Dalooius 2allidus Brow}

Same as For Agriotes mancus.-Dogger and I1lly (109). Drasterius meli1lius (Say)

Same as for Agriotes mancus,-Dogger and Iilly (109). Hor1stonotus uhleri1 Horn., the sand wireworm

Chlordane, 2.5 pounds per acre, proved highly effective in the control of the sand wireworm in large plot tests in 1948 in Louisians.-FIoyd (143).

Chlordane may be mixed and applied witin fertilizer or sand in the row at planting time or broadcast over the field in the fall.-Floyd and Suth (148).

Iimonius ectypus (Say)

In Ontario in 1947 chlordane at 0.25 pound per acre was inferior to the same dosage of BHC. Chlordane was not promising in protecting, potatoes but jave an increased yield of corn.--Armand (24).

A 40-percent chlordane wettable powder at 2 pounds per 100 pounds of sugar beet seeds caused $2 / 3$ of the larvae to be moribund and $1 / 3$ dead in 6 weeks. In another test 1 percent of 50-percent chlordane wettable powder (oased on weight of sugar beet seed) gave poor control. of all chemicrls tested Iindane was the most promising.- - Lange et al. (282).

IImonius mancus (Say)

Same as for Agriotes mancus.--Ravlins et al. (386).

Melanotus comanis Gyll., the corn wireworm

Same as for Aferlote日 mancus.-Dogger and Iilly (109).

Melanotus spp.

Samo as for Aeolus spp.--Dysum et ni. (53). 


\section{Unidentified wireworng}

Chlordane was tested against wireworm in lima bean fields in Orargo County, California. It was applied April 20, 1947, at the rate of 10 pounis per acre and the beans were planted 10 dajs later. In August all treated. plots were better looking than the untreated plots. Ethylene dibromido gave the best control against wireworms and nematodes of all materials tested (DDT, benzene hexachloride, chlordane, and ethylene dibromide).... Crósby (89).

In preliminary tests in California chlordane proved effective for tho control of wireworms when used at the rate of 10 pounds of technical grade chlordane in 20 gallons of solvent (such as benzene) per acre. The material was drilled into the soll to a depth of 6 inches using 12 inch spacings in the same manner as ethylene dibromide.--Lange (281).

In Connecticut in 1947 cillordane applied as a wottable powder by the conventional potato sprayer resulted in ercellent tobacco stands at 5 and $21 / 2$ pounds per acre even in cases in which more than half of the plants in comparable control plots were down. There was no off-taste or impaired burning quailty of cured tobacco leaves secured from these plots. Chlorm dane produced an off-flavor in potatoes but to a macin milder degree than BAC.--Greenwood (225); Turner (461).

Chlordane was inferior to parathion and benzene hexachlor ide in controlling vireworms attacking newly planted sugarcane in Floride. When chlordane was mixed with fertilizer and applied imwediataly, good control was obtained.--Hayslip (210, 211).

Chlordane offers some promise in wireworm control. Apply as a dilute dust to the soil surface and then disc or harrow into the top four to six inches of the soll. Five pounds of chlordane is tho usual dosage..Kurash (276).

\section{Melo1dae}

Decapotoma Iunata Pall., C.M.R. beetles

In laboratory tests 5-percent chlordane dust killed all beetles in 24 hours when applied at the rate of $0.22 \mathrm{mg} . / \mathrm{sq} . \mathrm{cm}$. (20 pounds per acre).-Petty (363).

Epicauta pennsylvanica (Deg.), the black blister beetle

In Indiana in 1946 chlordane proved ineffective against the black blister beetle.--Gould (186). 
Scarabaeidae

Amphimallon majal1s (Raz.), the European chafer

A mixture containine 15 percent of chlordano, 82.5 percent of ethvlene dichlorlde and 2.5 percent "Tween 20 " diluted with water, 5 to $20 \mathrm{ml}$. per gallon per square yard of soll, gave from 12.2 to 21.9 percent control of third-instar larvae of the European chafer three weeks after treatment of the soll plots.--Gambrell and Mason (171).

Anomala oriental1s Waterh., the oriental beotle

Autoserica castanea (Arrow), the Asiatic Earden beetle

Practical control of the oriental beetle was obtained with chlordare at 5.4 and 10.8 pounds to the acre and a mixture of DDT at 13 pounds, and chlordane at 5.4 pounas to the acre. In another test a 50-percent chlordane powder, applied dry with a patented turf duster, in April, at a rate to give 10 pounds of toxicant to the acre on a mixed population, gave full control of the now generation, which consisted largely of orlental beetle larvae, by October.-Adams ( 2 ).

Conostethus 1mpressus (Goldf.)

In laboratory tests 5-percent chlordane dust k1lled only 6.6 to 16.6 percent of the beetles in 120 hours when applied at the rate of $0.22 \mathrm{mg} . /$ sq. cm. (20 pounds per acre).-Petty (363).

Cotinis nitida (L.), the green June beetle

Chlordane at $31 / 2$ pounds per acre, worked into the so1l to a depth of 3 inches, killed 26.5 percent of the grubs and at 5 pounds per acre $1 t$ k1lled 38.9 percent of the grubs. A 5-percent chlordano dust and chlordane spray were ineffective afainst the adults in laboratory tests. - Z Agr. Expt. Sta. (258).

Cyclocephala borealis Arrow, the northern masked chafer

A 5-percent chlordane powder, epplied to soll with a fert1l1zer spreader at rates of 5.4 to 21.7 pounds toxicant per acre, v1rtually el1minated all grubs on a golf course on Iong Island. The chlordane was anplled in May and observations made in October.-Adam (ㅇ).

Popilila japonica Newm., the Japanese beetle

Chlordane is very effective against Japanese beotle larvae and adilts. The princlpal tests of chlordane arinst this beetle have been made in liew Jersey by Fleming $(132,140)$, in Connecticut by Schread $( \pm 05-410)$, and in Maryland by Langford and Squires (284).

In laboratory tests of treated soll analnst third-1nstar larvac I pound of chlordane per acre when freshly applied was as offective as 2y 
pounds of DDT. At the end of 8 weeks in the soil 2 pounds of chlordane were required to equal 25 pounds of DDT. In field tests 10 pounds of technical chlordane per acre reduced the larval population more rapidly and more completely than did DDT at 25 pounds per acre. In these tests the chlordane was apolied as a 5-percent dust to the surface by means of a 3foot fertilizer spreader.--Fleming (139).

All stages of the Japanese beetle in soll are killed by dipping balled or potted plants in an emulsion prepared by adding 1 fluid ounce of the following solution to 10 gallons of water:

Ethylene dibromide

Chlordane (technical)

Cellosolve (ethylene glycol monoethyl ether)

Treen 20

Isopropyl alcohol

\section{Percent by weight}

13.0

6.5

0.5

6.5

67.5

-Chisholm and Mason (26); Mason and Chisholm (218).

Japanese beetle adults may be controlled by a 50-percent chlordane wettable powder used at the rate of 2 teasponns to a gallon of water and applied to vegetation at weekly intervals during July and August. This dosage of chlordane is $1 / 2$ that recommended for DDT.--Schread (405).

Chlordane as an emulsion was not as effective as DDT or benzene hexachloride from the standpoint of either knockdown or residual effect.-Langford and Squires (284).

Aldrin proved more toxic than chlordane against Japanese beetle grubs; 6 pounds of aldrin in 10 days gave greater grub reduction than 10 pounds of chlordane in two weeks.--Schread (410).

In tests made in Connecticut in 1946, 1947, and 1948 chlordane at 8 pounds per acre was effective against Japanese beetles at the end of 18 months.--Schread (409).

In 1949 the U. S. Bureau of Entomology and Plant Quarantine (469, 470) recommended chlordane for grub control where quick action is needed. Chlordane kills the grubs faster than either DDT or lead arsenate. Use 10 pounds of actual chlordane per acre in a dust or spray. A chlordane treatment should last at least 2 years.

Adams and Matthysse (2) of Cornell UnIversity recommend chlordane at the rate of 10 pounds per acre for the control of Japanese beetle grubs. Chlordane acts more rapidly than DDT, killing grubs in from 2 to 3 weeks after application. Indications are that its effectiveness will persist for a least 2 years. 
$\mathrm{Scolyt} 1 \mathrm{~d}=\mathrm{e}$

iylastinus obscurus (Marsh.), the clover soit borer

A 5-percent chlordane dust, applied at the rate of 2.5 pounds of toxicant per acre in May 1947 in liew York, Eave excellent control and a 1-nercent chlordane dust at 2.25 pounds of toxicant per acre gave high control. irone of the insecticides tested as sprays at the rate of 1 pound of toxicant per acre were satisfactory. Chlorcane did not injury red clorer.-Marshall et al. (214).

Chlordane dust at the rate of 2 pounds toxicant per acre gave 46.6 percent non-infested plants as compared to 30 percent in the untreated check. The clover hay at harvest time bore a chlordane residue of 2 D.p.m. Alarin, dieldrin, and BHC gave the best ( 90 percent or better) controls.Gyrisco and Marshall (192).

\section{Tenebrionidae}

Tribolium castaneum (Hbst.), the red flour beotle

Portions of insecticidal dusts, judged to be botween 50 and 100 mF., were applied to counted groups of $\underline{\text { I. castaneum in } 2} 1$ in. specimen tubes. The tubes were gently shaken to distribute tho dust and were then stored under controlled conditions of temperature and humidity until the insects were inspected. The results show that a relatively small increase in concentration of poison in a dust results in a large increase in mortality. Frequently, a fourfold increase in concentration has resulted in a change from a very low to very high mortality. A 0.1 percent chlordane dust killed 99 percent of the beetles in 24 hours at a temperature of $75^{\circ} \mathrm{F}$. and a relative humidity of 70 percent. Chlordane was about 5 times more toxic than toxaphene.--Iord (202).

Tribolium confusum Dur., the confused flour beetle

Larvae are more resistant than the adults to spray residues. EEEs and pupae of the confused flour beetle do not appear to be materially affected by exposure on surfaces that have been sprayed with residual sprays. Imnature stages were exposed for 24 hours to deposits of DDT, chlardane, and gamma benzene hexachloride that had been applied to glass plates at the rate of $50 \mathrm{mg}$. per $1 / 4$ square foot. Eggs hatched almost normally, the average percentage belng 77 after exposure to DDI, 75 for chlordane, and 47 for gamma benzene hexachloride, as compared with 77 percent for the check. A residue of $200 \mathrm{me}$. chlordane per square foot on a glass plate kllled 100 percent of the adult beotles oxposed to 1 for 24 hours in 18 days. The effectiveness of residual sprays decreased with the increase in the absorptiveness of the surface sprayed. Their effectiveness also varied vith the clemical composition of the surface. On corent surfaces the ciuration of effectiveness of all spray doposits was very short. Pretreatment of cement with a sealer, mapnesium-anc-silicofluoride, freatly 1uproved 
the efficiency of spray deposits. On freshly pairted wood surfaces the type of finish influenced the effectiveness of the soray deposit. Coldwater and flat oil paint ereatly reduced the effectiveness of the spray deposits but enamel did not. Water suspensions of wettable powders were absorbed less than other Iormulations, so that on absorptive surfaces, such as cement and cardboard and unpainted wood surfaces, they were more effective.--Cotton and Frankenfeld (81); Cotton et al. (83).

Chlordane formulated as an emulsion was sprayed on varlously treated rood surfaces and flour beetles were exposed to the residues (200 mg. chlordane per square footl for 6 hours. The mortality of the beetles 12 days after exposure was 100 percent on the unpainted surface, 30 percent on cold-water paint, 20 percent on flat oil paint, and 60 percent on enamel.--Cotton and Frankenfeld ( $\underline{82}$ ).

See under Musca domestica.--Brown et al. (52).

See under Blattelia germanica.--Brown, Wenner, and Park (53).

\section{IPPIDOPTERA}

Aegeriidae

Melittia cucurbitae (Harr.), the squash borer

In experiments at Geneva, New York, control of the borer was obtalned with a 5-percent chlordane dust.--Corruth and Fowe (66).

Sanninoidea exitiosa (Say), the peach tree borer

In tests made in Virginia in 1947 and 1948 chlordane at 1 pound per 100 gallons of water was not so effective as DDT and had a relatively short period of residual killing.-Bobb (39).

\section{Crambidae}

Dia.traea saccharalis (F.), the sugarcane borer

In Iouisiana in 1946 poor control ( 51 percent) of the borer was obtained with a 5 percent dust of technical chlordane.--Ingram et al. (236).

In 1947 chlordane accounted for a significant increase in borer infestation following second generation dusting, due apparently to its injurious effect upon the natural enemies of this pest. At one location in Ioulsiana chlordane caused a loss in yield of 6.65 tons of cane per acre.--Dugas et aI. (112). 
Lymantri1dae

Euprectis terminelis (Walk.), the pine brown tail moth

In laboratory tests a 5-percent chlordane dust applied at the rate of 10 and 15 pounds per acre was less effective than DDT, toraphene, and lead arsenate.--Petty $(\underline{363})$.

\section{Olethreut1dae}

\section{Carpocass pemonelia (L.), the codling moth}

In IIlinois in 1946 one pound of chlordane per 100 Eallons of water, e1ther as a 50-percent wettable powder or as an emulsion, proved less effective than lead arsenate or DDT in controlling codling moth on apples.-Weinman (486).

An emalsion of chlordane ( $150 \mathrm{~g}$. chlordane and $500 \mathrm{~g}$. white oil in 100 l1ters of water) was almost as good as DDT ( 88 percent efficacy as compared to 95 for DDT) in the control of codling moth larvae on apples in France in 1947. There was no phytotoxic action.--Frezal (157).

Chlordane, 2 quarts of 20-percent concentrate in 100 gallons of water, proved less effective than lead arsenate agalnst the codling woth in Virginla.-Hough and Hill (227).

In Indiana Steiner et al. (438) in 1948 reported that chlordane has proved of little value for use in control of the codling moth or other apple insects.

In tests to control the codling moth attacking Payne walnuts in northern California chlordane was found not only to be ineffective, but its use resulted in a marked increase in the codling moth infestation, which exceeded that which occurred in the unsprayed trees. One spray of chlordane, 0.5 pound per 100 gallons of water in 1946, resulted in 14 percent of the nuts being inferted as compared to 7.05 percent infested in the check.-M1chelbacher and Middlekauff (322).

Grapholitho molesta (Busck), the ariental frult moth

Field testa on peaches in New Jersey showed chlordane to be inferior to parathion when applied as spray for the control of second and third brood oriental fruit moth.--Drikgers and ierrill (115).

In Virginia in 1947 chlordane was not effective in killing oriental fruit moth adults. Spray residues of the insecticide, hovever, were extrenely toxic to Macrocentrus parasites and residual killing was noted for several weeks after application under favorable conditions.--bobb (38).

Infury by third brood moths reached outbreak proportions in peach orchards in Rentucky where chlordane had been used. Bacterlum grun 1 seriously affected 17.1 percent of the frutts in chlordano spreyod plots, 
and only 3.2 percent of the fruits in plots sprayed with the standard lead arsenate schedule.--Ky. Agr. Expt. Sta. (258).

Polychrosis botrana (Schiff.)

In France in 1947 chlordane was tested as an emulsion ( $150 \mathrm{~g}$. chlordane, $500 \mathrm{cc}$. petrole, $10 \mathrm{~g}$. emul sifier and 100 liters of water). Its efficacy according to Abbott's formula was 80 as compared to 85.9 for DDT.Frezal (157).

\section{Polychrosis iteana (Clem.), the grape berry moth}

In tests made in the Erie grape belt of Pennsylvania a spray of chlordane (as a 50-percent wettable powder) at 0.75 pound of toxicant per 100 gallons of water was not effective and severely burned the follage of the Concord grape.-Cox ( 44$)$.

\section{Phalaenidae}

\section{Phalaeninae}

In tests made at Charleston, South Carolina a 5-percent chlordano dust, apolied at the rate of 20-25 pounds per acre-application, was fairly toxic to the cabbage looper and Agrotinae, but relatively ineffective against the imported cabbageworm in two spring tests and one fall test. A 3-percent chlordane dust was not very toxic to either the looper or the imported cabbageworm in two spring experiments. A chlordane suspension spray and an emulsion spray gave good to excellent reductions of the looper and imported cabbageworm and were superior to a 3-percent chlordane dust when applied at comparable dosages of active ingredient. This dust mixture did not have good dusting qualities. Chlordane dusts usually proved inferior to DDT dusts of comparable strengths. No plant injury was noted from the use of chlordane on cabbage.-Reid and Cuthiert (387).

Arotis orthosonia Morr., the pale western cutworm

Chlordane dissolved in benzene-heroseno mixture and applied in a spray tower was moderately toxic to the larvae.--Brown et al. (50).

Agrotis zpsilon (Rott.), the black cutworm

A bait containing 1.5 percent of chlordane, 5 percent of xylene, and 11 percent of oil in bran killed 67 percent of the cutworms after 48 hours in Iaboratory tests.--Brooks and Anderson (뇨).

A 5-percent chlordane dust, applied to fields in North Carolina at rates of from 20 to 100 pounds per acre, was of little value. Irish potatoes grown in chlordano-treated soil showed no off-flavor.-Kulash (278). 
Ant1cars1a gemat1118 Giond, the pelvetbean caterp1ller

A Iow concentration of chlordane showed some orcmise for the control of this insect in Louiblena in 1946, but the noxt jear it gave rery little control after f1ve days.--Dugas et al. (126, 128).

A 1-percent chlordano dust was 1688 effect170 than 1-percent DDI and 1-percent gama benzene hexachlorlde dusts in controlling caterp1Ilars on alfalfa 1n Alabama in 1946. All dusts wore applied at tbe rate of 15 pounds per acre. In 1947, 5-percent chlordane dust gare 68 percent control of the larvas on soybeans 48 hours after dusting at the rate of 25 pound per acre.-arant (2l).

C1rph18 un1puncta (Bar.), the armowarm

In preliminary laboratory tests chlordano was mach loss toxic than DDP.- - B18hopp (32).

Bel10th18 armigera (Bbn.), the tomato fmitworm, the bollworn, the carn earworm

A field test on tomatoes made in Lou1siana in 1946 showed 2-percent chlordane dust to be inferlor to cryolite and calc1um arsenate.-Flod (141, 142).

A 5-percent chlordane dust gave controls of 41.6 and 38.7 percent in tro testg on western Long Island in 1948. The effectiveness of chlordane was less than that of DDT, TDE, pareth1on, or methodgchlor.--Butler and Carruth (62).

Dusts contalning 5, 10, and 20 percent of chlordane falled to glve adequate control of the boll worm.-Arant (으); Kalash (27l).

In laboratory and cage tosto in Texas a 20-percent chlordane dust was legs effective against the bollworm than DDT or toxaphene.-Ir and Iuing (232).

In Texas during 1947 a 20-percent chlordane dust was as offective as calc1um arsenate, but 108 s effect1re then a 20-percent toraphene dust ar a 5-percent DDI plus 3-percent gamma benzene berachlor1do sulfur dust in controlling bollworm. Gaines and Dean (164).

An emulg1on of chlordane atomized on corn ears showed promise agalnst the carn earworm.--B1shopp (32).

In Horth Carolina in 1947 a 5-percent chlorcane dust gave 40.4 percent clean ears as compared to 75.5 percent clean ears result1a from the use of 0.25 percent DDT $1 \mathrm{n}$ mineral o11. Of the untreated ears 27.0 percant were clean.- Kulash (223).

In Florida in 1947 a 5-percent chlordan dust and a 50-percent chlardane wottable powder at 2 pounds per 100 gallons of water vere 1 aferlor to DDr and mothoxychlar dust and sprays in controlling oarwores on sweetcorn.Kol heimer (249). 
In the Etergiades area of Florida a 3-percent chlordano dust gavo 6 percent of ears with no worm damage; a 5-percent DDT dust gare 39 percent; and 2.7-percent DDT in oll gave 100 percent. \& 40-percent chlordano emulsion, I quart to 100 sallons of water, was about equal to DDT emulsion, but loss affectipe than parathion ( 2 pounds of 15 percent wettable per 100 gallons of wetar) in preventing tometo injury by the tomato frultworm.-. Eisysip (211).

In laboratory tests 5 percent chlordane was slightly less toxic than DDT, natural cryolite, or 2 percent parathion.--Petty (363).

A 1-percent solution of chlordane in refined wineral oil (Saybolt $\nabla$ iscosity 185-195 sec. at $100^{\circ} \mathrm{F}_{\text {.) }}$ injected into tips of ears of Golden Cross Bantam sweet corn in southern California vas slightly less effective than 1-percent DDT and TDE oolutions. These materials all gave good conirol when applied as high pressure aerosols.-manderson and Hashe (18).

In Louisiana in 1948 chlordane dust, applied 8 tims at an arerage dosage of 12 pounds of dust per acre per application, failed to control insects on Mexican June corn planted Augast 13. The plants were more than 50 percent destroyed and no ears were produced.--Floyd (144).

A 5-percent chlordane dust gave less than 50 percent worm-free ears in tests with sweet corn in North Carolina. Cotton treated with 5 percent chlordane was as bearily infested with bollworms as untreated cotton.-N. C. Agr. Expt. Sta. (353).

In the Lower Rio Grande Valley of Texas a 5-percent chlardane dust ( 4 dustings at weekly intervals) gave 45 percent earworm injury as compared to 79 in the untreated plants. A spray of 4 pounds 50-percent wettable chlordane per 100 gallons of water gave 2-percent whorls with live larvae compared to 45-percent in the untreated.--Hene and Blanchard (495).

\section{Heliothis enonis (Schiff), the flax bollworm}

Chlordane dissolred in benzene-kerosene mixture and applied in a spray tower had very slight effect on the larvae.-Brown est al. (50).

Iaohygma frugiperda (J.E. Smith), the fall armyworm

A 5-percent chlordane-pyrophyllite dust, applied 3 times to a total of $281 / 4$ pounds per acre, gave a control of 98 percent of armyworms after 72 hours. A bait containing 1.5 percent of chlordane, 5 percent of zylene, and 11 percent of oll in bran killed 100 percent of the armyworms after 24 hours in cage tests, and 93 percent after 48 hours in field tests. Chlordane dust falled to control late fourth-instar larvae.--Brooks and Anderson (48).

In tests ade on field corn at Norfolk, Virfinia, in July 1948, a 3-percent chlordane dust reduced the number of worms 57 percent below the check in 24 bours and increased the percentage of uninfested plants above 
the check 46 percent in 24 hours and 61 percent in 48 howrs. In another test in a pasture a 5-percent chlordane dust k1lled 62 percent of the aryvorms. Parath1on and DDT gave the best control.-Bofmaster and Greerwood (225).

Five percent chlordane dust was feirly offective in controlling the ardororm bat affected the corn adversely.--T1sot and Eultert (456).

Cblordane dust was effective agalnst this insect on tomatoes in For1da.--Zelsbe1mer (248).

Far tho control of this insect attacking lams in Florida it 1. recomended to use 2 pound of 50-percent chlordane vettable powder per 100 gallons of water per acre or a 5-percent chlardane dust.-Kelshelmer (253).

Chlordane, applied as an emulsion to corn ears, liperted an odor not1ceable at harrest time. Dusts gare unsat1sfactory control, but cblardawe emalsion ( $1 \mathrm{ml}$. plus $0.5 \mathrm{ml}$. of emulsifler, $20 \mathrm{ml}$. of white mineral 011 and water to make $100 \mathrm{ml}$.) gave cons1stently good control of tris specles and the corn earrorm in suetcorn..-Blanchard and Chamberlin ( 35 ).

Chlordane wettable pordar (50-percent) at 2 pounds per 100 gallons of water gave good control of fall arufworms in the buds of corn. $A$ polsoned wheat bran contalning 5 percent of chlardano also gere good control.--Heysilp (210, 211).

A 5-percent chlordane dust, applied at the rate of 10 pound per acre to Ladino clover, kllied I/2 the larvae two days after dusting. \$o phytotordc1ty was observed.--Kulash (224).

See also ander "Unidentifled ente".- Kelsheimer (252).

Perldroma margar1tose (Haw.), the variegated cutvorm

In prelimary leboratory tests chlordane was much less toxic than DDT. -B1 shopp (22).

Platysente sutor (Gn.)

A 5-percent chlardane dust k1lled 24.2 percent of the larrae on celery 1. Florida in 24 hours.-- Haysip (211).

Prodente erldanta (Cram.), the southern armororn

In laboratory test a l-percent chlordano dust k1lled 96.7 percent of medium larvao in 2 days.--Sun et al. (449, 450).

In funigation action against larvae chlardane was superiar to gamaBHC and DDT, but in contact action and stomach action it was infer1ar.-Sun et 요. (448). 
Proden 1a 11tura (F.)

On fourth-instar larvas chlordane was almost as toxic as was DDT (83.3 percent mortality as compared to 95 percent for DDT after 48 hours).Erezal (152).

Trichoplusia ni (Hon.), the cabbage looper

In fleld tests a 3-percent chlordane dust k1lled 62.6 percent of the larvae in 3 days, and a dust containing 1 percent chlordano plus 0.25 percent rotenone 52.7 percent.-Sun et al. (450).

In Iaboratory and cage tests at Vaco, Texas, during 1946 a 20-percent chlordane dust was less effective than toxaphene.-Iry and Bwing (232).

Same as for Pieris rapae.-Dills and Odland (105).

Unidentified species of cutworms

When fields of grain, grass, or alfalfa were sprayed or dusted with $3 / 4$ or 1 pound of chlordane per acre, many specles of cutworms were killed... Sererin (414).

To control cutworms in a prepared seedbed apply about 30 to 40 pounds of 5-percent chlordane dust per acre.-Granorsky (194). Serv. (423).

Older cutworms are not controlled by chlordane.--U. S. Dept. Agr. Ext.

Chlordane dust is recomended for control of cutworms attacking sweetcorn in Florida.- $\mathrm{Kel}$ shoimer et al. (256).

\section{Pleride}

Colias philodice eurytheme Bdv., the alfalfa caterpiliar

A 5-percent chlordane dust at the rate of 1.25 pounds of toxicant per acre reduced the number of caterpillars 52.8 percent in 48 hours and 65.3 percent in 96 hours.--Smith and Allen (427).

Pleris rapae (I.), the imported cabbage worm

In 1946-1948 a 3-percent chlordane dust gave 72.6 percent control, proving inferior to DDT anc TDE.-Dills and Odland (105, 107).

In a fleld test chlordane dust proved superior to benzene hexachloride.Brooks and Anderson (쇼).

In laboratory tests a 3-percent chlordane dust k1lled only 5.6 percent of last instar larvae in 2 dajs as compared to 79.2 percent killed by a 3percent technical DDT dust. In field tests a 3-percent chlordane dust 
k11led 59.4 percont of the larrao in 3 days; a 3-percent DDT dust killod 79.5 percent; and dust contala1ng 1 percent chlordane plas 0.25 percent rotenone k1lled 85.1 percent.--Sun et al. (450).

\section{Pog ch1dae}

Acanthopsyche funed Heyl, the wattle bagwore

In laboratory tests a 5-percent dust of chlordane, appliod at the rate of 5, 7, 9, and 10 pound per acre, was markedly more elfective than natural cryol1te against first and second Instar basworm when applied to the leaves only or when both leaves and vorms vere dusted. Chlordane appeared to be sl1ghtly 1088 effective than benzene herachleride against the 11rst two Instars, and was lese effect1re than cryol1te for the older bagworms.--Petty (364).

\section{Phyc1t1dao}

Acrobag1s caryae Grote, the pecan mat casebearer

Chlordane 44-percent emalsion concentrate at 1 quart per 100 gallone of vater, applied late in the summer, Contral Teras, in 1947, ras less eflective than DDI or lead arsenate in preventing nut casebearers from golng into vinter quartere.-Fickels (25I).

Elasmophalpus Itenosellus (Zell.), the lesser cornstalk borer

In Loulsiana chlordane at the rate of 2.5 pound per acre prored much more effective than 10 pounds of DDT and produced a nearly perfect atand.-Dugas et al. (120).

Fohest1a kohn1ella Zell., tho Mediterranean flowr moth

See ander Kasca domest1ca.-Brown et al. (52).

Romalopalp1a dalera Dyar, the papaja webworm

A spray of 0.05 percent chlordane reduced the percentase of webs with larvae to 14.4 as compared w1th 81.7 in the chock 7 dass after treatjent, but 36 days after treatment the percontages were 30.4 and 44.6 , respectively.-Wolfenbarger (502).

Pyraust1dao

Desn18 funeral1g (Hoвn.), the grapo leaf folder

In California in 1947 a dust, containing 5 parcent of chlordane and 50 porcent of sulfur, was 18 ss effect1ve (9 and 27.4 larras in rolls per 
Vine in two tests) than a 50-percent cryolite, 5-percent DDT, and 40-percent sulfur dust ( 1.6 and 2.4 larva in rolls per vine). The untreated check vines contained 35.8 larvae in rolls per vine.--Arazier and Barnes (154).

Loxostege similalis (Guen.), the garden webworm

In barrier and dusting tests a 5-percent chlordano dust gave the most promising results.- walt on ( 483 ).

In laboratory and cage tests at Waco, Texas during 1946 a 20-percent chlordane dust was less toxic than toxaphene, but the results were considered promising.--IFy and Euing (237).

See under "Unidentified ants".--Kelsheimer (252).

Phlyctgonia rubigalis (Guen.), the celery leaf tier

In preliminary laboratory tests chlordane was mach less taxic than DDT.--Bishopp (22).

Praugta gubilal1s (Fbn.), the European corn borer

Chlordane dust was promising in tests made in Maine but was not so effective as DDT and Hania.--Hawkins and Thurston (209). (513).

Chlordane spray gave excellent control in Ontario in 1947.--Wressel.

\section{Sphingldao}

Protoparce quinquemaculate (Haw.), the tomato hormorm

P. sexta (Johan.), the tobacco hornworm

Chlordane prepared as a 5-percent dust gave 73 and 30 percent kills, respectively, of these two species on tomato, while a 2-percent dust gave 91 and 43 percent kills. Chlordane in oll emulsion-form at 1:800 gave an excellent, but slow kill on the hornworms with 84 percent kill for sexta and 80 percent for the other species.-Gould $(185,182)$.

A 5-percent chl a.dane dust was the only material that controlled full grown larvar of $\underline{P}$. quinquemaculata on tomatoes in Flor1da.-Kelsheimer (248).

In Ontario chlordane was less effective than DDT which gave good control of the tomato hornworm even at 0.72 pounds per acre.-Fox et al. (153). 
In Oregon a 5-parcent chlordane dust, applled to blackberrlex, gare 41.1 percent control; a 5-percent TDE dust gave 100 percent control. In another test a 5-percent chlordane dust gave 33.6 percent control - the poorest of all lnsecticides tested. A spray contalalng 4 plats of chlordane exulsion ( 44 porcent chlordane) per 100 gellons of vater gave 86.1 percent control wich was 1ncreased to 91.4 percent when 4 quarts of o1l were added to the spray. TDE gare the best control of the sprays tested.Rosenstiel (292).

A chlordane spray (1 quart of 44 percent emals1on per 100 gallons of water) gave good control of the larvae of red raspberries in tho Payallap Valley, Washlngton, but exhlbited phytotoxic1ty causing a goneral jellowing of the follage. A wettable powder appeared to be safe.--Johansen and Breakey (242).

Argyrotaen1e Felutinana (Wkr.), the red-banded leaf roller

Chlordane, 1 pound of 40-percent wettable powder per 100 gallons of water, proved uneatisfactory for the control of the first brood leas rollor In a Maryland apple archard.--Graham (191).

In New York in 1948 chlordane as a 50-percent vettable powder proved worthless against second brood.-Glass and Chapman (129).

Chlordane is ineffective.--Rings (322). Chor 18toneura fumperane (Clem.), the spruce budworm

Chlordane dissolved in benzeno-kerosene mixture and applied in a spraj tower had very ol1ght effect on the larvao.--Brown et al. ( 50 ).

Cnephasle longana (Haw.), the omiverous leaf tier

Chlordane, 1 quart of 46 percent emulsion per 100 gallons of weter, gave negliglble kill of tho caterplliars on fleld gorn asters at Palo Alto, Cal1fornia.--Pritchard et al. (324).

\section{EYMENOPTERA}

\section{Apldar}

Ap18 mell1fers I., the honey bee

The effect of chlordane on the boneybee has been observed in Callfornla by ickart (122-124) and I1nsley and MacSwain (300); in Massachusetts by

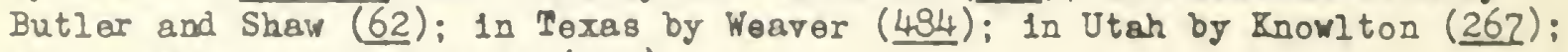
and in Washington by E1de (132).

Laboratory tests by Eckert (123) proved that chlordane 1s highly toxic to bees as a stomach polson, contact Insect1c1de, and 88 a fumigant. When chlordane is fed to bees in a 20-percent sugar slrup, the approximate LD-50 1 i 1 microgran per bee. The residual action extends over a perlod of 3 or moro weeks under laboratory conditions. 
Later results by sckert (124) showlde the comparative toxiclty of the newer insecticides to bees are presented in the following table:

Table 1. - The toxlc efiect of certain choricals on honeybers

Chemical

Benzene hexachloride

(90\% gamma 1somer)

Chlordane

Aldrin

TDE

DDT

Hexaethyl tetraphosphate

Parathion

Tetraethyl pyrophosphate

Toxapheno
ID-50 in 72 hours, micrograms per bee

$$
\begin{aligned}
& 0.15 \\
& 1.21 \\
& 0.25 \\
& 16.0 \\
& 4.6 \text { (room temp.) } \\
& 12.0+\left(95^{\circ} \mathrm{I} .\right) \\
& 0.29 \\
& 0.07 \\
& 0.75 \\
& 22.0
\end{aligned}
$$

Eckert also observed that chlordane dusts have reduced the field force of colonies by from 50 to 80 percent when applied to alfalfa in bloom. Chlordane in oil ( 2.5 percent solution) caused the loss of brood and a portion of the bees when applied in hot weather as an oll spray to grass in front of 30 colonies. A quick removal of the affected colonies prevented much heavier losses. The bees apparently pulled the fumes through the hives by their ventilating operations.

The walls of a comb room were sprayed with a 5-percent chlordane suspension in water for the control of ants and one year later enough chlordane vapor was present in the room to kill bees wathin 36 hours.-- Ifekert and West $(125)$.

In laboratory tests bees in cages were dusted with a pre-determined dose of insecticlde at 40 pounds pressure. The dust was allowed to settle for 30 seconds after which the bees were immedlately transferred to other cages for observation. The toxic1ty of 10 percent chlordane-40 percent sulfur varled greatly with the temperature. At temperatures below $76^{\circ}$. chlordane was only slightly toxic, the MD oeing 29.95 pounds per acre, but at $86^{\circ} \mathrm{F}$. 1ts toxicity increased greatly.-Wearer (484).

Chlordano does not repel bees, but is very toxic to them if applied while they are active in the field and remains toxic from 12 to 48 hours following its application depending on weather conditions. There 1s less damage to bee populations from chlordane when used as a spray than when used in the form of a dust.--Mont. Agr. Expt. Sta. (331).

\section{Cephidae}

Ceohus cinctus Nort., wheat stem sawfly

A 5-percent chlordane dust at 20 pounds per acre permitted an aver- 
ape 1afestation of 65 percent as compared to 68 percent in the check plot.-. Murro et al. (338).

\section{Form1c1doe}

Camponotus herculeamug pennsylranlcug (Deg.), the black carpenter ant

Cblordane $1 \mathrm{~s}$ effect1ve as a 5-percent dust and as a 50-percent wettable powder, using 4 ounces of toxicant per 1,000 gquare feet.-achread and Chapman (412).

Formica exsectoldeg Forel, the Allegheng wound ant

The application of a 50-percent chlordene wettable powder at low dosage levols k1lled adults in 5 to 6 hours; eggs did not hatch and pupao produced no adults.--Schread and Chapman (412).

Formica fusca var subser1ces Say, tho 811 kg ant

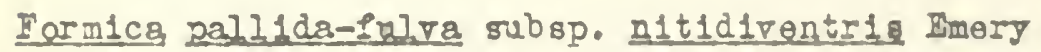

Chlordano controlled these ants working in open soll at the base of shrubs and in turf.--Schread and Chapman (412).

Ir 1dowyrmex hum111g Mayr., the Argentine ant

Chlardane dust was repellent to the Argentine ant for a considerable perlod of time. It makes an excellent barrler around thelr nests or when sprayed on the walls of. a building or foundation of a house. Ants that come in contact with the dust lmmedlately withdraw and soon disappear from that 1mediate area.-Dickert (123).

Diosel oll contalning 2 percent of chlordane controlled Bermuda Eass and Argent1ne ant around beeh1res in Californta whout causing not1ceable loss of boes. Both grass and ants later cam back into the treated area.Ickert and Hest (125).

Las1us niger allenus amerlcanug Emery, the cornfield ant

One pound of 50-percent wettable chlor dane por 1,000 square feet caused a 100-percent reduction in ant hills after 30 days.-- Korr (259).

For the individual spot treatment, one-olghth of a teaspoon of 50percent wettablo chlordane powder 18 placed in the center of each hill and watered thoroughly into the nest,using a four-gallon pressure spraper with tire spray nozzle removed, or using a waterlng can with the spreader remored. For the complete turf treatment, the ent1re area $1 \mathrm{~s}$ 1mpregnated w1 th the material. The 50-percent wettable powder applied at the rate of four ounces to 1,000 square feet was found to be desirable from the standpoint of the oconomic and tho residual value of tho insecticide. The turf 18 then watered with 50 to 60 gallong of water to 1,000 square feet to obtain maxim 
penetration. This treatment has destroyed all ants and has given complete protection from reinvasion for a period of four to six weeks.-Schread (406); Schread and Chapman (432).

Lasias nigar var. neoniger Bmery

Same as for I. niger alienus americanus.-Schread and Chapman (4I2).

Monomorium minimum Buckl., the little black ant

Tests at the Savannah laboratory of the Bureau of Intomology and Plant Quarantine have shown chlordane to be less effectire than DDT as a residual treatment, although in actual practice it has been reported to be highly effective in controlling ants in homes.--inipling (265).

Pogonomrmex badius (Iatr.), the Florida harvester ant

Colonies in a typical Texas Gulf coast pasture in Florida were tneated with a 5-percent chlordane dust. The treatments were made by applying approximately one ounce of the dust over the mound around tho entrance to the nest by hand in such a manner that the ants leaving or entering the nest would have to pass through the insecticide. Each nest was treated fire times during the test. At the end of 83 days no colonies had been eradicated.-Riherd (390).

A chlordane residue of 1.3 micrograms per square centimeter killed 30 percent of the ants in 120 hours.-Metcalf (223).

Pogonorvrmex barbatus var. molefaclang (Buckl.), the Texas harvester ant

More than 300 colonies in pastures and yards in Oklahoma were destroyed by pouring one cup (about $200 \mathrm{ml}$.) of 3-percent chlordane solution into the opening of each colony. Carbon tetrachloride and 95-percent alcohol vere satisfactory solvents. Other diluents such as petrolen oils or water suspensions have since been found to serve as well. -Brett and Bhoades (44).

Solenopsis geminata $(F$.$) , the fire ant$

Same as for $\underline{M}$. minimum.--Innipling (264)

Solenopsis saev1ssima var. Ilchteri Forel, tho imported fire ant

In Mississippi in 1947 chlordane was effective in laboratory tests and in treating mounds in the field. A 5-percent chlordane dust was ruch more effective than a 10-percent DDT dust.-Iyle and Fortune (304).

In Alabama the most effective treatment of individual ant hills was opening the mound and mixing insecticide with the soil in the mound. Onehalf pint of 2.5-percent chlordane emulsion spray or 2 ounces of 10 percent dust was highly effective when applied in this manner. Above 90 percent control of fire ants was obtalned on area treatments whon 2 or 4 pounds of chlordane as dusts or emulsion sprays was disked into the soil. Considerably 
loss control resulted from dusts when the soll was not d1sked. Whether the dust was aplled prevlous or subsequent to disk1ng appeared to be of less 1 mortance than thoroughness of disking. Mmalsion sprays were almost as effective without disking as when disking was done.--Edon and Arant (129).

Tetramorium coosp1tun (I.), the parement ant

Chlordane does not have the disadrantage possessed by DDT of belng detected by ants, and they readily crose an area treated w1th 1 t and so are destroyed. The simplest method of usin solut1ons of chlordane is to apply 1t with a cheap palnt brush. Paint a band about six 1nchos wide around the kitchen and pantry, and around any other ereas known to be frequented by the ants. In experimental work some benefit has been der17ed in control of grease-1ov1ng ants by placing small contalners of attractive materials such as peanut butter or chicken fat on the floor, and then palnting a band of chlardane solution around the lure. Chlordane solut1on,forced under the baseboard by an automoblle force oller, controls the parement ant and also larrae of the carpet beetle. Chlordane should be painted alcng the foundat1on 8111 so that the ants have to cross the treated areas.- $-5 c h m 1 t$ ( 404 ).

Wasmannia auropanctata (Roger), the little fire ant

Chlordane spray at 0.05 percent reduced the number of 11 ttle f1re ants to 4 per I1near foot of guava tree trunk 3 days after appl1cat1on and 0.10percent and 0.50-percent sprays reduced the numbers to 2 and 0 . The number of antg was st1ll zero 54 days after the appl1cation of the 0.50 -percent chlorciano spray and a spray of DDT, 3 pounds of 50-percent wettable per $100 \mathrm{gallons}$ of water.-Wolfenberger (507).

Chlordane spray was prepared by d1ssolv1ng 8 ounces of the technical Erade of the toxicant in one-half gellon of Number 2 fuel o1l, add 1 ag 19 ml. of phthalic glyceryl alkod resin to make a stock emulsion, and then dilut1ng the emlsion with water to make 100 gallons. The spres was applied thoroughly w1th a power outf1t to the tree trunks and larger lower branches.

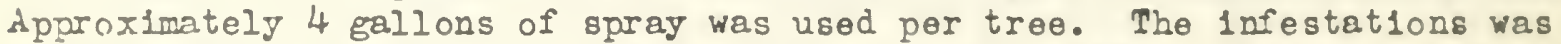
sleniflcantly reduced for a perlod of at least 12 weeks. Number 2 fuel o1l alone at a strength of 0.5 percent was of no value.-0aburn (354).

Un1dent1fled ants

As a spray, as a dust, or mixed with fert1lizer, chlordane flres excellent control of ants at rates as low as one pound to the acre. It may also be used as a ba1t.--Kol shelmer (252).

In Forida a 2 1/2-percent chlordane dust resulted in 90 to 95 percent control of the common species of ants found in groves in the centrel part of the state: a 5-percent dust destroyed all treated colonies. A dust contalning 2 1/2-percent chlardane and 10-percent DDT has also resulted in 100 percent control of ant colony. The best method of kllling out a colony of ants around the base of a tree 18 to mix a small amount of chlordane dust with tho top inch of soll whore the ants are working and then sprinkle 
an additional amount over the top of the soil and around the base of the tree. The leaf eating or agricultural ants can be controlled by sprinkling the chlordane dust over the whole surface around the entrance to the nest.Thompson and Griffiths ( 454 ).

A 2-percent spray of chlordane was recomended by the $U$. S. Bureau of Entomology and Plant Quarantine (47) in August 1949 for the control of ants. Apply it directly into cracks or opentnes from which ants are emerging, and onto the surfaces immediately surrounding those openings. Then they will have to crawl over the deposit of insecticide that remains. Chlordane spray can also be applied directly to the nosts of ants.

A mixture of lindane and chlordane has been suggested to accomplish both quick kill of ants and to have long-lasting residual action.-moffaletti (457).

\section{Tenthredinidae}

Macrocentrus ancylivorus Roh.

See under Grapholitha molesta.--Bobb (38)

\section{DIPTERA}

\section{Agromy zidae}

Ilrlomyza flaveola (Fall.), the serpentine leaf miner

A 5-percent chlordane dust gave the most effective field control of this insect attacking tomatoes in Flor1da.- Kelsheimer (248).

Sprays containing from 1 to 2.25 pounds of chloroine per 100 gallons and a 5-percent chlordane dust ( 7.5 pounds toxicant per acre) gave satisfactory control of this insect on fleld grown asters in southern California.Jefferson and Pence (239, $\underline{240}$ ).

Chlordane 50-percent wettable powder at 2 pounds per 100 gallons of water was inferior to parathion and toxaphene against the serpentine leafminer attacking tomatoes in the Florida Everglades.-Hayslip (2l2).

In a large plot test in southern Florida in 1947 chlordane emulsion (81 percent) at 2.3 pounds toxicant per 100 gallons of water gave 97 percent control of the serpentine leaf miner on potatoes.--Wolfenbarger (508).

Iirlomyza orbona (Neig.), the pea leaf miner

Five applications of a 5-percent chlordane dust, applied by means of a power driven duster at the rate of 26 pounds per acre for each application, gave 98 percent control. Laboratory tests using known deposits of chlordane, benzene hexachloride, DDT, and hezaethyl tetraphosphate indicated that chlordane was the most effective, killing 100 percent of the adult flies in 16 hours with a dosage of 2 micrograms per 10 square inches of surface.-Iange and Smith (283). 


\section{Callphoridae}

Call1treze americane (C. \&. P.), the screw-worm

Chlordane is amone the most effective insecticides tested against screw-worm larvae.-U. S. Bur. Ent. and Plant quar. (468).

Callitroga macellaria $(F \cdot)$, the secondary screw-korm

Phormfa regina (Me1g.), tho black blow fly

At Kerrville, Texas, in 1947 shoep were infested by 1mplanting the sewly hatched larvae of several blow flles, principally these specles on a very small plece of ground beef which had been rubbed into the wool on the animal's rump. On elther the second or third dav after 1mplantation, depending on weather conditions and the development of the larvae, the infestation was treated. Each of the chemicals was usod at a concentration of 2 percent. Chlordane and tho gamm isomer of benzene bexachlorice (83 percent pure) protected sheep against reinfestation for relat1vely lonf perfods of time, but in these tests neither remained effectire as long as toxaphene.--Graham and Eddy (193).

\section{Phorm1e spp.}

Chloraane is effective in protecting sheep from fleece worm attack.Bishopo and Knipling (出): Laake (280); U. S. Bur. Ent. and Plant quar. (468).

\section{Cecidom 11dae}

Phytophaga destructor (Sry), the hessian fly

Chlordane dust wав applied by airplane in September 1947 to Col orado wheat flelds. This gave some control. Because of winds afrplane dusting is not the proper means of application.--Colo. Div. Agr. (28).

\section{Cul1c1dae}

Aedes aepjpt1 (I.), the jellow-ferer mosquito

A dilution of 0.2 p.p.r. chlordane in water lilled 100 percent of the larrae in 48 hours; 0.063 p.p.r. killed 50 percent. DDM was more toxic, 0.05 p.p.m. k1lled 100 percent and 0.014 killed 50 percent.--Ginsburg (125).

Insects confined in a small screen-kire cage were exposed for 10 seconds in a 100-cubic foot sabinet in which chlordane dissolvec in cyclohexanone had been sprayed 20 seconds previously. A 5-cercent concentration of chlordane gave 15 parcent knockdown in 30 minutes and 99 percent mortrl1 ty in 24 hours. The calculated concentration giving 90 percent mortality was: gama benzeno hexachlor 1de 0.4; DDT 1.C: chlordano 3: and toraphene 27. When tested as residues on plywood surfaces at dosafes of 50,100 , 200, and 400 me. per square foot, DDT was the only one of these four compodnds still causing high mortality of mosquitoes at the end of 36 weeks at all dosagos.--Gahrn ot al. (162). 
As a space spray chlordane is slightly more effective than DDT against house flies, but less toxic to yellow-fever mosquitoes. Chlordane, like DDT, is slow in its effect on insects. When compared on the basis of speed of kill, DDT was more rapid against mosquitoes. When evaluated from the standpoint of residual action against house flies, chlordane in dosages of 50 to $100 \mathrm{mg}$. per square foot of surface remained effective for 9 and 24 weeks, respectively, when the flies were exposed for 2 hours. Similar results were obtainod with yellow-fever mosquitoes. In field tests in Florida, when applied by alrplane or with ground equipment, DDT was more effective than chlordane in killing mosquitoeg present at the time of treatment, and also exhibited longer residual effects.--Knipling.--Knipling (264, 265).

A single dose of chlordane was administered orally to rabbits at a dosage of $300 \mathrm{mg}$. per $\mathrm{kg}$. When undiluted chlordane in a gelatin capsule was fed the animal, the mortality of mosquitoes feeding on the rabbit was 4 percent after 1/4 day. When administered as a 10-percent solution in corn oil (5 mg./ kg.) through a stomach tube, the mortality of mosquitoes was 99 percent after 4 days, but the rabbit died.--Knipling et al. (266).

\section{Aedes communis (Deg.)}

A series of labaratory tests with various insecticides were made on fourth-instar mosquito larvae collected in mountain areas in Oregon. Identification of the several lots used showed 93 percent Aedes comminis, 6 percent $\underline{A}$. hexodontug, and 1 percent Aedes sp. The temperature ranged from $50^{\circ}$ to $60^{\circ} \mathrm{F}$. in the various tests. DDT, added as an acetone solution to 1 part in 600 million parts of water, killed about 85 percent of the larvae in 48 hours. DDT and gamma-BHC were about equally toric, and toxaphene, chlordane, and methoxychlor were somewhat less effective.Roth et al. (400).

Aedes sollicitans (Wlk.), the salt-marsh mosquito

Chlordane sprays applied both from airplanes and with ground equipment proved inferior to DDT as a larvicide.-.Fluno et al. (150); Knipling (264).

Chlordane in fuel oil solution, applied by hand equipment in the fall of 1947 in Alaska at 1 pound per acre, gave 66 percent control of Aedes mosquitoes.-Travis et al. (459).

The effectiveness of prehatching treatments for the control of arctic mosquitoes was studied in 1947 and 1948 at Churchill, Manitoba, Canada. These treatments were applied before the spring thaw to snow and ice covering potential breeding areas. DDT, in a wettable powder ( 50 percent) and an emulsion, gave complete control of larrae at 0.1 pound per acre. Chlordane and methoxychlor were slightly and toxaphene considerably less effective than DDT.-MicDufie est al (30?).

\section{Aedes taeniorhynchus (Wied.)}

Same as for A. sollicitans. - Fluno et aㅛ. (150). 
Aedes spp.

Tests were made against Aedes mosquito larrae on 146 one-elght to one-half-acre plots near Anchorage, E'rlutna, and Gulkana, Alaska. Nineteen tests were al so made arainst Cullseta larvae. DDT oil solutions were mors effective than fuel-oil solutions of chlordano. Against Culiseta larvae DDT, in fuel-oil and in water emulsions, was superior to fuel-o1l solutions of chlordane. Five-percent chlordane in fuel-0il at 0.2 pound toricant per acre killed 62 percent of Aedes larrae in 48 hours; the same dosage of DDT silled 98 percent.--vjull in est al. (278).

Studies were conducied at Ft. Churchill, Manitoba, Canada in 1947 and 1948 to compare the effectiveness of new insecticides arainst arctic species of Aedeg mosquito larvae. Chlordane was less toxic in oil solutions thar DDT, Uut Gave comparable kills as emllsions at a dosa acre. None of the materials at the dosrges tested was effective arainst pupae. -ircDuffie et all. (208).

Anopheles crucians Hied.

Same as for A. quadrimaculatus in residue tests in buildings.--Gahan et al

Anopheles quadrimaculatus Say, the comon malaria mosquito

The residual toxicity of chlordane, DDT, and gamna benzene hexachloride was comared by applying emilsified xylene solutiuns of the comounds to the surface of wallboards, which were then exposed at intervals orer a perlod of 16 weeks to adult Anonheles quadrimaculatus. The increase in time required to produce a 100-percent knockdown as the treated surfaces aged was used as an incex of loss in effectiveness of the compound, by volatilization, absorption, or other means. After 16 weeks of agine, the time required for gamm benzene hexachloride treatment to produce a 100 -percent knockdown had increasea by a factor of 10 orer its initial knocledown time. In the same period the time required for the chlordane treatment to produce a 100-percent knockdown had increased by a factor of 3, whereas, that of DDT remained apnroximately constant. It would seen that of the three materials DDT will provide the most permanent toric surface. It is believed that the loss in residual effect from chlordane and gama benzene hoxachloride is due to their greater volatility, the latter being the more volatile of the two. Preliminary volatility mensurements indicate chlordane to be considerably more volatile than DDT. A series of tests made to compare the larricidal properties of cillorane, DDT, and fanme bonzeno hexaciloride to the larvae of Anopheles quadrimaculatus resultad in the conclusion that there was no significant difference in tho three compounds whon applied as acetone suspensions, emulsions, anc dusts.--rierrus ett lㅣ. (245).

At the Orlando, Florida laboratory of the Bureal of Entomology and Plant quarantino it was found that tho toxicity of chlordano was practlcally identical with that of DDT to larva of the malaria mosquito (0.01 p.p.m. k1lled 98.3 percont in each case in 18 hours).--Bishopp (22): Knipline $(\underline{265})$. 
This species was somewhat more susceptible than Aedes aegroti to chlordane spraj residues. Buildings sprayed with 2.5 percent chlordane in kerosene to give a deposit of $200 \mathrm{mg}$. chlordane per square foot remined almost free of mosquitoes for 2 or 3 weaks, whereas in the DDT-treated buildings the number remained very low Ior 15 weeks. -Gahan et al. (162).

Chlordane may be efiectire as a residual poison on wallpaper for three months under certain conditions. The type of surface for residual insecticile apolication is highly important. At the end of 29 weeks DDT was more effective than benzene hexachloride or chlordane applied on a beaver wall board. The toxicity of chlordane on clay was very low after one week. Chlordane, benzene hexachloride, and DDT were much more effective on wall board than on clay. Chlordane spray, $200 \mathrm{mg}$. per square foot, was ineffective a weeis after application on an all-metal shed.--Cutkomp (25).

The various insecticides in order of their residual effectiveness against adult A. quadrimaculatus mosquitoes and house flies over a 26-week period were DDT, benzene hexachloride, chlordane, toxaphene, and TDE (DDD). Chlordane was tested in three combinations: (a) a 5-percent chlordane kerosene emulsion prepared by diluting a 25-percent chlordane, 5-percent Iriton X-100, keroseno concentrate 1:14 with water; (b) a 5-percent chlordane xylene emulsion prepared by diluting a 35-percent chlordane, 4-percent Triton X-100, xylene concentrate 1:6 with water; and (c) a 2.5 percent chlordane xylene emulsion prepared by diluting the 35 percent concentrate 1:13 with water. Application of $200 \mathrm{mg}$. chlordane per square foot was not satisfactory against adult female A. quadrimaculatus at the end of a 16week period. A 100-mg. dosage was not satisfactory at the end of an 8-week period. Application of $200 \mathrm{mg}$. chlordano per square foot against adult house flies was satisfactory for at least 8 weeks, while application of $100 \mathrm{mg}$. was not satisfactory even at the end of 1 week.--Fay et al. (136).

Insectary-reared Anopheles guadrimaculatus mosquitoes were released in rooms which had been sprayed with insecticides at the rate of $200 \mathrm{mg}$. of the active ingredient per square foot. Chlordane, applied as a 5-percent xylene emulsion and as a 5-percent kerosene emulsion, compared favorably with DDT in initial knockdown, but displayed a shorter residual life. It was slightly more effective when sprayed as a kerosene emulsion than as a xylene emulsion.-McCauley et al. (306); Quarterman (380).

\section{Culez pipiens molestus Forsieal}

A strain of this mosquito which was unaffected by contact with 0.2 mg. DDT per square centimeter on glass was sensitive to $1 / 2$ this quantity of chlordane.--Hosna (334).

\section{Culer pipiens var. pallens Coq.}

Mosquito pupae were immersed in aqueous emulsions of toxicants made by diluting a solution of 3 parts toxicant, 15 parts solvent naphtha, and 12 parts sulfonated oil to varying concentrations. It was concluded that chlordane is about 9 times as toxic as $2, D^{\prime}-D D T$ at the $L D-50$; and about 5 times as toxic as $p, p^{\prime}-D D T$ at the ID-99.87.--Nagasawa (342). 
Psorophora c1118ta (T.)

P. confinntg (I. Arr. )

Same as for Aedes sellicltans.-Fluno et el. (150).

Onldentifled mosquitoes

As a larvicide for anopheline and sereral species of cullcine mosquitoes, chlordane generally proved inferior to DDT in both laboratory and field tests.-Kaipling (264).

In labozatory tests chlordane proved highly toxlc to the fourth-1nstar larrae of eleven species of Cal1forn18 mosquitoes.-richelbacher (326).

\section{Blppobosc1dae}

Melophagus or1nus (I.), the sheep-t1ck, sheop ked

Chlordane sprajs have Glven excellent control.--inipling (254).

Papar1a were dipped in 0.5 percent suspensions of 1nsect1c1des and hold at room temperature $\left(67-30^{\circ} \mathrm{F}.\right)$ or at a constant temperature of $80^{\circ}$ F. and a relatire humidity of 50 to 70 percent. Chlordane caused I1ttle if any mortality of pupae. The addition of a wetting agent did not enhance the effect1veness of the materials.-Boffman (221).

Sheep ticks exposed to $24 \mathrm{mg}$. chlordane per square foot at $70^{\circ} \mathrm{I}$. suffered 65 percent mortal1ty and at $90^{\circ} \mathbf{I}$. they sufferea 98 percent mortal1ty. -

A 0.125 percent chlordane emalsion was effective in dipping tests, but less effective when applied as a spray. A 2-percent chlordano dust gave poor control. - P1bbetts and Sorenson (455).

In tests at Corvallis, Oregon ticks collected from sheep were erposed on khak1 wool patches that had been dipped in an acetone solution of the insecticide. After exposing the ticks for 30 minutes at $70^{\circ}$ I., they were transferred to beakers contalning bits of cheesecloth and kept at $70^{\circ}$ to $80^{\circ}$ and an arerage hunidity of about 75 percent. Chlordare was one of the Insect1cides which falled to Eive 100 percont martality in 24 hours on cloth treated at the rate of $25 \mathrm{mg}$. of insecticide per square foot.-Gjullin (126).

Dipping teste showed that 0.2 and 0.5 percent concentrations of chlozdane carsed complete or noarly complete control of sheep ticks durlag the entire 110-day per lod of the test. Wool samples collected from the treated sheop and exposed to housefl1es shoved a high degres of toxicity far chlardano at the 0.05 percent concentration. When Shropshire eves in heary fleece were sprayed with 2.7 quarts of 0.2 percent chlordane, not all the shoep t1cks were kllled.-. Salrchild et al. (135); U. S. Bur. Int. and Plant Quar. (468). 


\section{Hypodermat1dae}

Hypoderma Ineatum (De V1ll.), the comnon cattle grub

H. bov1s (L.), the northern cattle grub

In Ashland County, Oh10,23 insect1c1de formalat1ons were tested on 94 animals for cattle grub control. A mlxture of 5 percent chlordane and 95 percent linseed o1l gave 54.5 percent mortality; a mirture of 5 percent chlordane, 5 percent water, and 90 percent lanolin gave 91.9 percent mortality.-Telford (453).

Emrlsions and wettable powder spreys containing up to 1.5 percent chlordane, applied as a wash and with a high power sprayer, caused less than 20 percent mortality of the cattle grub larvae. Dusts containing up to 5 percent chlordane al so proved ineffective.--U. S. Bur. Ent. and Plant Quar. (468); B1shopp and Knipling (24).

A spray containing 4 pounds of 50-percent wettable chlordane per 100 gallons of water and a spray containing 1 gallon of 15-percent emal siflable chlordane concentrate per 100 gallons of water, were ineffective. The sprays were applied at 350 to 400 pounds pressure.-Furman and Douglass (161).

Preliminarg laboratory work indicated that a 1.5 percent suspension of chlordane prevents the eggs from hatching. A spray contalning 2 percent chlordane (as a wettable powder), applied 4 times at 2-week intervals to cattle, resulted in an average of 12.2 grubs per anlmal being removed as compared to 39.9 In the untreated check. The insecticides were appl led with a power sprayer at a pressure of 300 pounds per square inch. Special care was taken to see that the entire surface of each cow's body was wet to the sizin and an average of 5 gallons of spray material per animal was used. Three of ten cows sprayed with chlordane died after the fourth application and this treatment was discontinued.--Graham (192).

\section{Muscidae}

Hrlemra antiqua (Me1g.), the onion maggot

The common onion maggot, and the blacis onlon fly, Trltoxa flexa Heldemann, were controlled successfully during 1948 in Minnesota by chlordane in large fleld plots of commercial onfons and in the laboratory.-Granorsky (194).

Hylemya brassicae (Bouche), the cabbage maggot

At Corvall1s, Oregon in 1947 a 5-percent chlordane talc dust applied to the soll at the rate of 27.5 pounds chlordane per acre was inefiective in preventing maggot injury to radishes, kohlrab1, broccol1, mustard, and rutabaga.-Crowell et al. (21). 
Chlordano gare the best results arainst cabbrge maggot in radishes of all materials tewted. A dust containing 0.4 percent of chlordane permitted only 1.8 percent infestation, whereas untreated plants had an infestation of 52.4 percent. A spray containing 0.1 percent of chlordane pernitted 4 percent average infestation, a better result than vas obtained with BEC, toxaphene, mercuric chloride, and DDT.-Dills and Odland (104, 206).

At Puyallup, Washington, a 5-percent chlordane dust permitted 26.4 and 26.2 percent maggot infestation in broccoli two and four months after transplanting. - Stitt and Elde (440).

Hrlemve c1licrure (Rond.), the seed-corn maggot

Seed treatment gives little promise as a control measure for the seed ccrn maggot. A 5-percent chlordane dust used as a soll treatment reduced maggot infury, but imparted a slight flavor to dried beans.-Aistich and Schwardt (294).

Chlordane at 5 pounds per acre mired with 4-12-4 fertilizer was highly effective.-Floyd and Smith (142, 149).

Musca domestice I., the house fly

Although chlordane is somewhat more effective than DDT to house flies on the basis of inftial killine action, it lacks the lasting effects of DDI. In laboratory tests surface treatments at the rete of $200 \mathrm{mg}$. per souarc foot gave complete or near complete kill of flles exposed for two bours as long ag 28 weeks after treatment. DDT, however, was still completely effective after 36 weeks even at the low rate of 50 me. per square foot.-B1 shopp (33): B1shopp and Knlpling (34); U. S. Bur. Int. and Plant Quer. $(468)$.

The relative toxicity of chlorcane and DDI to the acult house fly was measured by the "large group" Peet-Grady procedure. Under the conditions of the tests it was found that 0.2 -percent DDT or 0.05 -percent solut1ons of chlordane are required to produce a 95 percent mortality in 24 hours. A median lethal concentration was estimated from probit-log dosage curves which indicated that a 0.06 -percent solution of DDT or a 0.02 -percent solution of chlordane would be required.--Kearns et al. (245).

Chlordane acts as a fumigant 8 s shown by tests in which house flies were exposed to vapors from residual deposits.--Hoffman and Lindquist (222).

Chlordane was mixed with food and fed to larrae of Musca domestica, Tribelium confusum, Enhest1a kuehniella, and the caults of sitoph1lus exanariug. The results obtained with chlordane and with enma benzene hexachloride are very similar, both compounds showing nedian lethal concentrations of less than 50 parts per million to all four species.--Erown et al. (52).

The toxicity to house flies of surface coating containing chlordane was determined by painting the inside of a small bor with mixtures of 20 
percent of chlordane and 80 percent of urea-formaldehyde, nitrocellulose, or polymerized diolefins dissolved in a vehicle. The time for knockdown of flies placed in the box was greater for chlordane than for DDT in all three coatings.--Block (26, 32).

Flies confined in a small screen-wire cage were exposed for 2-minutes In a 100-cubic foot cabinet in which chlordane dissolved in cycloheranono had been sprayed 30 seconds previously. A 5-percent concentration of chlordane gare 8 percent knockdown in 30 minutes and 100 percent mortality in 24 hours. The calculated concentretions giving 90 percent mortality were: gamma benzene hexachloride 0.17; DDI 1.0; chlordane 0.88; and toxaphene 4.9. In residue tests ( $10 \mathrm{mg} / \mathrm{sq} . \mathrm{ft.}_{\text {.) }}$ chlordane was superior to DDT in kill of flies after 8 weeks.-Gahan et al. (162).

A mixture of 0.8 percent of $\operatorname{Van}$ Dyk 264 [\$-(2-ethylhexyl)bicyclo(2.2.1)-5-keptene-2,3-dicarboximide], 0.2 percent of pyrethrins, and 0.2 percent of chlorcane in Peet-Grady tests gave a 10-minute knockdom of 99 percent and a 24 -hour kill of 98 percent. It requires a concentration of 2 percent of $\operatorname{Van} D y k 264$ plus 0.025 percent pyrethrins to give satisfactory k1Il and knockdown of house flies. When 0.2 percent of DDT or chlordane was added, the concentration of the compound could be reduced to $I$ percent and a satisfactory kill and knockdorm obtained.--Hartzell (207).

Toxicity of insecticides expressed in terms of percent mortality or ID-50 may vary greatly in different laboratories and at different seasons of the year, eren if the same equipment was used. Toxicity index, which is used as a relative value to express the toxicity of insecticides, is defined as the ratio between the $\mathrm{LD}-50$ of a standard insecticide and the ID50 of the test sample, multipled by 100. The toxicity of technical chlordane to house flies, determined by the tunnel spray method of Roan and Kearns, varied from 154 to 190 (alpha chlordane = 100). The toxicity index of alpha chlordane (a stereolsomer of chlordane, m.p. 101-102.5० C.) wa.s 6.5 (diel$\operatorname{drin}=100)$ or 12.1 (aldrin $=100)$. Sun (447)

The effect of temperature on speed of knockdown and mortality of house flies exposed to residues of several chlorinated hydrocarbons was determined by exposing house flies (I) continuously at constant temperatures of $70^{\circ}$ and $90^{\circ}$ F. and (2) for predetermined periods ( $I$ to 20 minutes) at $70^{\circ}$ and $90^{\circ}$ and then holding thom for 24 hours at the same temperature at which they were exposed. At a dosage of $50 \mathrm{mg}$. per scuare foot chlordane required 100 minutes for knockdown at $70^{\circ} \mathrm{F}$. and 63 minutes at $90^{\circ} \mathrm{F}$. Hoffman and Indquist (223).

A deposit of $144 \mathrm{mg}$. chlordane per square foot of plywood panel k1lled 100 percent of NAIDM house flies exposed for 5 minutes.--Hansens and Goddin (203).

In 1948 in California a comparison of the chlorinated insecticide for fly control in dairy barns showed BHC to be the most satisfactory material for the replacement of DDT. Only the barn walls were sprayed - not the animals. Chlordane at 50 pounds per 100 gallons of water was slow in knockdown, gave an excellent clean-ip, and lasted for from 1 to 4 weeks. - Dietz (103). 
Insect1cldes were applied on varlous surfaces anc exposed to d1sferent environmental conditions in several experiments to determine the Ir residual toxicities to the house fly. DDT and gamma-BEC vere 1 attlally tho most toxic compounds. The other three materials were, in order of thelr dimln1sh1ng toxic1ty, chlordane, Rothane D-3, and toxaphene. BEC gave the most rapld knockdown, followed by DDT, Rhothane D-3, chlardane, and toxaphene. Vapors from sama-BEC were about three t1mes as toxic to flles as tbose from chlordane; both were extremely toxlc as fumlgants. Tho order of persistence of the residual treatments was, from the most to the least, DDI, Fhothane D-3, toxaphene, chlordane, and BEC.--Bruce (54).

Cristol (88) In 1949 exan1ned the bypothosis that the 1nsect1c1dal activity of various polychloro 1nsect1c1des is due in large measure to the ab1l1ty of the compound to l1berate hydrogen chlarlde at tho site of act1on of the insecticide. The relative toxicities to the house fly of the varlous constituents of technical chlordane were as foll ow 8 :

Relat1ve effect1re dosages (Technical chlordane $=0.01$ )

Heptachl or
Octachlor, act1ve 1scmer
Octachlor, Inact1ve 1somer
Nonachlor

.0043

.0056

.017

.020

In reactions with $0.04 \mathrm{M}$ ethanol1c sodium hydroxide at $46^{\circ} \mathrm{C}$. the insect1cidally actire octachloro 1somer and the nonachloro compound reacted much more rapidly than the heptachloro compound which is the most effective Insecticidally, showing that dehydrochlorination w1th alkal1 and 1nsect1c1dal actirity have no systeratic relat1onship.

Geradorff et al. (123) determined the relative toxic1ties of certain chlor Inated hydrocarbons to the house fly when applied as space spray 8 using the Campell turntable method. Crystalline chlordane was about twothirds as toxic as technlcal chlordane. which proved to be one-fourth 8 s torlc as aldr1n and heptachlor. None of the sprays made with the chlorinated compounds caused appreclable knockdown.

Organ1c insect1cides in various concontrations and formulations were used to treat 154 da1ry barns in New York in 1949. Chlordane emuls1on, 6 , 12, and 24 pounds of toxicant per 100 gallons of water, prorlded 4 weeks or more control of house flles in those barns which were heavily infested before treatment. A mixture of chlordene (6 1bs.) and DDT (3 1bs.) was more effective than elther chlordane or DDT alone.-P1mental et al. (36?).

Same as for S1phona 1rritang.-Bruce and Decker (56).

Sare as for Anopheles quadr1maculatus. - Fay et al (136).

\section{Res1stant house 11108}

Houre fl10s that had developed a resistance to DDT were tested agrinst other insect1c1des. The special stock was distinctly rore resistnnt to all 
the materials tested than the regular colony. Although a few reversals occurred in the individual tests, none appeared in the final averages at any concentration. Po obtain equal mortalities, approxinately twice as much toxicant was required for the special stock as for the regular stock with DDT, chlordane, pyrethrum, and rotenone. These tests show that the method of selection resulted in the development of an unusually strong stock of flies rather than one having a specific resistance to DDT.--Hilson and Gakan (498).

In tests made in southern California in 1949 against resistant houseflies chlordane, applied as a 40-percent wettable powder at 50 pounds per 100 gallons of spray (approximately 2.5 percent), gave an excellent initial clean-up and in some cases residual action lasted up to one month. In other cases, however, reinfestation was very severe after one to two weeks. The rate of fly knockdown by chlordane is slower than that of DDT.--March and Metcalf (313).

In samples of flles obtained from seren localities in five states heary deposits of wettable chlordane and methoxpchlor were nonrepellent or even slightly attractive. Respraying of two barns with chlordane emulsions and two with suspensions of methoxjchlor provided a high degree of control for several weeks.--King and Gahan (263).

Flies from 6 barns in New Jersey which had been sprayed with DDT exhibited resistance in laboratory tests to technical DDT and $p, p^{\prime}-D D T$ residues of $144 \mathrm{mg} . /$ square foot. All these resistant flles were killed in tests using residues of chlordane.-Fansens et al. (204).

Specimens of a wild population of hovse flies that had survived repeated residual-type applicaions of DDT in Hlenville, New York were captured and offspring were cultured in the laboratory through three generations. Tests vere mede to determine whother this line of flies was resistant to DDT and other new insocticides as compared with a laboratory line of flies whose ancestors had never been exposed to these insecticides. The results of these tests showed that flles of the mlenville line were highly resistant to DDT and related compounds, but showed no resistance to certain unrelated chemicals. The results of the tests with technical chlordane are as follow: A total of 18 tests were made in whlch flles were exposed for 2 hours, 1 hour, 30 minutes, or 15 minutes to surfaces to wh1ch 144, 100 , 70 , or $14.4 \mathrm{mg}$. of the active materlal had been applied per square foot of surface. All flies exposed to surfaces to which the three larger concentrations had been applied were killed as were those exposed for 1 hour to a surface to which $14.4 \mathrm{mg} \cdot /$ square foot had been applied. The percentages of mortality of flies of the laboratory and Ellenville lines exposed to the latter surface for 30 minutes were 100 and 94.4, respectively, and for 15xinutes exposures they were 95.6 and 60 , respectively. The comparative rates of mortality for all tests in which 387 flles of the laboratory Iine and 459 of the Ellenville Iine were used, were 99.7 percent for laboratory flies and 98.5 percent for Ellenville flles.--Barber and Schmitt (26).

In another series of tests with technical chlordane agalnst these same 2 lines of flies, five tests were made in which flies were exposed 
for 2, 5, 10, or 15 minates to a surface to which 144 mo. of the active ingredient had been applied per square foot. Of the flles exposed for 2 minutes 97.6 percent of the laboratory 11 ae and 94.9 percent of tbe Ellenville line were killed. All fles of each line were killed whon exposed for the longer periods to th1s residue. Of 210 flies of the laboratory Iine exposed to this residue an arerace of 99.5 percent were killed, and of 208 flies of the Ellentille line simllarly exposed 99.0 percent were killed. Five tests were made in which flies were exposed for 15, 30 , or 45 minutes or for 1 or 2 hours to a surface to which $14.4 \mathrm{me}$. of the active 1 aredient had been applied per square foot. Of a total of 172 flles of the labaratory line exposed to these surfaces an average of 66.9 percent were killed and an average of 71.1 percent of 152 flies of the Dilenville Iine were killed by olm1lar exposures.-Barber and Schritt (2).

In Italy Bettini and Barachin1 (20, 32) reported that flies resistant to high doses of DDT $(5.3 \mathrm{~g} . / \mathrm{sq}$. m. $)$ all died when they came in contact with chlordane and BEC.

The susceptibility or resistance of the various stralns of flles studied was determined from data obtsined by toplcal applications of the toricant to the thorax of female house flies. Acetone solutions of the insecticides were used in all tests. The dosage-mortality data vere used to calculate the ID-50 ralues in terms of mlcrograms of toxieant per gram weight of 117 . The data indicate that the acquisition of tolerance for one insecticide contributes to tolerance for the others. The ID-50 of chlordane to the NAIDM straln of 11108 vas 8.2 (DDT $=16.8$ ); whereas to the flles that had become resistant to DDT $(I D-50=18,728)$, the $I D-50$ of clalordane was $15.5 \mathrm{mlcro-}$ grams per gram wolght of fly.--Dzuce (55).

Two strains of Illes (one laboratory reared, the other collected in the field) were exposed to residues of seven insecticides. The materials tested, in order of decreasing effectiveness to the non-resistant flies, were dieldrin, gamma isomer of benzene hexachloride, aldrin, DDT, chlordano, methoxychlor, and emulsiflable pyrenone. The fleld collected flles were 7 times more resistant than the laboratory reared flies to DDI. There was no detectable difference in the reaction of the two strains to dieldrin, gamma-BHC, aldrin, chlordane, and emalsifiable pyrenone.--P1aentel and Dewey (26́6).

In Denmark DDT-resistant and control flies reacted unfformy toward chlordane.--Keiding and Van Deurs (24?).

In Itrly flies resistant to DDT were somewhat more resistant to chlordane than were non-DDT-resistant flles.-nlessandro and Smiraglia (12).

Experinents with chlordano and other insecticides arainst DDT-=esistant flies are crit1cally discussed by Patrissi et rl. (359).

S1phona 1 rritang (I.), tho harn fly

In laboratory knockdown tests agalnst the hornfly small screen-uire cagos were dipped in preparations containing 0.5 percent of different 
chlorinated hydrocarbon insecticides. The methorychl or caused complete knockdown in 5 minutes, DDT in 8, WD in 17 , chlordane in 53, and toxaphene in 73 minutes in tests made 24 hours after the cages had been dipped. After 2 months' exposure the methoxychlar, DDT, TDE, toxaphene, and chlordane caused complete knockdown of flles in 12, 62, 152, 248, and 360 to 720 minutes, respectively. The cage treated with methoxychlor apparently lost little of 1ts effectiveness. The knockdown of flies exposed to animals treated with the insecticides was the same as that determined in the laboratory, except that a longer time was required.-Eddy and Graham (I22).

Chlordane has been tested on animals exposed to horn flies in cages, and in fleld tests on dairy animals in Texas and beef animals in Kansas. Nettable powder sprays at concentrations of 0.25 and 0.5 percent chlordane (applying an average of approximately 2 quarts per mature animal) have given good control of horn flies. The two concentrations protected animals for about 3 and 4 weeks, respectively. Chlordane was slightly inferior to DDT for tho control of horn flies.-Bishopp and Knipling (34); Cuff (22); Laake (280); Smith (42I); U. S. Bur. Fint. and Plant Quar. (468).

In IIIno1s chlordane emulsion was as effective as DDT and TDI (DDD) emulsions in controlling these flies on milk covs.-Bruce and Decker (56).

Stomoxrs celcitrans (I.), the stable fly

The speed of knockdown and kill and the duration of effectiveness of II of the more recently developed organic insecticides were studied in laboratory tests against the stable fly. Tho 14-mesh copper-wire cages were dipped in a 1 percent solution of each test material in acetone. One cage was held indoors while its duplicate was stored outdoors, fully exposed to the effects of the weather. In the tests made 24 hours after the cages were treated, DDT and methoxychlor proved to be the fastest acting compounds and toxaphene and chlordane the slowest acting. From the standpoint of knockdown and duration of effectiveness, methoxychlor and the bromine analog of DDT appeared to be superior to any of nine other compounds tested, including DDT. Parathion, aldrin, and toxaphene appeared to retain their toxic properties longer than did TDE, gamma-BHC (95\%), compound 153, heptachlor, or chlordane.-- idddy and McGregor (128).

Chlordane, as a 2-percent water suspension made from a 50-percent wettable powder, proved equal to DDT in the control of house flies and stable flies.-.huma and Hixson (335).

Same as for Siphona irritans.--Bruce and Decker (56).

Psychodidae

Psychoda alternata Say, the filter fly

In June 1949 f1lter flies, whlch had become tolerant to DDr, proved susceptible to chlordane. However, the third and fourth chlordane treatments were considered fallures. Th1s served again to 1llustrate the rapld acquisition of insecticide tolerance by insects through the treatment of tho larral habitat, the filter bed.-- Bruce (55). 


\section{Sarcophag1dee}

Mang specles of fl1es, including Sarcophagidae, wero killed by chlordano $3 / 4$ ar 1 pound per acre, applied for the control of Easshoppers.-Severin (413).

\section{S1:milidae}

\section{Simulium latioes Fries}

\section{S. Tenustum Say}

S. I1ttatum Zett.

In tests in Alaska a chlordane-acetone, suspension was not effect1ve agalnst larvae at 0.5 p.p.m.-Gjullin et al. (127).

In Alaska chlordane proved inferior to DDT, TDE, and thoxychlor for the control of black fly larvae.--Traris (458).

Chlordane was tested in the form of a 25-percent exulsion concentrate w1th 65 percent syleno and 10 percent Triton $X-100$, also as a 10-percent solution in Velsicol AR-50 and fuel o1l. Chlardane in fuel o1l, at 1.185 p.p.J./min., or 1:12,700,000 for 15 minutes, gave partlal control for a short distance from the point of application.-Hocing et al. (220).

In flume tests on larvae of a black fly, S1mulium renustum Say, made in the sumper of 1947 in the Mite Mounta1ns of Now Lampshire, chlordano d1d not cause 100 percent detachment at 4 p.p.m.--Kindler and Regan (26l).

\section{Taban1dao}

\section{Tabamus sulc1frons Macq.}

Chlardane is ineffective in protecting animals from attacis by horse fl1es.-B1shopp and KnIpling (34); Knipling (264).

Chlordane as a 10-percent solution in a mixture of Numbor I fuel o1l and cyclohexanone was applied at the rate of 2 pounds of toxicant per acre by a plane whlch flew at 5 to 20 feet above the tree canopy. The effect1reness of the materlal was determinod by counting flles attacking draft horses led through the test plots 1 day before spraving and 1, 2, 3, 5, and 7 days after treatment. The results appeared somewhat erratic and no appreciable effect on fly populations could be demonstrated for any of the insoct1cides tried. Tabanus abactor and $\underline{T}$. sulcifrons were the two most abundant spec1es. T. atratus, T. Jitt1ger, T. mularis, and I. venustus were present in small numbers. A few specles of Chrysops and S1lviug were al80 present.--Howell et 제. (228).

Chlordane contimes to kill tabanids feedlag on livestock for about one day after treatment.-U. S. Bur. Ent. nad Plant Quar. (468). 


\section{Trypetidae}

Dacus tryonl Frogg., a fruit fly

In Now South Wales, chlordane proved inferior to DDT, benzene bexachloride, and tartar emetic far the control of this fruit fly on plum. The chlorinated insecticides were applied as diluted emulsions containing 0.2 percent of the toxicant at fortnightly intervals at the rate of about 1 gallon per treo. Sugar at the rate of 1 pound per 10 gallons of spray was included with all three chlorinated insecticides to encourage feeding by the flies. The balt spray consisted of 2 ounces tartar emetic and 2.5 pounds of sugar in 4 gallons of water, applied at the rate of nearly 9 fluid ounces per tree. At barvest the percentages of undanaged fruits were 93.8 for tartar emetic, 92.3 and 85.9 for the two DDT sprays, 69.7 for benzene hexachloride, and 56.1 for chlordane. Allman and Friend (14).

Ihagolet1s cingulata (Loow), the cherry fruit fly

R. fausta $\left(0 . S_{.}\right)$, tho black chorry fruit fly

Chlordane, 50-percent wettable powder at 1 pound of toxicant per 100 gallons of water, greatly reduced the infestation, but failed to me日t the requirenent of 99.5 percent of maggot-free fruit.--Cox (86).

Rhagoletis pomonella ( $\mathrm{Falsh}$ ), the apple maggot

In laboratory tests at the New York Agricultural Experiment Station in 1947 chlordane showed a high degree of toxicity. The rate of kill at the higher dosage levels was more rapid than with DDT, although the knockdown rate was slower.-Dean (29).

\section{SIPEONAPTERA}

Pulic1dao

\section{Ctenocephal1des spp.}

When dogs were dipped in a 0.42-percent technical chlordane emulsion all fleas were dead in 1 hour. No fleas were found at the end of 24 hours on cats similarly dipped. Redipping these cats $?$ and 23 days later caused no bad effect.--Turk and Batte $(\underline{460})$.

\section{ACARINA}

\section{Ixodidae}

Amblyomma emer icamum (I.), the lone star tick

Chlordane dips at concentrations of $0.25,0.5,0.75$, and 1.5 percent gave complete or nearly complete control of the flat stages on goats and 
cattlo and 0.75 and 1.5 percent concentrations caused nearls complete k111 of all stages. DDT on the same basl falled to kill all of tho engorged forms at 1.5 percent concentration. The tvo insecticides were about equal in preventing reinfestation.--U. S. Bur. Ent. and Plant Quar. (468).

In prel1minary tests at Camp Bul118, Teras, against the lono star tick dusts, applied at the rate of 1 to 2 pounds of chlordane per acre, were superior to DDT dusts applied at the same rate. A wettable powder and an emilgion containing chlordane when applied as sprays to infested cattle at concentration ranfing from 0.25 to 1.5 percent chlordane also proved more effective than DDM againgt the same tick. The two waterials, hoverer, apDeared to be about equal on the basis of duration of effectiveness against reinfestation.-Bnipling (264).

In tests in Florida chlordano proved promising afalnst the lone star t1ck when applied as a dust to infested areas, and it appeared to be superfor to DDT for this purpose.--Knipling (265).

Dipping dogs in a 0.42 percent technical chlordane emulston killed all ticks except a fow engorged females.--Turk and Batte (460).

\section{Boonh1lus microplus (Canestr.)}

Four cows were sprayed with a 0.25 percent emulston of chlardane everg 28 dajs. No female adult ticks reachod maturitp on these covis although they were exposed to heapy larval infestation.--Legg (286).

\section{Dermacentor albiplctis (Pack.), the winter tick}

Chlordano shows a distluct superforlty ore: DDT agalust the winter tick on cattle and horses. Nearly complete control of all stases has been obtained with sprays at concentrations of 0.75 percent chlordane, whereas DDT at 1.5 percent killed only a small percentage of the engorged forms. Frow the standpoint of protect1on against relafestation chlordane is also superlor to DDM. At 0.5 and 0.75 percent chlordane prevents reinfestations for about two nonths as compared with one nonth for DDT at the same conentrat1ons. Chlordane as a 5-percent dust has also glver gooc ccntrol o? winter ticks and provod superior to DDT.-Bikhopp and Enipline (34); U. S. Sur. Ent. and Plant Quar. (468).

\section{Dernacertor $\operatorname{var1ab111s~(Say),~tho~American~dog~tick~}$}

Sace as for Amblyomma amer1canum.-U. S. Bur. Int. and Plant Guar. ("68). Dermanisgug gallinae $\left(D_{e g}\right)$, the chicien mite

Dusts contafning 2 percent and 5 percent cf chloriane were dusted Into a petr1 dish, mites were placed on the dusted surface, and the cish was covered to prevent the1r escape. There were no dead mites in the chlcriane tests at the end of 48 hours.--51xson fad Num (210). 
Otobius megnini (Duges), the ear tick

A mixture of 5 parts of chlordane and 95 parts of pine oil introduced into the ears of cattle remained effective for 22 days and was cansidered at least as effective as a mixture containing 5 percent of $B H C$ in repelling larvae of this tick.--U. S. Bor. Animal Ind. (465).

\section{Psoroptidae}

Psoroptes equi var. cuniculi (Delafond), the ear mite

These mites on a rabbit were not killed when the rabbit was fed chlordane.--Knipling et 2 l. (266).

\section{Demodicidae}

Demodex canis Leydig, the dog follicle mite

\section{Sarcoptidae}

Sarcoptes scabiel canis (Gerl.), mange or sarcoptic mite of dogg

Five dogs heavily infested with sarcoptic mange, of which 3 had lesions of demodectic mange, were treated with an emulsion of 0.25 percent chlordane. All treatments were applied by dipping the animals and holding them in the liquid for from thirty to sixty seconds with at least two complet submergences. The dip was warmed to a temperature of 100 to $110^{\circ} \mathrm{F}$. Exceptionally large or heavy demodectic lesions were scrubbed with a firm-bristlod brush while the animal was in the liquid. The dogs treated with chlordane were allowed to run with untreated animals. One of the chlordane-treated dogs that was heavily infested with sarcoptic and demodectic mange also had several small demodectic lesions three weeks following treatment. As isolation of the test animals was not complete, no further checks on the test wore made. Wone of the animals showed any ill effects from the treatments.--linuma and Spencer (336).

Chlordane was effective in treating common and red mange in dogs. The dogs were dipped in a 50-gallon barrel half filled with a 0.25 percent chlordane solution, and held in the dip for 30 to 60 seconds.--Spencer (433, 435).

\section{Sarcoptes scabiei suis (Gerl.)}

One application of a 0.25 -percent chlordane solution thoroughly applied comoletely cleaned up sarcoptic swine mange on 800 infested hogs in Hebraska. The 0.25 -percent chlordane solution was made by adding $500 \mathrm{ml}$. of 74-percent emulsifiable concentrate to 50 gallons of water. This was applied with a power sprayer using from 1 to 2 quarts per head with from 50 to 250 pounds of pressure.-Dpencer $(433-435)$. 


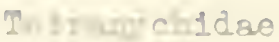

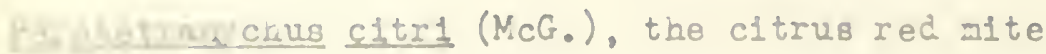

In laboratory tests the 24 hour median lethal concentration of chlor3we to tho mite was 1.0 percent.-fietcall (224).

Petranychus bimaculatus Harvey, tho two-epotted splder mite

Dusts containing 2 or 3 percent of chlordane were less effective thar ducts containing 5 percent of azo'cenzene or 0.5 percent of parathion in controlling the two-spotted mite on lima beans, also chlordane sprejs of 1 or 2 gounds of 20-cercent wettaile powder per 100 gallons of water vere less effective than sprays of toxaphene, benzene hexachloride, Ezobenzeno, anc teracthyl tetraphosphate.-- Iruckett (220).

A spray of chlordane 50-percent wettable powder (0.125 percent chlordane) was applied to soybean plants which were then infested with ultes. After 19 days the mumer of I 1 ve mites on the bean follage was about the ura as in the test where 0.125 percent DDT was applied. The parathion trued soybeans showed the lowest populations of mites and egEs at the end Wh the tests.--Wingo and Thomas (502).

Tetranchus pac1ficus McG., the Pacific mite

Chlordane at 0.5 pound of 50-percent emils 10 for 100 Eallons of ater controlled Pacific mites well unt1l the end of June, but after that, although the trees were sprayed seven times altogether, control was poor. Those tests were made at Yak1ma, Washington in 1947.-liewcomer and Dean (346).

\section{letranychus spp.}

Red spider 1nfestations on cotton developed in some cases where a dust containing 3 percent of chlordane and 3 percent of DDP was used.

Against tho red splder 10-percent chlordane was more effective than sultur. - Bishopp (32).

The red spider on cotton is not controlled by chlordane. - Herned (205).

In the state of Washington in 1947 chlordane proved relatively ineffecive pealnst mites, but controlled the woolly aphld to some extent. It dces not seem to bave a place in the orchard spray program.-liewcomer (345).

Trombiculidae

\section{Aomb1017 a (Eutromb1cula) gplendens Ew1ar}

1. (Eutromb1culn) alfreddugos1 (Oud.), the chigear

Applied as an emulsion, chlordane at 8, 4, and 2 pounda per acre erve 
control equal to that of hydroxypentamethylflavan at 4 pounds per acre throughout the 17-day period of observation.-Simith and Gouck (422).

Applied as a dust or spray at the rate of 2 or 4 pounds per acre, chlordane compared favorably with other miticldes, such as benzene hexachlorlde and hydroxypentamethylflavan.--Knipling (264); U. S. Bur. Ent. and Plant Quar. (468).

\section{Trombidildae}

Elutrombidium trigamum (Herm.), the red grasshopper mite

Very few grasshopper mites were killed by chlordane, 3/4 or 1 pound per acre, applied for the control of grashopper.- Severin (413). 


\section{LITHEATUPE CITED}

(1) Anopreous

1948. Compat1b1l1ty chart for 1nsect1cides and funfic1des. Arer. Tru1t Grover 68(2): $40-41$.

(2)

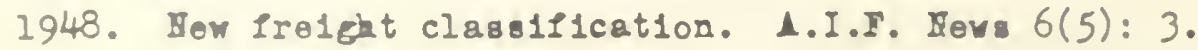

(3)

1948. Synerg18t for pgrethr1n. Chem. and Ing1n. Tows 26: 338.

(4)

1949. Weather factors in spray 1n and dusting pome frults. Amer. Iruit Grover 69(2): 24-25.

(5)

1949. Corpat1b1l1ty chart for 1nsect1c1des and fung1c1des. Amer. Fruit Grower 69(2): 36-37.

(6)

1949. Weatber 1actors in spray 1ne and dust1n stone frults. Arer. Truit Grower 69(3): 21.

(7) Sdams, J. A.

1949. The Oriental beetle as a turf pest assoclated vith tho Japanose beetle in Iow York. Jour. Econ. Int. 42: 366371.

(8)

1949. Crclecephala boreal1s as a turf post assoclated with the Japanese beetlo in Siew York. Jour. Econ. Fot. 42: 626628.

(9) -.... and Matthys8e, J. G.

1949. The Japarese beetle. I. I. Ag. Col. (Cornell) Rt. Bul. $770,14 \mathrm{pp}$.

(10) Alessandirla1, M. R.

1949. Detect1on and dotermination of Octaklor (chlorcano) and DDI on surfaces sprayed with these tro products elther separately or mixed together. (In Ital1an). Ist. Super. d1 San1t. Rend. 12: 338-347. Also 1n A=0. d1 Ch1m. Appl. [Rome] 39: 298-303.

(II) -... and Amormino, $\nabla$.

1949. Character1st1cs, detect10n, and determinat1on of Octaklor (chlordane). (In Ital1an). Ist. Super. d1 San1t. Read. 12: 348-357. Also in Ann. d1 Ch1n. Appl. [Ro: 39: 199-207. 
(12) Alessandro, G. D'., and Smiraglia, C.

1949. Beharior of streins of Musca domestica sensitive and registant to DDT, with respect to benzene hexachloride and chlordane. (In Ital1an). Soc. Ital. d1 B1ol. Sper. Bar. 25: 305-307.

(13) Allen, E. W.

1949. A Japanese weev1l appears in damaging numbers. Jour. Econ. Int. 42: 540 .

(14) Allman, S. I., and Iriend, A. H.

1948. Now insecticldes and frult fly control. Aer. Gaz. I. S. Wales 59: 531-533.

(15) -... and Wright, J. A.

1948. Grasahopper control. Becent developments. Agr. Gaz. H. S Wales 59: 233-236, 283-288, 345-349.

(16) Ameriean Medicel Association

1948. Pesticides: Chomical contaminants of foods. Iner. Mod. Assoc. Jovr. 137: 1604-1605.

(17) American Medical Association Counc1l on Foods and Nutrition

1948. Health hazard of pest1cides. Amer. Med. Assoc. Jour. 137: 1603.

(18) Anderson, I. D., and Hasho, J. $Y$.

1949. Control of corn earworn on sweet corn in southern

Cal1fornia. Jour. Econ. Tht. 42: 933-941.

(19) - - and Hofmaster, R. N.

1948. Pea aphid control experiments in V1rginia in 1947. Jour. reon. Int. 41: 278-282.

(20) Arant, I. S.

1947. Besults obtalned from use of varlous insecticides in cotton insect control at Alabama Frperiment Stations. Sowtheastern Cotton Insect Control Conference Proc., Columb1a, S. C., Dec. 8-9, 1947. pp. 23-25.

(21)

1948. Prellalnary fleld tests with nou insecticides for control of velretbean caterpillar. Jour. Econ. Fint. 41: 803.

(22) Ard, J.S.

1948. Detection of chlordan (octachloro-4,7-methanotetrabydroindane) in insecticlde oll prays. Analgt. Chom. 20: $858-859$.

(23) Arizona Agricultural Experiment Station

1948. Third Annual Report, Bconomic Polsons. Sp. Bul., $45 \mathrm{pp}$. 
(24) Armand, J.I.

1948. Control of virovoras in southwestern Ontario (Prolininary report). Bnt. Soc. Ontar10 1nn. Rpt. (1947) 78: 15-24.

(25) Armitare, H. M.

1947. State of California Departaent of Agriculture, Burear of Rantomolog and Plant Quarantine, 28th 1nn. Bpt. 36(4): $141-201$.

(25) Barber, G.W., and Schm1tt, J. B.

1948. House flies resistant to DDT residual spray. N. J. Agr. Ixpt. Sta. Bul. 742. 8 pp.

(27) -... and Schmitt, J. B.

1949. Turtber studies on resistance to DDI in the borsefly. Jour. Fon. Hint. 42: 287-292.

(28) Batte, E. G., and Gaines, J. C.

1948. Comparison of DDT and chlordane for the control of the horse lorse. Jour. Icon. Ent. 41: 830-831.

(29) -... and Turk, R. D.

1948. Toxicity of some syathetic insecticides to dogs. (Sc1. note.) Jour. Econ. Ent. 41: 102-103.

(30) Bottini, S., and Barachini, B.

1948. First results in the control of bouseflios resistant to DDI with chlordano and benzene bexachloride. (In Italian.) Riv. di Parassitol. 9: 85-91.

(31) -...- and Barachin1, B.

1342. First results of the control vith chlordano and benzone hexachloride of house Nies resistant to DDT. (In Italian) Ist. Super d1 Santt. Read. 11: 841-348.

(32) Bishopp, I. 0 .

1946. Now insecticidos. Agr. Chem. I(6): 19-22, 39-40.

(33)

1948. Large scale insoct control problozs. Soap and Sanit. thom. 24(2): 143-145, 169 .

(34) - - - and KnIpling, I. r.

1948. Insectic1des appl1ed on 118estock. Indus. and Infin. Sisus. 40: 713-716.

(35) Blanchard, R. A., and Chamberlin, T. B.

1943. Tests of 1nsect1c1des, including DDT, agringt the cora earworm and the fall argworm in corn. Jour. Econ. Int. 41: 928-935.

(36) Block, S. S.

1948. Insect1cidal suriace coat1ngs. Soap and San1t. Cher. $24(2): 138-141,171$ : and $(3): 151-153$. 
(37) Block, S. S.

1948. Besidual toxicity tests on insecticidal protective coatings. Soap and Sanit. Chem. 24(4): 155, 157, 159, $161,207,213$.

(38) Bobb, M. I.

1948. Plua curcullo control. Va. State Hort. Soc. Proc. (1947) $36(1): 56-63$.

(39)

1949. Spray for control of the peach tree borer. Jour. Ilcon. Int. 42: 343-345.

(40) - - and Grayson, J. $M$.

1947. New materials tested on plam curculio. Va. Agr. Hexpt. Sta. Ann. Rpt. (1946-1947): 30.

(41) Bondj, I. F.

1947. Results obtained from the use of various insecticides in boll weerll control, 1946 and 1947. Pee Dee Experiment Station, Florence, South Carolina. Southeastern Cotton Insect Control Conference Proc., Columbia, S. C. Dec. 8-9, 1947, pp. 10-17.

(42) Bourne, B. 1.

1948. Iffects of benzene hexachloride and chlordane on the germination of sugar-cane cuttings. Sugar Jour. 10(8): $3-4,20$.

(43) Brannon, I. Y.

1949. Tests of some new insecticides to contfol Mexican bean beotle. Jour. Icoi. Ent. 42: 928-930.

(44) Brott, C. H., and Bloades, W. C.

1946. Control of the red harrester ant with Volsicol 1068. (Sci. note.) Jour. Econ. Int. 39: 663-664.

(45) -...- and Bhoades, W. C.

1946. Grasshopper control in alfalfa with hexachlorocyclohexane dust. (Sci. note.) Jour. Econ. Int. 39: 677-578.

(46) -... and Rhoades, W. C.

1947. Boll weeril control with chlordane, benzene hexachloride, and calcium arsenate dusts. (Sci. note.) Jour. Econ. Ent. 40: 572-574.

(47) -....- and Rboades, W. C.

1.948. Grasshopper control with parathion, benzene hexachloride, chlorinated camphene, and chlordan. Jour. Icon. Int. 41: 16-18. 
(48) Brooks, J. W., and Lnderson, I. D.

1947. Toxicity tests of some now insect1e1des. Jour. Econ. Ent. 40: $220-228$.

(49) Brown, A. K. L.

1947. Control of Melanolus mexlcanus from aircraft vith o1l balt contalning chlordano. (Sc1. not.) Jour. Icon. Int. 40: 607 .

(50) -... Eороwell, Y. M., Menner, B. J., and MaDonald, H. 1948. Laboratory assessment of organic lnsect1cides for control of cortain lepldopterou larrao. Can. Entomolog1st 79: $161-166$.

(51) -... and Hurt1g, E.

2347. Organle insecticidos for the losser nigratory locust. (Sc1. noto.) Jour. Bicon. Int. 40: 276-277.

(52) - - Boblason, D. B. W., Hrut1e, H., and Weaner, B. J. 1948. Toxicity of selected organ1c corpound to 1nsects. I. Tents for general toxlcity on larra of Musca, Tribolium, and Fphest1a, and adul to of Sitophilus. Canad. Jour. Res. Sect. D., Zool. Sc1. 26: 177-:187.

(53) -.. Menner, B. J., and Park, I. $\mathbb{E}$.

1948. Torfelty of solected organle compound to insects. II. Test for contact toxicity on wrobs of Blatella and Oncopeltis, and adults of Tribolium. Canad. Jour. Bos. Sect. D., Zool. Sc1. 26: 188-196.

(54) Bruce, X. 3.

1949. Characteristics of residual 1nsecticides toxic to the house fly. Ill. Hat. H1st. Surve Bul. 25: 1-32.

(55)

1950. Current report on bousefly resistance to insect1c1des. P•st Control 18(4): 9-10, 19.

(56) - - and Docisor, G. C.

1948. My control and m1lk Now. Jour. Icon. Int. 40: 530-536.

(57) Basbland, R. C.

1948. Insect1cidos for the control of lice attacking and animals. Internatl. Cong. Trop. Med. and Malar1a $\Delta$ bs. 4: $138-139$.

(58) …- Woll., B. W., and Radoleff, R. D.

1948. Iffect on Iirestock of spreys and dip contalnine nex chlorinated 1nsect1c1des. Jour. Icon. Int. 41: 642645 .

(59) Bussart, J. E., and Schor, A.

1948. Chlordano. Soap and Sant t. Chem. 24(8): 126-128. 
(60) Butcher, F. D., Wilbur, D. A., and Dahm, P. A.

1950. A comparison of the grasshopper killing effectiveness of chiordano, toxaphene, parathion, and compound 118 sprays and sodiun fluosilicate bait in Kansas in 1948. Kansas Ent. Soc. Jour. 23(1): 22-26.

(6I) Brtler, G. D., Jr., and Carruth, L. A. 1949. Corn earworm control with DDT and other insecticides. Jour. Icon. Int. 42: 457-461.

(62) - - and Shan, I. R.

1948. Comparative toxicity of various insecticides to the honoyboe. Gleanings Bee Cylture 76: 348-349.

(63) Bynum, I. K., Ingram, J. W., and Charpentier, I. J. 2949. Control of u1reworms attacking sugar cane in Louisiana. Jour. Icon. Int. 42: 556-557.

(64) Carpiell, J.

1948. Promising new chemicals for the control of potato disease and insects. Amer. Potato Jour. 25(2): $48-49$.

(65) Carlson, F. W., and Newcomer, $\mathbb{E} . J$.

1949. Control of pear psylla in the Pacific Horthwest. Jour. Ireon. Int. 42: 338-342.

(66) Carrath, I. A., and Howe, H. I.

1948. Factors affecting use and phytotoxicity of DDT and other insecticides for squasb borer control. Jour. Econ. Ent. 41: 352-355.

(67) Carter, B. H., Wells, B. W., Badeleff, B. D., Smith, C. I., Hrobanis, P. F., and Mann, B. D.

1949. The chlorinated hydrocarbon content of milk from cattle sprayed for control of horn flles. Jour. Econ. Int. 42: 116-118.

(68) Chamberlin, T. R., and Medler, J. T. 1949. Tests of 1nsecticides against the meadow spittlebue on soed alfalfa. Jour. Econ. Int. 42: 653-656.

(69) -... Medler, J. T., and O'Heal, I. J.

1948. Insecticides for control of spittlobus nymps in Wisconsin. Jour. Bcon. Int. 41: 509-510.

(70) Chandlar, s.

1950. Peaches - Parathion and aldrin rank high as corcul 10 controls. The Packer. Hew York th. Feb. 4, p. 11.

(71) Chandler, S. C.

1948. Plum curculio control with chlordane and benzene bexachloride. Down to Farth [Dow Chomical Co.] 4(1): $14-15$. 
(72) Chandler, S. C.

1948. Control of pack cat-facing in Ill1no1s. Jour. Econ. Int. $41: 52-55$.

(73)

1949. Chlordan and bonzen hexachloride for the cantrol of plum curcul10 [Conotracbelus nonuphar] on pesch. (Abs.) Assoc. South Ag. Workers Proc. 46: 92.

(74) 1949. Chlordan and benzene horachloride for control of plum curcul10 on peach. Jour. Icon. Ent. 42: 514-518.

(75) -1950. A comparat1re study of insect1c1des for control of plu curcul 10. Jour. Econ. Ent. 43: 73-75.

(76) Ch1sholm, R. D., and Mason, A. C.

1948. Ithylene dibrom1d-chlordane d1p for treat1ng plant balla infested vith varlous stages of the Japanese beetlo. U. S. Bur. Ent. and Plant Quar. E-757. 2 pp. [Processed.]

(77) Cbrist, E. G., and Drigger 8, B. F.

1949. Strawberry weevil control with new organic 1nsecticides. Jour. Econ. Ent. 42: 559.

(78) Colorado D171810n of Agriculture

1949. Colo. Dir. Agr. Ann. Bpt. 1946-1947. Hessian FlJ, pp. 19-24.

(?9) Compton, C. D.

1949. For control of so1l 1nsects - chlordane in fertilizer. Agr. Chem. 4(5): 29, 93.

(80) Cope, O. B.

1949. Toxic1ties and tolerances of now 1nsecticides in relation to wildlife and f1sh. Cal1f. Mosquito Control Assoc. Proc. and Paper 1948: 26-29.

(81) Cotton, B. T., and Frankenfold, J. C.

1948. Residual - toxic1ty tudies with new types of 1nsect1c1dar sprays. Amer. Miller and Processor 76(4): 45-46; and (7): 36,38 .

(82) -.-- and Trankenfeld, J. C.

1948. Laboratory experiments with resicual spreys for control of confused flour beetlos in the flour mill and warehouse. Assoc. Oper. Millers Bur., Apr. 1948. pr. 1660-1665. 
(83) Cotton, R. T., and Frankenfold, J. C., and Dennis, N. M. 1948. Residual spress for use against the confused flour beetle. U. S. Bur. Fint. and Plant Quar. I-766. $15 \mathrm{pp}$. [Processed.]

(84) Cox, J. A.

1949. Field experiments for control of the grape berry moth. Jour. Econ. Bnt. 42: 507-514.

(85)

1949. Control of plum curculio on prunes. Jour. Econ. Int. 42: $632-635$.

(86)

1949. Control of cherry fruft flies. Jour. Econ. Ent. 42: 702-703.

(87) Creighton, J. T., Hetrick, I. A., Hunt, P. J., and Duncan, D. U. 1947. The application of chlorinated bydrocarbons to the soll and roosts effectively controls lice of poultry. Poultry Sci. 26: 674-675.

(88) Cristol, S. J.

1950. Insecticidal activity and dehydrochlorination rates of some polychloro insecticides. Adrances in Chem. Series 1: 184-189.

(89) Crosby, J.

1947. Wirewor frmigants tested. Calif. Cult. 94(19): 627-628.

(90) Crowell, H. H., and Morr1son, H. I.

1950. The phytotoxicity to cucurbits of some new insecticides. Jour. Hcon. Ent. 43: 14-16.

(91) -... Morrison, H. B., Crumb, S. E., Jr., and Lauderdale, B. W. 1948. Cabbage maggot control by the use of benzene hezachloride in the soil. Jour. Ircon. Int. 41: 362-365.

(92) Ouff, R. I.

1948. Report farn tests of new fly killers. Successful Farming 46(7): 94 .

(93) Cullinan, F. P.

1947. Iffects of some of the newer or ganic chemicals on plant Iife. Agt. Chem. 2(5): 18-20.

(94)

1949. Some new insecticides - thelr effect on plants and so1ls. Jour. Econ. Ent. 42: 387-391.

(95) Cutkomp, I. I.

1947. Residual aprass to control Anopheles quadrimaculatus. Jour. Econ. Ent. 40: 328-333. 
(96) Cutright, C. R.

1949. Combating the periodical cicada with insecticides. Jour. Econ. Int. 42: 359-362.

(97) Danish, A. A., and Lidov, R. E.

1950. Colorimetric method for estimatine small amounts of aldrin

(corpound 118). Adrances in Chez. Serles 1: 190-197.

(98) Dav1dow, B.

1950. A spectrophotometric method for the quantitative estimation of technical chlordane. Assoc. Off. Agr. Cher. Jour. 33: $886-894$.

(99) Dean, R. W.

1948. Toxicity studies of insecticlies for the control of the apple aggot, Rhagoletis pomonella Kal sh. H. Y. Stete Agr. Expt. Sta. Ann. Rpt. (1947) 66: 14.

(100)

1948. Plum curcelio control with chlorinated byarcearbon insecticides in 1947. Jour. Econ. Ent. 41: $524-525$.

(101) Decker, G. C., Welnman, C. J., and Bann, J. M.

1949. A preliminary report on the rate of insecticide residue loss from treated plants. Presented as Exh1b1t lio. 904, Food and Drug Administration Hearings on Residue Tolerances. Julius Hyman \& Co., Denver. 9 pp., 9 fie. Dec. [Processed.]

(102) Dowey, J. E., and Van Geluwe, J. D.

1948. Some organic insecticlies for control of plum curculio

on peaches. Jour. Econ. Ent. 41: 235-239.

(103) Diotz, A.T.

1949. Farm fiy control in Los Angeles county. Cal1f. Univ. Citrus Expt. Sta. News Lotter No. 38, 2 pp. April.

(104) Dills, I. I., and Odland, M. L.

1948. Cabbre maget insecticidal tests. Jowr. Econ. Ent. 41: 98-101.

(105) _... and Odrand, M. I.

1948. Cabbace caterpillar insecticide tests. Jour. Icon. Bnt. 4I: $948-950$.

(106) -... and Odland, M. I.

1948. Seraral chemicals better than mercury compounds in combat1ng cabbage mrggot. Sclence far the Farmer Supplement No. 2, Bul. 488, pp. 9-10.

(107) -... and Odland, K. L.

1949. Cabbace caterp1liar insect1cido orperints. Market

Grower: Jour. 78(6): 19 . 
(108) Dobbins, I. I., and Pronik, W. D.

1948. Insecticide hests for the control of coleopterous laxva attacking pesmat: in the soil. Jour. Icon. Int. 41: $815-816$.

(109) Dogger, J. R., and Lialy, J. I.

1949. Seed treatrent as a rean of raducine wireworm damage to corn. Jour. Icon. Bnt. 42: 663-665.

(110) Dominick, C. B.

1949. Hew 1nsecticldes for tobacco flea batlo control. Jour, Icon. Int. 42: 148-149.

(11I) Dorst, H. I., and Peag, K. B.

1949. Insecticides not effectire in control of curly top in tomstoes. Farm and Home Science. Utain Agr. Fixpt. Sta. $10(1): 16$.

(112) Douglass, J. E., and Shirck, F. H.

1949. Bxperiments for control of onion tarkp. Jour. Escon. int. 42: 68-72.

(113) Doyle, I. A., and Dureen, J.

1949. Coaparison of calcium arsenate, chlordane, lethane, and DDT in the control of potato insects. Ontarto ent. Soc. Ara. Bpt. (1948) 79: 22-24.

(114) Driggers, B. F., and Darley, M. M.

1949. Control of plum curculio on peachos with benzens bexachloride, paratbion, cblordan, and loal sr senate. Jour. Ircon. Int. 42: 330-335.

(115) _... and Merrill, Jr., I. G.

1949. Oriental fruit moth control with DDT and parathlon. Jour. Iicon. Ent. 42: 351-354.

(116) Dugas, A. I., Smith, C. E., and Concionne, I. J.

1947. Velvetbean caterpillar control on sogbeans. La. Agr. Brot. Sta. Ann. Bpt. 1945-1946: 54-55.

(117) -- Smith, C. I., and Concienne, I. J.

1948. Sugarcane insect control. La. Agr. Expt. Sta. Ann. Bpt. 1946-1947: $54-55$.

(118) -...- Smith, C. E., and Conclenne, I. J.

1948. Velretbean caterp1llar. La. Agr. Expt. Sta. Ann. Lipt. 1946-1947: 55-56.

(119) --. Smith, C. I., and Concienne, B. J.

1949. The new organic insecticides are vnsafe to use on sugar cane in Loulsiana for sagar cane borer control. La. Agr. Expt. Sta. Ann. Rpt. 1947-1948: 69-70. 
(120) Daeas, A. L., Sm1th, C. E., and Concienne, E. J.

1949. Parathion found effective agalnst the fall ararwora and the lesser cornstalk borer. La. Agr. Expt. Sta. Ann Rot. 1947-1948: 70-71.

(121) Dustan, G. G., Arustrong, T., and Putman, W. L.

1947. The influence of air currents on the insecticidal action of DDT, benzene hexachlor1de, Eercules Tozdcent 3956, and Pelsicol 1068. Canad. Int. 79: 45-50.

(122) Eckert, J. E.

1948. The present relat1on of aricultural chemicals to beekeeplng 1ndustry. Amer. Bee Jour. 88(3): 129-131, 143-144.

(123)

1948. Toxiclty of some of the newer chemicels to the honeybee. Jour. Econ. Ent. 41: 487-491.

(124)

1949. Dotermining toxicity of acricultural chomicals to honeybees. Jour. Econ. Ent. 42: 261-265.

(125) -... and Kest, M. C.

1948. Chlordane $\mathrm{V} 8$. bees and ants. Amer. Ber Jowr. 88: 584.

(126) Eddy, G. H., and Bushland, B. C.

1948. Compornds more tox1c than DDT to body 11ce. Jour. Icon. Ent. 41: 369-373.

(127) -... and Graham, C. H.

1949. Tests to control horn flles with nev 1nsect1cides. Jour. Econ. Ent. 42: 265-268.

(128) _... and McGregor, K. S.

1949. Res1dual act1on of organic insecticidos against stable fl1es. Jour. Econ. Ent. 42: 547-548.

(129) Bdon, W. G., and Arant, F. S.

1949. Control of the 1mported f1re ant in Alabans. Jour. Icon. Int. 42: 976-979.

(130) Edgar, S. A.

1948. Comparative efficacy of everal old and now insect1c1dos and bethods of application in the control of l1ce on ch1ckens. Assoc. South. Workers Proc. 45: 149-150.

(131) --. Walsh, W. L., and Johnson, L. W.

1949. Comperat1ve off 1cacy of sereral 1nsect1c1des and metbods of application in the control of lice on chickens. Poultry Sc1. 28: 320-338. 
(132) sido, P. M.

1947. Bxperimenta with Ingecisicides on honegbees. Jour. Econ. Int. 40: 49-54.

(133) Mlis, D. I.., and Clayton, C. I.

1948. So12 treatment 8 with now insectscides ineffective in control of root-knot. Plant Dia. Iptr. 32i 476-477.

(134) Bwart, H. E.

1949. The preaent status of the ure of new insecticides on c1trus in central California. Part I - C1trus tirlps and citricola scale. Calif. Unir. Citrus Expt. Sta. Hews Letter 39: 2-6. [Procossed.]

(135) Tairchild, ‥ F., Hoffman, R, A., and Iindquist, A. W. 1949. A comparison of the cislorinatge hrdrocarbon insecticide for control of the sheop tick. Jour. Mcon. Bnt. 42: $410-414$.

(136) Fey, R. W., Colo, E. I., and Buckner, A. J.

1947. Comparative residual exiectireness of organic insect1cides against house 1]10s and malaria nosquitoes. jour. Econ. Ent. 40: 635-6́d0.

(137) Fife, L. C., Chapman, A. J., and Shiller, I. 1948. Torictty of several chlorinated hydrocarbons to thripg on cotton. Jour. Econ. Int. 41: 665-66́.

(138) --.- Waiker, R. I., and Bondy, F. F.

1949. Boll weevil control with several organic insecticides during 1948. Jour. Econ. Int. 42: 682-684.

(139) Fleming, W. I.

1947. Chlordane for contrel of Japanese beetle larrae in turf. (Sci. note) Jowr. Eicon. Int. 40: 932-933.

(140)

1948. Chlordane for control of Japanese beetle larrae. Jour. Econ. Fint. 41: 905-912.

(141) Foyd, E. H.

1947. Control of tho tomato frait worm in 1946. Jour. Econ. Bnt. 40: 422-42.3.

(142) (-...

1947. DDI and crgolite successful in controlling the tomato fruitworm. La. Agr. Brpt. Sta. Ann. Bpt. 19451946: $55-56$.

(143)

1949. Control of the sand wireworm in Loulsiana. Jour. Bcon. Ent. 42: 900-903. 
(144) Moyd, I. H.

1949. Poвaible product1on of late-season roasting ears by use ol paratbion. La. Agr. Expt. Sta. Ann. Bpt. 1947-1948: $71-73$.

(145) - w and Salth, C. E.

1949. Chlordano as a soll treatment compares fararably with calcian arsenate as a ccntrol for the sreot potato veer11. La. Agr. Expt. Sta. Ann. Bpt. 1947-1948: 71.

(146) - - and Smith, C. E.

1949. Promising results obtalned by sereral 1nsecticides in the control of thrips on onfons. La. AEr. Expt. Sta. Ann. Rpt. 1947-1948: 74.

(147) -... and Smith, C. I.

1949. Control of seed-corn mageot and southern corn rootworm 10 corn 1ncreases j1elds. La. Agr. Brpt. Sta. Ann. Rpt. 1947-1948: 74-76.

(148) -. and Smith, C. E.

1949. An economical and practlcal means of control for the sand wireworm. La. Agr. Brpt. Sta. Ann. Rpt. 1.9471948: 76-77.

(149) -... and Smith, C. E.

1949. Control of the southern corn rootworm and the seed-corn maggot in Iouisiana. Jour. Econ. Ent. 42: 908-910.

(150) Mano, J. A., Rarn, I. S., Deonier, C. C., and Faulker, F. 1949. Comparative toxicity of DDT and some of the newer insect1c1der to adults of salt-marsh mosquitoes. Mosquito Hows 9(1): 15-18.

(151) Foster, A. C.

1948. Phytotoxic effect of DDT and other chlorinated hydrocarbon insecticides. Assoc. South. Agr. Wor sers Proc. 45: 143-144.

(152) Fowler, R. G., Jr.

1948. Chlordano gets r1d of roaches. Oreg. Farmer 71: 552553.

(153) Fox, C. J., St1rrett, C. M., Arnott, D. A., and Wressell, B. B. 1949. Chenical control of tho tomato hornworm on tobacco in Ontar10. Sc1. Agr. 29: 553-562.

(154) Fraz1er, N. W., and Barnes, D. F.

1948. Trperlunt for control of the exape leal folder in Cal1fornia. Jour. Econ. Ent. 41: 441-442. 
(155) Frear, D. D. H.

1949. What the dealer ahould know about insecticides. Agx. Chen. $4(5): 25-28,85$.

(156) -.... Hilborn, M. T., and Prince, A. E.

1949. Pest control material s, 1949. Maine Agr. Expt. Sta. Misc. Publ. 513: Pa. Agr. Expt. Sta. Progress Rpt. 4: $110 \mathrm{pp}$.

(157) Frezal, M.

1948. Sur l'action insecticlde de I'octochlornaphtalene. Acad. d'AET. de France Compt. Bend. 34: 556-660.

(158) Hinga, H., and O'Tousa, J. I.

1950. Toxicity to mice of chlordan vapor and solutions administered cutaneously. Science 111: 658-560.

(159) Fronk, W. D., and Dobbins, T. N. 1949. Insecticide tests for control of the southern corn rootworm in peanuts. U. S. Bur. Int. and Plant Quar. E-782. $10 \mathrm{pp}$. [Processed.]

(160) Tuiton, R. A., MeBride, O. C., and Sullivan, W. N.

1949. Toxicity of residues from carbon dioxide-propelled insecticides. Jour. Icon. Bnt. 42: 123-126.

(16I) Furman, D. P., and Douglass, J. B.

1948. Comparative evaluations of insecticides for cattle grab control. Jour. Bcon. Ent. 41: 783-787.

(162) Gahan, J. B., Gilbert, I. H., Peffly, R. L., and Wilson, H. G. 1348. Comparative toxicity of four chlorinated organic compounds to mosquitoes, hous e flies, and cocioroaches. Jour. Econ. Ent. 41: 795-801.

(163) Gaines, J.C.

1947. Tests of insecticides for control of grasshoppers. Jour. Beon. Bnt. 40: 896-899.

(164) -... and Dean, H. A.

1948. Tests of insecticides for the control of several cotton insects. Jour. Econ. Ent. 41: 548-554.

(165) -... and Dean, H. A.

3.948. Comparison of insecticides for control of harlequin bugs. Jour. Econ. Ent. 41: 808-809.

(166) and Dean, H. A.

1948. Comparison of insecticide dusts for grasshopper control. Jour. Bcon. Ent. 41: 945-348. 
(167) Galnes, J. C., and Dean, I. A.

1949. Effect of temperature and humidty on the toric1ty of certain 1nsect1c1des. Jour. Icon. Ent. 42: 429-433.

(168) -... and Dean, B. A.

1949. Insecticlde tests for boll weev1l control durine 1948. Jowr. Bcon. Ent. 42: 795-798.

(169) -... and Dean, H. $\Delta$.

1949. Comparison of sprays and dust for frashopper control. Jour. Icon. Int. 42: 956-359.

(170) Galnes, R. C., and Scales, A. I.

1948. Iffectiveness of insecticides on the boll weerli in cotton squares in 1947. Jour. Bcon. Int. 41: 519-520.

(171) Gambrell, I. I., and Mason, A. C.

1948. Insect1c1dal and phytotox1c propert1es of plant dips usod to control the Iuropean chafer. Jour. Econ. Int: 41: $258-263$.

(172) Gates, I. I.

1949. Preliminary test for chlordane residue on alfalla. Bureau of Plant and Insect Control, 3-1-49, Denver, Colorado, $5 \mathrm{pp}$. [Processed.]

(173) Gersỏorff, W. A., Nelson, R. H., and Miklin,.. 1950. Culorinated hjdrocarbons - the relative toxicity of beptachlor, aldrin, and dieldrin to house flies whon applied as space spraya usine Campell turatable metiod. Soap and Sanit. Chem. 26(4): 137, 139.

(174) G11bert, B. 0 . 1948. Chlordane, a pest control. I. A. County Bealth Dept. Public Healtin News - Neakly Health Article 102. July 7. 1948. 1 p. [Processed.]

(175) Ginsbarg, J. M.

1947. Tosts with new toxicants in comparison with DDT on mosquito larvae and f1sh. N. J. Mosquito Extermin. Assoc. Proc. (1947) 34: 132-135.

(176) GJullin, C. M.

1949. Laboratory tests with various now 1nsecticldes against the shoop t1cir. Jorr. Icon. Int. 42: 984-935.

(177) -... Cope, 0. B., Qu1sonberry, B. F., and DuCharo1s, F. B. 1949. The effect of some insecticides on black fly larvae in Mlaskan streams. Jour. Econ. Ent. 42: 100-105. 
(178) Gjullin, C. H., W1lson, C. S., Travis, B. V., and Eutton, G. I. 1949. The relative offectiveness of sereral insecticides againgt mosquito lamae in Alsaka. Mosquito Nows $9(4): 142-145$.

(179) Glass, I5. H., and Chapman, P. J.

1949. Red-banded leaf roller problem in Hew Tork. Jour. Iicon. Int. 42: 29-35.

(180) Goldman, I.

1947. Progress report no. I [on the reaction of the skin of human subjects to contact with $\nabla e l$ sicol 1068]. Velsicol Corp. Tech. Bur. 211. 2 pp. [Processed.]

(181) Goldgworting, M. C.

1948. Iffect of soll applicat1ons of varlous chlorinated hydrocarbons on the top growth of Blakemore strawberry plants. Plant D18. Rptr. 32: 186-188.

(182) Gould, I., and Taylor, C. E.

1949. Effect of insecticidal sprays on incldence of peach scab in West Virginia. Plant Dis. Rptr. 33: 16-17.

(183) Govld, G. I.

1947. The control of cockroaches. Ind. Agr. Ixpt. Sta. Ann. Bpt. (1946) 59: 52-63.

(184)

1947. Her chemicals are promising insecticides. Ind. Agx. Expt. Sta. Ann. Rpt. (1946) 59: 64-65.

(185)

1947. Some notes on the blology and control of tomato hornworms. Ind. Acad. Sc1. Proc. (1946) 56: 157-162.

(186)

1948. New Insecticides show promise. Ind. Agr. Expt. Sta. Ann. Rpt. (1947) 60: 69.

(187)

1948. Tomato hornworm studies. Ind. Agr. Expt. Sta. Ann. Rpt. (1947) 60: 70 .

(188)

1948. DDT eliminates potato leafhoppers. Ind. Agr. Expt. Sta. Ann. Rpt. (I947) 60: 70.

1948. Jew Insecticides show promise of roach control. Ind. Agr. Brpt. Sta. Ann. Rpt. (1947) 60:72. 
(190) Graham, C.

1943. Control of Easshoppers in apple and poach orchards. Jour. Ecsn. Ent. 41: 121.

(191)

1949. Control of the red-banded lesf roller. Jowr. Bcon. Ent. 42: $354-356$.

(192) Grabam, 0. B.

1949. An attemp to protect cattle from grub infestation by use of 1asect1c1des. Jour. Econ. Ent. 42: 83?.

(193) -... and Iddy, G. K.

1948. Persistence of chlorinated camphen as a fleece vorm larv1c1de. Jour. Econ. Int. 41:521

(194) Granoriky, A. A.

1948. Hew chomicals for catworm control. Minnosota Farm and Home Sclonce 5(2): 1 .

(195) Croenvood, D. S.

1948. The status of Wreworm control, Connect1cut, 1947. Conn. Ag. Expt. Sta. Spec. Bur. , Feb. 15, 1948, 3 pp. [Procersed.]

(196) Greenwood, M. I., and T1ce, J. M.

1949. Palatab1lity tests of potatoe grow in so1l treated with the insecticides benzene bexachloride, chlordan, and chlorinated camphene. Jour. Agr. Research 78: $477-482$.

(197) Griffitie, J. T., Jr., and Bing, J. B.

1948. Comparat1ro coupat1b1lity and residual toxicity of organlc insect1cides as based on Erasbopper control. Jour. Econ. Ent. 41: 389-392.

(198) -... K1ng, J.R., and Thompon, W. I.

1947. Grasshopper control 1n c1trus groves in Morida. Ma. State Eort. Soc. Proc. (1947) 60:80-36. Also in C1trus Ind. 29(4): 20-22, 26. 1948.

(199) Gyr1sco, G. G., and Marshall, D. S.

1950. Further 1avest1gat1ons on the control of the clover root borer in New York. Jour. Ecan. Ent. 43: 82-36.

(200) - - Norsom, I. D., Marshall, D. S., and Schwardt, E. B. 1949. Now advances in alfalfa snout bootlo control. Jour. Econ. Ent. 42: 311-314. 
(201) Hamil ton, D. K.

1948. Sumer control of pear psylla during 1947. Jowr. Econ. Bnt. 41: 244-248.

(202) Hamman, R. $\mathrm{E}$.

1948. Factors involved in poisoning German roaches by exposing them to surfaces treated with chlorinated hydrocarbons. Jour. Bcon. Int. 41: 516-517.

(203) Hansens, E. J., and Goddin, A. H.

1949. Reaction of certain fly strains to DDT and methorychlor deposits. Jour. Bcon. Int. 42: 843-844.

(204) ---- Schmitt, J. B., and Barber, G. V.

1948. Resistance of horse flies to residual applications of DDT in Jow Jerseg. Jour. Econ. Ent. 41: 802-803.

(205) Harned, B. H.

1947. The prospects for cotton insect control in 1948. Southeastern Cotton Insect Control Conference Proc., Columbia, S. C., Dec. 8-9, 1947. pp. 28-31.

(206) Harrison, P. K.

1949. Laboratory tests of new compounds as insecticides against the sweetpotato weevil. U.S. Bur. Ent. and Plant Quar. I-770. 5 pp. [Processed.]

(207) Hartzell, A.

1949. Effectiveness of $\mathbb{N - ( 2 - W t b y l h e x y ) ~ B i c y c l o [ 2 . 2 . 1 ] - 5 - ~}$ Heptene-2,3-Dioarboximide on houseflies. Boyce Thompon Inst. Contrib. 15(7): 337-339.

(208) Hastings, E., and Pepper, J. H.

1949. Fleld tests with new insecticides for control of the alfalfa weoril. Jowr. Econ. Ent. 42: 554-555.

(209) Hawkins, J. H., and Thurston, R.

1949. Some phases of thuropean corn borer control in Central Maine. Jour. Econ. Int. 42: 306-311.

(210) Hayslip, I. C.

1948. Recent advances in the control of animal, pasture and corn pests. Everglades Ixpt. Sta., Belle Glade, Fla. Mimeozraphed Rpt. No. 12, 8 pp.

(211)

1948. A report of insect control investigations for the 1iscal year July 1, 1947-1948. Brerglados Expt. Sta., Bello Glade, Fla. Mimeographod Rpt. No. 17, $26 \mathrm{pp}$. 
(212) Hay $811 p, \pi .0$.

1948. Insect control 1nvestigat1ons. Vegetable Crops Field Dav, Indlantown, Fla., Apr. 29, 1948. pp. 3-3. [Processed.]

(213) Eerzfeld, S. H., and Klelman, M.

1950. 1,2-D thydroxy-4, 5, 6,7,8,8-hexahal o-4, 7-me thano-38,4,7,7atetrahydrolndane and method of preparing same. U. S. Patent 2,528,654, dated Nor. 7, 1950; appl. July 22, 1948. [Assigned to Velsicol Corp.]

(214) - - and Ordas, E. P.

1950. 1-Acjloxy -4, 7-methano-3a, 4,7,7a-tetrahydro-4, 5, 6, 7, 8, 8hexachlorolndenes and method of producing the same. J. S. Patent 2,528,655, dated Not. ?, 1950; appl. July 22, 1948. [Assigned to Velsicol Corp.]

(215) -.... and Ordas, E. P.

1950. 1-Eydroxy - , 7-me thano-3a, 4, 7, 7a-tetrahydro-4, 5, 6, 7, 8, 8bexachloroindene and method of preparing same. U. S. Patent 2,528,656, dated Nor. 7, 1950; appl. July 22, 1948. [Asslgned to Velsicol Corp.]

(216) Hetrici, I. A.

2350. The toxicity of some organic insecticides to the eastern subterranean termite. Jour. Econ. Ent. 43: 57-59.

(217) Heyroth, F. F., and W1therup, S.

1950. Toxicity of chlordane in arosols. Chem. Spec. Mfrs. Assoc. Proc. 37: 86-88. Dec. 3-5. [Soap and Sanit. Chom. Special Issue.]

(218) Hinman, E. J., and Cowan, F. T.

1947. New 1nsect1c1des in grasshopper control. U. S. Bur. Ent. and Plant Quar. E-722. 21 pp. [Processed.]

(219) Hixson, E., and Muma, M. H.

1947. Toxdclty of certain insecticides to the chicken mite. Jour. Econ. Ent. 40: 596-593.

(220) Eocisine, B., Twinn, C. R., and McDuffie, W. C.

1949. A prelininary evaluation of some insecticides againgt 1mature staces of blackflios (Diptera Simuli1dag). Sc1. Agr. 29(2): 69-30.

(221) Hoffman, R. A.

1949. Effect of sereral insecticides on sheep tick pupse. Jour. Econ. Ent. 42: 934. 
(222) Hoffman, R. A., and Iindquist, A. W.

1949. Tumigating propertios of several new insecticides. Jour. Econ. Ent. 42: $436-438$.

(223) -.... and Indquist, A. W.

1949. Iffect of temperature on knockajown and mortality of house flies exposed to residues of several chlorinated hrarocarbon insecticides. Jour. Econ. Fnt. 42: 891-893.

(224) -... Roth, A. R., and Iindquist, A. W.

1949. Iffect of air temperature on the insecticidal action of some compounds on the sheep tick and on migration of sheep tick on the animal. Jour. Econ. Ent. 42: 893896.

(225) Hofmaster, B. N., and Greenwood, D. D.

1949. Fall armyworm control on forage and truck crops. Jour. Econ. Int. 42: 502-506.

(226) Howgh, W. S.

1948. Chlordan compared with parathion on plums. Jour. Bcon. Int. 41: 983-984.

(227) -... and Hill, C. H.

1947. Lead arsenate substitutes sought. Va. Agr. Expt. Sta. Ann. Rpt. (1946-1947): 32 .

(228) Howell, D. E., Ilddy, G. W., and Cuff, R. I.

1949. Iffect on horse fly populations of aerial spray applications to wooded areas. Jour. Icon. Ent. 42: 644-646.

(229) Huckett, H. C.

1948. Control of the two-spotted spider mite on lime beans, on Lone Island. Jour. Econ. Ent. 41: 202-206.

(230) Hutson, R.

1948. Grasshopper control in orchards. Mich. State Hort. Soc. Ann. Rpt. (1947) 77: 4I-42.

(231) Eyman, J.

1946. Perfectionnements apportes ou relatifs a une metbode de formation d'une nourelle composition de matiere et produit qui en resulte. Belgian Patent No. 464,617, Apr. 16, 1946.

(232)

1947. Mejoras en una neuva composicion de materia y el metodo de formerla. Mexican Patent No. 45,398, Nar. 19, 1947; applied for Mar. 13, 1946. 
(233) Esman, J.

1949. Improvements in or relating to nethod of formlac halogenated organlc coupound and the products resuit1ng therefron. Br1t. Patent 618,432; accopted Feb. 22, 1949; appl1od for March 19, 1946; in the U. S. A. Jely 25, 1945 and Jan. $26,1946$.

(234) Illino1s Un1rersity College of Agriculture Ixtension Sarvice 1948. Chlordano for grassbopper control. IIl. Agr. Col. Int. IEB 248,1 p. Mar. 31, 1948.

(235) Ingle, I.

1947. Tox1c1ty of chlordane to white rat. Jour. Econ. Ent. $40: 264-268$.

(236) Ingram, J. K., Bynum, E. K., and Charpentier, I. J. 1947. Tests with new Insecticides for control of the sugarcene borer. Jour. Econ. Ent. 40: 779-781.

(237) Iry, E. E., and Bwing, K. P.

1947. Laboratory and cage tests with newer 1neect1c1des to control cotton insect. (Sc1. note) Jour. Econ. Ent. 40: 568-569.

(238) Jacobs, J. J.

1949. Chlordan and dermit1t1. Pest 17(1): 13-14.

(239) Jofferson, R. N., and Ponce, R. J.

1948. Aster leaf miner-chlordane and benzene berachlorido promising as control insecticides. Cal1f. Agr. [Cal1f. Agr. Expt. Sta.] 2(1): 11-12.

(240) - - and Pence, R. J.

1948. Preliminary experiments on the cantrol of the leaf-miner

Inlemy flaveola on aster 8. Jour. Econ. Int. 41: 653-655.

(241) Jenkins, J. M., Jr.

1948. Stat1on resumes flower rasearch. Worth Cerolina AG.

fupt. Sta. Research and Farming $7(2): 12,15$.

(242) Johansen, C., and Breakey, E. P.

1949. Control of the or ange tortrix on red raspberries. Jour. Econ. Int. 42: 911-914.

(243) Johnson, D. R.

1949. Chemlcal treatment of seed corn for control of Afopoderns commin. Jour. Econ. Ent. 42: 801-805. 
(244) Jones, S. C., and Rosenstiel, R. G.

1948. Parathion for control of the two-spotted mite and certain insects. Jour. Econ. Int. 41: 118.

(245) Zearns, C. Y., Inele, I., and Metcalf, B, I.

1945. A new chlorinated hydrocarbon insecticide. Jour. Econ. Int. 38: 661-668.

(246) -.... Weinman, C. J., and Decker, G. C.

1949. Insecticidel properties of some new chlorinated organic compounds. Jour. Econ. Int. 42: 127-134.

(247) Zelding, J., and Van Dewrs, H.

1949. DDT resistance in hoveflies in Denmark. Nature [Loncion] 163: $964-965$.

(248) Bolsheimer, I. G.

1947. The control of tomato insects. Market Growers Jour. $76(12): 16,23$.

(249)

1947. The use of some organic insecticides in the control of earworms attacking sweet corn. Ila. State Hort. Soc. Proc. (1947) 60: 121-123.

(250) 1947. Chlordane controls mole-crickets. Fla. Agr. Expt. Sta. Press Bur. 640. 3 pp.

(251)

1948. Chlordan for the control of mole-crickets on lawn and golf courses. Mimely Ther Topics, Jan. 1948. p. 4.

(252)

1948. Chlordan - a usefol insect1cde in southern agriculture. Down to Earth (Dow Chem. Co.) 4(2): 2-3.

(253) 1948. Insect pest on lawns. Fla. Agr. Hxpt. Sta. Press Bur. 642. $4 \mathrm{pp}$.

(254) (--.-

1948. The control of Insect pests of cucurber and squash. Market Growers Jour. 77(12): 16, 27.

(255)

1949. Control of insect pests of cucumber and squash. Fla. Agr. Bxpt. Sta. Bur. $465,15 \mathrm{pp}$. 
(256) Zelskeimer, E. G., Eay sl1p, \$. C., and Wilson, J. W. 1950. Control of budworms, earworms, and other insects attacking sweet corn in Florida. Fla. Agr. Expt. Sta. Bul. 466 , $38 \mathrm{pp}$.

(257) Eentucky Africultural Bxperiment Station

1947. Insect 1njury to peackes. Ky. Agr. Expt. Sta. Ann. Bpt. (1947) 60: 52-53.

(258) - 1948. [Control of varfous insects with chlordano.] Gy. $\Delta$. Expt. Sta. Ann. Rpt. (1948) 61: 10, 14-15,29, 35, 36, $48-49$.

(259) Kerr, T. W., Jr.

1948. Control of the cornfleld ant in golf eens. Jour. Econ. Ent. 41: 48-52.

(260)

1950. Insecticides for control of certain 1nsects attacking ornemental trees and shrubs. Jour. Ecor. Int. 43: $63-65$.

(261) Findler, J. B., and Regan, F. B.

1949. Larricide tests on blackfiles in Nev Hamphire. Mosulto News 9: 108-112.

(262) King, J. B., and Giffiths, J. T., Jr.

1948. Results of the use of concentrated sprogs in citrus groves in Florida. Florida Entomologist 31: 29, 31-34.

(263) King, W. V., and Gahan, J. B.

1949. Fallure of DDT to control house flles. Jour. Econ. Ent. 42: $405-409$.

(264) Inipling, E. F.

1947. Newer syntbetic 1nsecticides. Soap and San1t. Chem. $23(7): 127,129,131$.

(265)

1947. Recent derelopments in 1nsect1cides of 1nterest to pest control operators. Pests 15(2): 10, 12, 14 .

(266) --.- Busbland, R. C., Babers, F. H., Culpepper, G. H., and Raun, I. S.

1948. Evaluation of selected 1necticides and drugs as chexotherapeut1c acents arainst external bloodoucking parasites. Jour. Parasitolog 34: 55-70.

(267) Knowlton, G. F.

1947. Boduce bee 10sses. Bookeepers' Maf. 10(10): 27-28. 
(268) Krijgsman, B. J., and Berger, N. E.

1949. A simple method for the estimation of contact insecticides. Bul. Bnt. Res. 40: 355-358.

(269) Zruse, C. W.

1948. Boach control. Soap and Sanit. Chem. 24(11): 131, 133. $135,137,139,169$.

(270) Kulash, W. M.

1947. Benzene bexachloride, DDT, and chlordane for Colorano potato beetle control. Jour. Econ. Ent. 40: 640--643.

(27)

1947. Results obtained from use of vartous insecticides in cotton insect control at North Carolina Experiment Stations. Southeastern Cotton Insect Control Conference Proc. Columbia, S. C., Dec. 8-9, 1947, pp. 19-22.

(272) - 1947. Benzene hexachloride and chlordane to control cotton boll weevil. Jour. Econ. Ent. 40: 644-650.

(273)

1948. New insecticides for corn earworm control. Jour. Econ. Ent. 41: $387-389$.

(274) -1948. Dust treatments for fall armyworm control in North

Carolina. Jour. Econ. Ent. 41: 822-823.

(275)

1948. Hew insecticides for cotton insect control. Jour. Econ. Iint. 41: $986-987$.

(276)

1948. Wireworm - enemy of row crops. North Carolina Agr. Expt. Sta. Research and Farming $7(2): 4-5$.

(277) -1949. Further tests witlo soll insecticides to control southern corn rootworm. Jour. Econ. Ent. 42: 558-559.

(278) - 1949. Soil insecticldes for control of cutworms. Jour. Econ. Ent. 42: 705-707.

(279) Ryd, S.

1948. New insecticides for grasshopper control. Okla. Agr. Col. Ext. Cir. 483. 3 pp. 
(280) Laake, E. W.

1949. Chlorinated hydrocarbon insecticides for the control of the horn fly on beef cattle in Ransas and Missouri. Jour. Econ. Ent. 42: 143-144.

(281) Laneo, W. H., Jr.

1947. Now developments in so1l insecticider. Agr. Cher. 2(9): $20-23,68-69$.

(282) -... Carlson, E. C., and Leach, I. D.

1949. Seed treatments for wireworm control with particular reference to the use of lindane. Jour. Econ. Ent. 42: $942-955$.

(283) -... and Smith, I. M.

1947. Control of a leaf miner on peas. Jour. Econ. Ent. 40: $496-499$.

(284) Iangford, G. S., and Squires, D. W.

1947. DDT, benzene, hexachl oride, and chlordane for Japenese beetlo control. Jowr. Econ. Ent. 40: 269-270.

(285) Laudan1, H., and Marzke, F. O.

1949. Toxiclty to fabric insects and resistance to wasing and dry cleaning of six chlorinated hydrocarbon insecticides. Jour. Eicon. Ent. 42: $434-436$.

(286) LegG, J.

1949. A preliminary note on the use of two recently introduced insecticides, chlordane and toxaphene, in the control of the cattle tick (Booph1lus microplus). Austral. Vet. Jour. 25: 65-66.

(287) Lehman, A. J.

1948. The pharmacology of the newer 1nsecticices. U. S. Food and Drug Adm. 3 pp. [Processed.]

(288)

1948. The toxicology of the newer agricultural chemicals. Assoc. Food and Drug Official. U. S. Quart. Bul. 12(3): 82-89.

(289) 1948. The toxicology of the newer insecticides. Interratl. Cong. Trop. Med. and Malar1a Abs. 4: 139-140.

(290)

1949. The major toxic actions of insect1cides. Bul. N. Y. Acad. Med. 25(6): 382-387.

1949. Toxic action of 1nsect1clder. Soap and Sanit. Chax. BIue Book 1949, 173-175: Amer. Profess. Pharmac1 at 15: 907$311,938-939$. 
(292) Lohroan, A. J.

1949. Pharmacological constiderations of insecticides. Assoc. Food and Drue Officials,0. S., Quart. Bul. 13(2): 65-70.

(293)

1949. The taxicolog of tho never afoicultural chemicala. Posts 17(1): 7 .

(294) -aro. Classiflea posticidon from public bazard atandpotnt. Food Packer 3I(7): $34-35$.

(295) (-.-

1950. Some toxicological reasons why certain chemicala mag or may not be permitted as food additives. Assoc. Food and Jrug Officials, U. S., Quart. Bul. 14(3): 82 .

(296) Lemmon, A. B.

1948. Bio-asegy of conomic poison. Pests $16(12): 10,12,14$.

(297) Lepage, B. S., Giannotti, O., and Orlando, A.

1947. Experinents on the chemical control of the South Axerican migratory locust Schistocerca cancellata Serv. Inst. B101. [Sa.o Pavlo] Arch. 18(8): 135-160.

(298) Iidor, R. E., Bnous, B., and Beckwith, C.

1948. Mmisifiablo concentrates of chlordane. Soap and Sanit. Chem. 24(3): 137-139.

(299) Iinduska, J. P., and Surber, E. W.

1948. Iffects of DDT and other insecticides on fish and wildlife - Summary of investigations during 1947. U. S. Dept. Interior Fish and Wildifie Serr. Cir. 15, pp. $1-19$.

(300) Linsley, R. G., and MacSwain, J. H.

1947. Effects of DDT and certain other insecticides on alfalfa pollinators. Jour. Jcon. Int. 40: 358-363.

(301) Iist, G. M., and \#oerner, J. L.

1947. Dusts and sprays for grasshoppor control. Jour. Econ. Int $40: 138$.

(302) Lord, K. A.

1950. The effects of concentration of poison and the amount applied on the toxicity of insecticidal dusts to adult Tribolium castaneum Fbst. Ann. Appliod Biol. 37: $123-126$. 
(303) Limsion, D. F., end Szith, F. I.

1943. Growth res.onses by kalanchoos to DiT and other syathetic compounds. Proc. Amer. Soc. Hart. Sc1. 51: 619-522.

(304) Ijle, C., and Fortune, I.

1948. Notes on an 1rmorted f1ro ant. Jour. Ncon. Int. 41: $833-834$

(305) McBrido, O. C., Sullivan, N.N., and Fulton, R. A.

1950. Treatrent of alrplanes to prevent the transportetson o? insects. Jour. Econ. Ent. 43: 66-70.

(306) McCailey, R. E., Jr., Faj, R. W., and Simmons, S. H. 1948. A comparison of the residual effectiveness of certain insecticides against Anophoios cuadr1macu'atuz. liatl. Malar1a Soc. Jour. 7: 294-299.

(307) McDuffie, W. S., Sharp, J. H., Cross, H. F., Tw1an, C. 3., and Wilson, W. $M$. 1949. The offectiveness of prehatching treatments fir tio control of arctic mosquitoos. Mosquito Nows 9: 51-56.

(308) -...- Cross, H. F., Twinn, C. R., Brown, A. H. A., and Itusman, C. শ. 1949. The effectiveness of DDI and other insecticides as Iarricldes againgt arctic specles of Aedeg, Mosquito Iew: 9: 145-149.

(309) Mag1e, R. 0.

1948. Summary of gladiolus experiments in Flor1da, 1948. Fla. Agr. Ixpt. Sta. (Bradenton) Mimsozraph Rpt. 9 pp. Aug. 2 .

(310) -... and Kelshoimer, E. G.

1948. Thrips control test in Florida, 1048. M. Arur. Gladiolus Cour. Bul. 15: 47, 49, 51, 53.

(311) Mail, G. A.

1948. Insoct1cide omilstons easier to ship, safur to zso. Chez. Indus. 62: 233-240.

$(322)$

1343. Housohold 1ngoct1cides. Choz. Indus. 63: 391.

(313) March, R. B., and Metcal , R. L.

1949. Lejoratory and fiold otudios of DDT resistant houscll1c in Southorn California. Cal1f. Dopt. Apr. 3ul. 33: 93-101.

(314) Marshall, D. S., Mevsom, I. D., Gyrisco, G. G., and Sciardt, E. E. 2342. Control of the clotor root borer. Jour. Econ. 3at. it2: $325-313$. 
(315) Marshall, G. \#.

1948. The before hastest story of peach pest control in 1948. Hoosier Hort. 30(10): $247-150$.

(316)

1948. The control of the jor insect pests and diseases of peaches. Ind. Acad. Sc1. Proc. 57: 116-118.

(317)

1949. Interrelation of peach insects and disease control at Orleans, Indiana. Jour. Icon. Tht. 42: 306m310.

(318) Mason, A. C., and Chisholm, ‥ D.

1949. An ethylene dibromido-chlordan mixture to control soilinhobiting stages of the Japanese beetle. Jour. Econ. Ent. 42: 639-542.

(319) Maswell, C.W. B.

1948. Control of the stramberry weev11, Anthonomus stenatus. Ent. Soc. Ontario Ann. Rpt. (1947) 78: 52-56.

(320) Meder, J. T., and Chamberlin, T. R.

1948. Seed ylelds of red and Ladizo clovers increased by u.se of insect1cidas. Jour. Econ. Int. 41: 108-109.

(321) -... and Chamberlin, T. R.

1949. Low pressure spraying equipment for control of some forage Insect. Jour. Icon. Int. 42: 239-243.

(322) Motcalf, B. I.

1947. Relat1ve toxicities of 1someric hexachlorocyclohexanes and related material to thrips. Jour. Bcon. Bnt. 40: $522-525$.

(323)

1948. Insecticidal activity of 2,2-b1s-(2-chlorothiengl)-1,1,1trichlor oothano. Science 108: 84-85.

(324)

1948. Acariclial propert1es of organic compounds related to DDT. Jour. Econ, Bnt. 41: 875-382.

(325) -...- Carlson, R. 3., and Murphy, U. E.

1948. Derelopment of new pest-control insecticides. Citrus Ieavos 28(9): 8-9; Cal1f. Citrograph 33: 522, 538.

(326) Michelbacher, A. E.

1948. Possible effects of new insecticides used in mosquito control on economic entomology. Callf. Mosquito Control Assoc. Proc. \& Papers 1948: 20-22. 
(327) Michelbocher, A. B., and Middlekauf, H. M.

1949. Codling moth 10reattgations on the Payno rartety of English walmet in Nortbern Celifcrnia. Jour. Icon. Int. 42: 736-7L6.

(323) Missoirl Apricuitural Fxtens1on Sarv1ce

1947. Spraylag suggestlons for commarcla? applg orchards, 1947. Mo. Col. Agr. Exton. Serr. Cir. 540, 16 pp.

(329)

1948. Spraying suggetions for comarclal applo or charda, 1948. Mo. Col. Agr. ExtGn. Serr. Cir. 553, 12 pp.

(330) M1tchener, 1. $\nabla$.

1949. Clalorinatod campeno, cblordan, DDT, and calclum arsenate compared for control of the Colorado potato bette. Jour. Econ. Ent. 42: 152-153.

(331) Montana State College

1949. Recomrendat1ons for the use and quidance of alreraft operators in the applicetion of sprav and dust for the control of insects, roeds, and plant diserses. Hont. Agr. Col. Fit. Pub., 13 pp. [Procossed.]'

(332) Morett1, G.

1948. Tossicita d1 alcunl composti clorurat1 per gli adult1 di Oryzaeghilus surinamensfs L. (Coleoptera - Cucrjidao). Soc. Ent. Ital. Bul. 78: 4-10.

(333) Morrison, H. E., Crowell, E. E., Crumb, S. I., Ir., and Lauderdale, R. W.

1948. The effects of certain new soll insecticlder on plants. Jour. Econ. Bnt. 41: 374-378.

(334) Mosna, E.

1948. Resistance of Culox giplens antogenicus to DDT and control with Octa-Flor and bexichloroczclohexano. Ist. Super d1 San1t. Rend. 11: 425-432.

(335) Funs, .., and Hixson, E.

1949. Effects of weather, anitation and chlor1nated chemical residues on house and stable fly populations on Tebrasta farms. Jour. Econ. Int. 42: 231-238.

(336) _... and Spencer, W. T.

1948. Dog maner control tests with chlorinated chenicals. Amar. Vet. Mod. Assoc. Jour. 113: 167-168.

(337) Munro, J. A., Nostdahl, W., and Bngel, B.

1948. Baits and dusts tested rgainst grasshopoers and crickets. 17. Dak. Adr. Expt. Sta. Binanthis Bul. 11(1): 11 . 
(338) Munro, J. A., Nostdahl, W., and Post, R. L.

1949. Wheat stem sawfly. N. Dak. Agr. Bxpt. Sta. Bimonthly Bul. 11(3): 85-91.

(339) - and Post, R. I.

1949. Control of boxelelder bugs. Jour. Bcon. Int. 42: 994.

(340) -... Post, R. I., and Hoyman, W. G.

1947. Iffect of Insecticides on tuber yield and control recommendations for 1947. N. Dak. Agr. Expt. Sta. Bimonthly Bul. 9: 109-110.

(341) Marphy, W. J.

1947. What's in a name? Chem. and Engin. News 25: 2253.

(342) Hagasava, $\mathrm{S}$.

1949. Comparison of the toxicity of gamma-BHC, 1068, and p, p'DDI to the pupa of the comon house mosquito. (In Japanesa) Botye-Kagakr 11: 20-23.

(343) Noiswander, B. B.

1949. The grape mealybug on Tarke in Oh10. Jour. Econ. Ent. 42: $41-44$.

(344) Nettles, Y. C., and Lewis, J. M.

1949. Wew Insecticides for insect control on flue cured tobacco. Clemson Agr. Col. Ext. Serv. Cir. 328, 8 pp.

(345) Newcomer, J. J.

1948. Fraluation of materials for controlling orchard mites and the woolly apple aphid. Wash. State Hort. Assoc. Proc. (1947) 43: 19-23.

(346) -... and Dean, F. P.

1948. Studies of or chard acaricides. Jour. Econ. Ent. 41: $691-594$.

(347) Nersom, L. D., Roussel, J. S., and Smith, C. E.

1948. Cotton insect studies. Several organic chemicals show promise as cotton insect poisons. La. Agr. Ixpt. Sta. Ann. Rpt. 1946-1947: 52-53.

(348) -... and Smith, C. E.

1949. Thrips as pests of seedling cotton. La. Agr. Expt. Sta. Ann. Rpt. 1947-1948: 68-69.

(349) -...- Smith, C. E., Clower, D. F., and Pfrimer, T. F. 1949. Chlorinated insecticides are more destructive to beneficlal insects than calcium arsenate-nicotino. La. Agr. Ixpt. Sta. Ann. Rpt. 1947-1948: 68. 
(350) Howsom, L. D., Smith, C. E., Pfrlmmer, T. F., and Clover, D. F. 1949. Comparison of sereral insecticides for control of cotton postg. La. Agr. Expt. Sta. Ann. Bpt. 1947-1948; 66.

(351) N1ckels, C. B.

1949. DDT and other insect1c1des to control the pecan mat case-bearer. Jour. Bcon. Ent. 42: 357-359.

(352) \$1swander, B. E., and Dar1dson, B. H.

1948. A comparison of the toxicity of some new insecticides to the German roach. Jour. Econ. Ent. 41: 652-653.

(353) Borth Carolina Agricultural Experiment Station

1948. Soll treatments prove effective on wireworms. Sorth

Carolina Agr. Expt. Sta. Ann. Bpt. 70 (1947):

Besearch and Farming 6(3): 10.

(354) Osburn, M. B.

1948. Compar1son of DDT, chlordane, and chlorinated camphone for control of the little fire ant. Fla. Ent. 31(I): $11-15$.

(355) Palumbo, M.

1949. Color reaction to 1dent1fy and determine Octa Klor

(clordan). Farm. sc1. e tec. (Pav1a) 4: 531-535.

(356) Parker, J. B.

1947. Comments and suggestions on locust control in Argentina. U. S. Bur. Ent. and Plant Quar. E-734. $14 \mathrm{pp}$. [Processed.]

(357)

1949. Tests of 1nsecticldes for grassbopper control, 1947. J. S. Bur. Ent. and Plant Quar. E-774, $18 \mathrm{pp}$. [Processed.]

(358) -.... and Wakeland, C.

1948. Hew insect1c1des for grasshopper cantrol. ர. S. Bur. Ent. and Plant Quar. EC-1, 7 pp. [Procossed.]

(359) Patriss1, T., Barbior1, .., and Bessler, C.

1949. DDT resistance of Mesca domestica and the use of other insecticides. R1T. malariol. 28: 137-151.

(360) Pederson, C. I.

1948. Insect1c1des 1ncrease legume seod. Mich. Agr. Expt. Sta. Q. Bur. 30: 298-308.

(361) -... and Sherman, F., III

1948. Fleld application to control spitlo bug in Michlean. Jour. Econ. Ent. 41: 659-661. 
(362) Pepper, B. B.

1947. Tests indicate chlordane may control onion thrips. Down to Earth. [Dow Chemical Co.] 3(3): 15.

(363) Potty, B. K.

1948. Laboratory experiments with new organic insecticides. Farming in South Africa 23: 325-332.

(364)

1948. Further laboratory studies with new organic insecticides. Farming in South Africa 23: 391-397.

(365)

1948. Residual toxicity of chlorinated hydrocarbon insecticides. Union So. Africa Dept. Agr., Sci. Bur. No. 291 (Ent. Ser. No. 27), $15 \mathrm{pp}$.

(366) Pimentel, D., and Dewey, J. E.

1950. Laboratory tests with house flies and house fly larvae resistant to DDT. Jour. Econ. Int. 43: 105.

(367) -...- Schwardt, H. H., and Norton, I. B. 1950. House fly control in dairy barns. Jour. Econ. Ent. 43: $510-515$.

(368) Plumer, C. C., and Shaw, J.G.

1947. Toxicants in oils for control of the citrus blackily. Jour. Econ. Ent. 40: 499-504.

(369) Post, G.

1949. Two new insecticides; the present knowledge of the effect of toxaphene and chlordane on game birds of Wyoming. Wyoming Wild Iife 13(4): 8-13, 37-38.

(370) Post, R. I., Colberg, W. J., and Munro, J. A. 1948. Effect of insecticides on tuber yield. N. Dak. Agr. Expt. Sta. Bimonthly Bul. 10(3): 98-100.

(371) --.- Munro, J. A., and Colberg, W. J. 1947. DDT more ffective than chlordane in control of weevils on peas. N. Dak. Agr. Expt. Sta. 1947 Ann. Ent. Progress Rpt. 1 p. [Processed.]

(372) Powell, D., Chondler, S. C., and Kelley, V. W. 1948. Pest control in commercial fruit plantings. Univ. IIl. Col. Agr. Ext. Serv. Cir. 623, 40 pp.

(373) -.... Chandler, S. C., and Kelley, V.W. 1950. Pest control in commercial fruit plantings for 1950. Unir. IIl. Col. Agr. Ext. Serv. Cir. 653; 40 pp. 
(374) Pritchard, A. E., Boer, R. E., and Rosenste1l, R. G. 1949. The omivorous leaf tier on field-rown cut flowers in Callforn1a. Jour. Econ. Ent. 42. 845-846.

(375) Purdue University Agricultural Extension Service

1948. Spray and dust ochedules for Indlana frults. Purdue Univ. Ert. Bul. 310 (3rd. Rev.), 30 pp.

$(376)$

1949. Spray and dust schedules for commercial fruit plent1ng. Purdue Unir. Ext. Bul. 310, 35 pp.

(377) -

1949. Grasshopper 8 and their control. Purcue Univ. Ent. Mimeo. Bnis (rev.), 2 pp.

(378)

1950. Indiana spray and dust schedules for comercial fruit plantings. Purciue Univ. Ext. Bur. 310, 48 pp.

(379) Putnam, L. G.

1948. Sprays and duste for grasshopper control. Canad. Sc1. Serv. Liv. Ent. Processed Pub. 73, 4 pp.

(380) Quarterman, K. D.

1948. Sore factors influencing the residual effectiveness of DDT and chlordane in anopheline mosquito control. liatI. Malaria Soc. Jour. 7: 300-306.

(381) Radeleff, B. D.

1948. Chlordane polsoning: symptomatolog and patholog. Vet. Med. 43: $342-347$.

(382) Bagsdale, E.

1948. Disease and 1nsect control on vegetable crops. Goorgla Agr. Ext. Serv. 2 pp.

(383) Rainwater, C. F.

1947. Some insecticldes causing boll weevil mortality inside of punctured cotton squares. Jour. Econ. Ent. 40: $023-0,25$.

(384) Raucourt, M.

1949. Actral1t1e日 piytopharmacout1ques; nouveaux insecticldes organ1ques de synthese. Rev. Hort. [Par1s] 121; 48-49.

(385) -...- and $\nabla$ iel

1948. Evaluation do la valour insect1cide do quelques corposes organiques de synthese. Acad. d'Acr. de France Compt. Rendt. 34: 328-330. 
(386) Rawlins, W. A., Staples, R., and Davis, A. C.

1949. Wireworn control with several insect1cides introduced into the so1l. Jour. Econ. Int. 42: 326-329.

(387) Reid, W. J., Jr., and Cathbert, F.P., Jr. 1949. Field-plot comparisons of DDT and other new materials for control of caterpillars on cabbage. U. S. Bur. Ent. and Plant Quar. E-787, 17 pp. [Processed.]

(388) Rhoades, W. C., and Brett, C. H.

1948. The relation of temperature in tho susceptibility of grasshoppers to synthetic insecticide dusts. Kans. Ent. Soc. Jour. 21: 66-70.

(389) Riemschneider, R., and Kahnl, A.

1948. Vorlauf1ge Mitteilung uber neue Kontakt-Insektizide der Halogenkohlenwasserstoffklasse. Pharmazie 3: 115-116.

(390) Biherd, P. T.

1948. Results of tests made with some newer insecticides for the control of the red harvester ant, Pogonomirmex barbatup (F. Smith). Fla. Bnt. 31(3): 68-70.

(391)

1949. Chlorinated insecticides for control of cowpea insects. Jour. Bcon. Bnt. 42: 991-992.

(392) Rings, R. $H$.

1949. Red-banded leaf roller injury to peachos and plums. Jour. Icon. Sint. 42: 701-702.

(393)

1950. Residual action of organic insecticides against plum curculio. Jour. Icon. Int. 43: 70-72.

(394) Ristich, S. S., and Schwardt, H. H.

1949. Biology and control of the seed-corn maggot on beans in Hew Yark. Jour. Econ. Int. 42: 77-80.

(395) Ritcher, P. 0.

1948. Insects injuring strawberries. Ky. Agr. Expt. Sta. Kentack Frust Notes 3(6): 6-7.

(396)

1949. How mterials for control of strawberry crown borer. Jour. Icon. Ent. 42: 838-839.

(397) - _- and Armstrong, W. D.

1948. Bxperience with curculio in Kentrcky. Ind. Hort. Soc. Trans. (1947) 87: 16-21. 
(398) Bomano, $\mathbf{E}$.

1950. Chlordan determinat1on. Ann. Sper. (Roxar. 4: 295-306.

(399) Rosenst1el, H. G.

1949. I1fe history ard coutrol of the orange tortrix in Oregoa. Jour. Icon. Int. 42: 37-40.

(400) Roth, A. R., Yater, W. K., and Indquit, A. W.

1947. Prellminary studies of larvic1des on snow-kater rosquitoes. Mosquito Hews $7(4): 154-156$.

(401) Russe11, E. E.

1949. Tests with DDT, chlordane, toxaphene, and benzene kezachloride for control of Iyrrs spp. on seed alfalfa in southern arizona, 1945-1948. U. S. Bur. Int. and Plant Quar. E-788, 13 pp. [Processed.]

(402) Sarage, I. I., and Cowart, F. F.

1948. Roport of the 1948 spraping experixents for the control of plum curcul1o on juaches. Goorg1a Expt. Sta. Press Bur. 598, Arg. 9, 1948. 7 pp. [Processed.]

(403) Scaleg, A. I. and Sn1th, G. I.

1948. Cage testa agalnst the boll weorll and the tarnished p'ant bug with synthetic organic insecticides and calclum arsenate in 1947. Jour. Econ. Int. 41: 403-405.

(404) Schmitt, J. B.

1947. A recomended care of the ant problem. Pests 15(10): 50,52 .

(405) Schread, J. C.

1948. Control of the Japanese beetle. Conn. Agr. Expt. Sta. C1r. 166, $8 \mathrm{pp}$.

(406)

1948. Control of so11 insects. Jour. Econ. Ent. 41: 318-324.

(407)

1948. Japanese betlo control. Conn. Aer. Expt. Sta. Spec. Bul. Int. 33, I p. [Processec.]

(408)

1949. Chinch buf control in 1awns. Conn. Agr. Expt. Sta. C1r. $168,6 \mathrm{pp}$. 
(409) Schread, J. C.

1949. Residual activity of insecticides in control of turf insects. Jour. Econ. Ent. 42: 383-387.

(410)

1949. A new chlorinated insecticide for control of turfinkabiting insects. Jour. Econ. Ent. 42: 499-502.

(411) (....

1950. Control of the strawberry root weevil in nursery plantings. Conn. Agr. Expt. Sta. Cir. 174. $8 \mathrm{pp}$.

(412) -..- and Chapman, G. C.

1948. Control of ants in turf and soil. Conn. Agr. Expt. Sta. Bur. 515, $23 \mathrm{pp}$.

(413) Severin, H. C.

1946. Injurious gresshoppers. S. Dak. Agr. Expt. Sta. Ann. Bpt. 59 (1945-1946): 16-17.

(414)

1947. Experiments in grasshopper control. S. Dak. Agr. Hxpt. Sta. Ann. Rpt. 60 (1946-1947): 15-17.

(415) - 1948. Crop insects. S. Dak. Agr. Expt. Sta. Ann. Rpt. 61 $(1947-19,48): 23-25$.

(416)

1948. [Grasshopper control]. S. Dak. Agr. Expt. Str. Ann. Bpt. 62 (1948-1949): 30-32.

(417) Shelford, $\nabla$. E.

1949. Termite treatment with aqueous solution of chlordan. Jour. Econ. Int. 42: 541.

(418) - 1950. Termite treatment with aqueous solution of chlordane. Jour. Econ. Ent. 43: 107.

(419) Shotwell, R. I.

1949. The comparative effectiveness of poisoned bait and sprays for grasshopper control in Iyman County, $S$. Dak., 1947. U. S. Bur. Bint. and Plant Quar. Bm.77. 22 pp. [Processed.]

(420) Smith, C. F., Jones, I. D., and Rigney, J. A.

1949. Effect of insecticides on the flavar of peaches - 1948. Jour. Econ. Ent. 42: 618-623. 
(421) Sm1th, C.I.

1948. Chlorinated hydrocarbon insecticides for control of the horn My on dairy cattle in Texas. Jour. Icon. Int. 41: $981-982$.

(422) Sm1th, C. N., and Gouck, E. K.

1947. The control of chlggers in woodland plote. Jour. Econ. Ent. 40: 790-795.

(423) Sm1th, I. F.

1948. DDI and other synthetics for control of gladiolus thripe. Jowr. Bcon. Ent. 41: 955-959.

(424) -... and Boswell, A. I.

1948. Iffective control of gladiolus thrips with never mater1als. Florist's Beriew. Apr. 1. 102(26-27): 29-30.

(425) Sm1th, G. I.

1948. Cal1fornia cotton insects. Cal1f. AgI. [Cal1f. Sta.] $2(4): 16-17$.

(426) Sm1th, B. R., and Kenzel, M. R.

1947. So11 microortenisms are affected by some of the now

insect1c1der. Soll Sc1. Soc. Am. Proc. 12: 227-233.

(427) Smith, B. I., and Allon, W. W.

1949. Chemical control of the alfalfa caterpillar in California. Jour. Bcon. Rent. 42: 487-495.

(428) Snapp, 0.I.

1948. How insect1cides for control of plum carcalio on peach. Jour. Icon. Int. 41: 569-574.

(429)

1949. Hew insecticides for plum curculio control - Second report. Jovr. Econ. Ent. 42: 7-11.

(430) Somsen, H. K., and Munro, J. A.

1947. Chlordano in roach control. N. Dak. Agr. Expt. Sta. 1947 Ann. Int. Progress Rpt., I p. [Processed.]

(431) South Carolina Agricultural Brperiment Station

1949. Cotton production and insect control, Soutb Carol1na, 1949. Clemson Agr. Col. Ext. Serv. Cir. 324, 7 pp.

(432) Sparks, I. M.

1948. Farmer experiences and result in controlling cotton Insects by polsoning in South Carolina during 1948. Clemson Ap. Col. Ext. Sert., 28 pp. [Procensed.] 
(433) Spencer, W. T.

1948. Sarcoptic swine mange control tests with chlordane. Amer. Vet. Med. Assoc. Jour. 113: 153.

(434)

1948. The I170 Stock Sanitary and Loss Prevention Board of the Omaha Live Stock Market Interest8. 27th Ann. Bpt. 14 pp. [Processed.]

(435)

1948. Sarcoptic swine mange. Norden News 22(4): 4.

(436) Stafford, E. M.

1949. Control of olive scale in Californla with parathion, Jour. Bcon. Int. 42: 656-660.

(437) Stahnike, H. I.

1948. Scorplons. Arizona State Col. Gen. Series Bul, 71, 16 pp.

(438) Steiner, I. F., Strmerland, S. A., McAlister, H. J., and Faher, J.I. 1948. Studies of new insecticides for control of apple insects. Ind. Hort. Soc. Trans. (1947) 87: 29-46.

(439) Stiles, C. F., and Fenton, F.A.

1948. Comparative effectiveness of various insecticides and methods for controlling cotton insects. Okla. dgr. Expt. Sta. Cir. C-126, 4 pp.

(440) Stitt, I. I., and Eide, P. M.

1948. Jex insecticides for cabbage maggot control in Western Nashington. Jour. Econ. Ent. 41: 865-869.

(44I) -... and Iranson, J.

1949. Phytotoxicity and off-quality of regetables grown in soil treated with insecticides. Jour. Iicon. Int. 42: 614617.

(442) Stohlman, I. F., and Smith, M. I.

1950. Toxicological action and metabolic fate of chlordan. Adrances in Chem. Series I: 228-23I.

(443) -... Thorp, W. T. S., and Smith, M. I.

1950. Toxic action of chlordan. Arch. Indus. Hyg. Occupational Med. 1: 13-19.

(444) Stringer, A.

1949. A simple method for assajing contact toricities of insecticldes, with results of tosts of some organic compounds against Calandra ranaria L. Ann. Appl. Biol. 36: $213-224$. 
(445) Sun, Yun-Pe1

1948. Synergistic action of chlordan in dusts containing nicotine or rotenone. Jour. Econ. Ent. 41: 89-91.

(446) (-...

1948. Chlordene - studies on 1ts phys1cal, chentcal, and insect1c1dal properties, Part I, 77 pp.; Part II, 81 pp. Dept. Ent. Bow York State Col. Agr. [Procossed.]

(447) - - -

1950. Toxdc1ty 1nder - an 1mproved method of compering the relative toxicity of insecticides. Jour. Econ. Int. 43: $45-53$.

(448) -... Norton, I. B., and Rawlins, W. A.

1948. Comparison of toxic actions of cklordan, DDT, and gamabenzene hexachloride to the southern armyorm. Jour. Econ. Eint. 41: 366-369.

(449) -- Norton, L. B., and Rawlins, W. A.

1948. Factors affecting toxicity in formulating chlordan emul sions. Jour. Econ. Ent. 41: 751-755.

(450) --.- Rawlins, W. A., and Norton, I. B.

1948. Comparative toxicity of chlordan, DDI, benzene hexachloride and chlorinated cempheno. Jour. Econ. Int. 41: 91-97.

(451) Sreetman, H. L.

1947. New organic 1nsect1c1des to control hog lıce. Jour. Econ. Int. 40: 454-455.

(452) Tarzwell, C. M.

1950. Effects on fishes of the routine manual and alrplane application of DDT and other mosquito larvicidos. U. S. Public Bealth Bpt 8. 65: 231-255.

(453) Telford, H. S.

1947. Insect1cides far cattle grub control. Jour. Econ. Int. 40: $928-930$.

(454) Thompson, W. I., and Griffiths, J. T.

1947. New 1nsecticides and their application on citrus. Fla.

State Hort. Soc. Proc. (1947) 60: 86-90. Also in C1trus Indus. 29(3): 4, 10 .

(455) T1bbetts, T., and Sorenson, C. J.

1949. Dipp1re Gives better control of shoep t1cks than dusting.

Farm and Home Sc1., Utah AEr. Rrpt. Sta. 10: 14-16. 
(456) Tissot, A. N., and Kuitert, I. C. 1948. Insecticide tests for the control of fall armyworm on corn. Fla. Ent. 31: 105-112.

(457) Toffalet1, J.P. 1950. Iindano. Pest Control 18(4): 24, 26.

(458) Travis, B. $\nabla$. 1949. Studies of mosquito and other biting-insect problems in Alaska. Jour. Econ. Ent. 42: 451-457.

(459) -..- Gjullin, C. M., Blanton, F. S., Smith, N., and Wilson, C. S. 1949. Prehatching treatments for the control of Aedes in Alaska. Mosquito News 9: $42-48$.

(460) Turk, R. D., and Batte, E. G. 1948. Chlordane in the control of external parasites of dogs and cats. North Amer. Vet. 29: 359-360.

(461) Turner, $\mathbb{1}$.

1949. Control of insects on tobacco. Conn. Agr. Expt. Sta. C1r. 167. 4 pp.

(462) -... and Woodruff, N.

1948. Chlorinated insecticides for control of the potato flea beetle. Jour. Econ. Ent. 41: 328-329.

(463) - -

1949. Effect of formulations of DDT, and of chlordan on potato flea beetles and yleld. Jour. Econ. Ent. 42: 470-473.

(464) United States Bureau of Animal Industry

1948. Report of the Chief of the Bureau of Animal Industry, Agricultural Research Administration, 1948. 104 pp.

(465)

1949. Report of the Chief of the Bureau of Animal Industry, Agricultural Research Administration, 1949. 97 pp.

(466) United States Burean of Entomology and Plant Quarantine 1947. Conference report on cotton insect control, Stoneville, Miss., Nov. 17-19, 1947. 16 pp. [Processed.]

(467)

1948. Conference report on cotton insect research and control, Baton Rouge, Louislana, Nor. 8-10, 1948. 26 pp. [Processed.] 
(468) Untted States Burear of Intomology and Plant Quarantine 1949. The new 1nsect1c1des for controlling external parasites of I1vestock. O. S. Bur. Int. and Plant Quar. 3-752. (rer.), 25 pp. [Processed.]

$(469)$

1949. Japanese beetle. P1cture Sbeet Io. 4, (rer.) May.

(470) 1949. Controll1ng the Japanese bestle. O. S. Dopt. Ag. Farmers' Bul. 2004, 14 pp.

(471) - 1949. Brief recommendations for ant control. I p. [Processed.]

(472)

1949. Brief recomendations for roach control. $1 \mathrm{p}$. [Processed.]

(473) Unted States Department of Agriculture Exteng1on Service 1948. Report of Reglonal Conference on l1restock and crop pest control, Chlcago, III. June 24-26. 24 pp.

(474) Untted States Production and Marketing Administration

1949. Not1ce to manufacturers, registrants, and d1stributors of insect1c1des contalning clalordane. U. S. Production and Marketing Adm. Ilvestocik Branch, Insect1c1de D1v. Leaflet, 1 p. May 12.

(475) Velsicol Corporation

1946. Methode de preparation d'une nouvelle composition de matiere et prodult obtenu par cette methode. Belg1an Patent No. 463,631; applled for Mar. 5, 1946.

$(476)$

1947. Perfectlonnements relat1fs a un procede do fabrication d'une nouvelle composition et prodult resultant. French Patent No. 926,593: appl1ed for Mar. 1, 1946; publ1shed Oct. 5, 1947.

(477) 1947. Neuros 1ngect1c1des constitudos por herahaloc1clopentadieno condensado con un componente dienlco. Argentine Patent No. 61,656, Nor. 18.

(478)

1950. Spec1f1cat1ons - techn1cal chlardano - Vels1col 1068. Form 93, 2 pp. ApriI 1950. 
(479) Velsicol Corporation

1950. Detection and determination of heptachlor. Velsicol Corp., Chicago. $10 \mathrm{pp}$. Aug. 15. [Processed.]

(480) Wakeland, C., and Parker, J.R.

1949. Grasshopper control improved by new insecticides. U.S. Bur. Fnt. and Plant Quar. $\mathrm{HC}-7,8 \mathrm{pp}$. [Processed.]

(481) _- and Parker, J. B.

1950. Chlordane and toxaphene for grasshopper control. U.S. Bur. Int. and Plant Quar. FC-11, 10 pp.

(482) Walker, B. L., Fife, L. C., and Bondy, F. F.

1949. Comparative effectiveness of chlorinated hydrocarbons againgt the boll veevil. Jour. Bcon. Int. 42: 685-686.

(483) WaIton, R. R.

1947. Iffects of chlorinated hydrocarbons and sabadilla on insects and plants. Jour. Bcon. Bnt. 40: 389-395.

(484) Veaver, N.

1949. The toxicity of certaln organic insecticides to honoybeos. Jour. Icon. That. 42: 973-975.

(485) Weining, R. M., and Hoerner, J.I.

1947. Grasshopper control with dusts and sprays for protection of experimental plots. Am. Soc. Agronony Jour. 39: $346-348$.

(486) Weinman, C. J.

1947. Insecticide tests on codling moth in Illinois, 1946. Jour. Jicon. Rnt. 40: 567-568.

(487)

1948. Peach insect problems. Ind. Hort. Soc. Trans. (1947) 87: $21-25$.

(488) - -.. and Decker, G. C.

1947. An analysis of certain factors relating to control of grasshoppers with some chlorinated hydrocaron insecticides. Jour. Econ. Bnt. 40: 84-90.

(489) -.. and Decker, G. C.

1949. Chlorinated hydrocarbon insecticides used alone and in combinations for asshopper control. Jour. Econ. Int. 42: 135-142.

(490) - Deciker, G. C., and Blgger, J. H.

1947. Insecticidal sprays and dusts for control of grasshoppers. Jour. Hcon. Int. 40: 91-97. 
(491) Welch, H.

1948. Tests of the toxic1ty to sheop and cattle of certain of the newer insect1cides. Jour. Econ. Ent. 41: 36́-39.

(492) Wene, G. P.

1948. Control of the cowpea curcul10. Jour. Econ. Ent. 41: $514-515$.

1949. Control of the cowper curcul10. Jour. Econ. Ent. 42: $856-357$.

(494) 1949. Control of the suciefly on tomato. Jour. Econ. Int. 42: 983.

(495) _-.. and Blanchard, R. A.

1950. Insecticide dust for control of the corn earworm. Jour. Econ. Ent. 43: 1-4.

(496) Kest, T. F.

1946. "Velsicol 1068". Nature [London] 158: 951.

(497) Wilson, C. D.

1948. Research on new 1nsecticldes for grasshopper control. cal1f. Dept. Agr. Bul. 37: 95-101.

(498) Wilson, H. G., and Gahan, J. B.

1948. Susceptibility of DDT-resistant houseflies to other insecticidal sprays. Science 107: 276-277.

(499) W1lson, J. W., Kelshelmer, E. G., Griffitios, J. T., and T1ssot, A.N.

1948. A prellminary report on the control of the green peach aphid on shade grown tobacco in Florida. Fla. Ent. $30(4): 45-45$.

(500) W1Ison, M. C.

1949. Organic insecticides to control alfalfa insects. Jour. Econ. Ent. 42: 496 +98.

(501) Wingo, C. W., Jenkins, L., and Murneek, A. E. 1946. "I068" for grasshopper control. Hort. News (Missouri State Hort. Soc.) 5(1I): 1-2.

(502) 1948. Development of the two-spotted spider mite in the presence of DDT and other 1nsecticides. Jour. Econ. Ent. 41: $688-591$. 
(503) Nisconsin, University of

1949. Insect control - recomendations for H1sconsin in 1949. Wis. Agr. Col. IIxt. C1r. 287, 14 pp. [Processed.]

(504) - 1946. Wew insecticides look good for notato nests. Wis. Onit. Agr. Exnt. Sta. Ann. Rnt. $63(1945-1946): 9,10,17$ (Bral.472)

(505) - 1948. Insect control recomendations for Wisconsin, 1948. Via. Agr. Col. Ext. Cir. 273, 10 pp. [Processed.]

(506) Woglum, R. S., Plumer, C. C., and Shaw, J. G. 1949. Insecticides for citrus blackfig. Calif. C1trograph 34: $146,177-180$.

(507) Wolfenbarger, D. 0.

1947. Tests of some newer insecticides for control of subtropical fruft and truck crop pests. Fla. Bnt. 29(4): $37-44$.

(508)

1947. The serpentine leaf miner and its control. Fla. Agr. Ixpt. Sta. Press Bul. 639, 6 pp.

(509) Woodard, G., Daridow, B., and Lehman, A. J.

1948. Metabolism of chlorinated hydrocarbon insecticides. Indus. and Engin. Chem. 40: 711-712.

(510) Hoodside, A. M.

1948. Tetraethyl pyrophospbate for control of the perlodical cicada. Jour. Bcon. Int. 41: 722-724.

(511) - -

1949. The tobacco stalk borer in western Mexico. Jour. Icon. Ent. 42: 63-67.

(512)

1949. Tests of insecticides for control of cat-facing on peaches. Jour. Econ. Int. 42: 335-338.

(513) Wressell, H. B.

1948. Insecticidal control of the Buropean corn borer (Byrausta nubilalis) in southwestern Ontario in 1947. Thnt. Soc. Ontario Ann. Rpt. (1947) 78: 10-14. 
(514) Wyl1e, W. D.

1948. Tests of nen 1nsect1cides for the control of aphids on celery in tho Ererglades. Fla. Agr. Expt. Sta. Bul. $446,28 \mathrm{pp}$.

(515) Zuniga, B., Coronado Padilla, B., and R1vera, M. 1947. Clordane y gammexano como acridicidas. Agricultura

[EI Salvador] 1(1): 13-17. 